Historic, Archive Document

Do not assume content reflects current scientific knowledge, policies, or practices. 



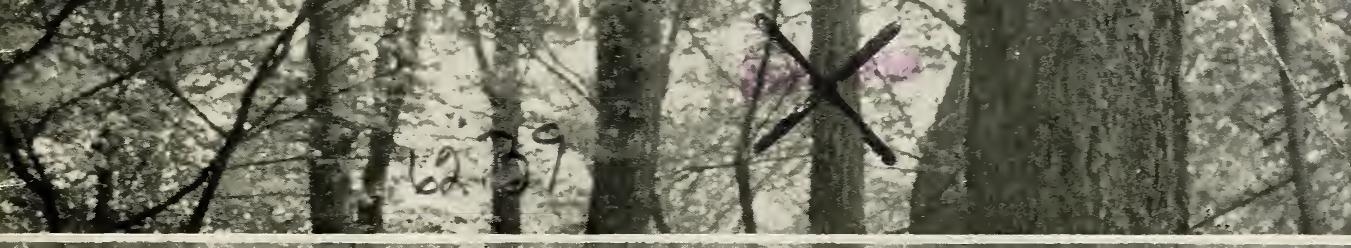

\section{Gulemt's lardor Feprand Flower Parey}

\section{Southunick, Nassochuseths}

\section{$1878-1927$}

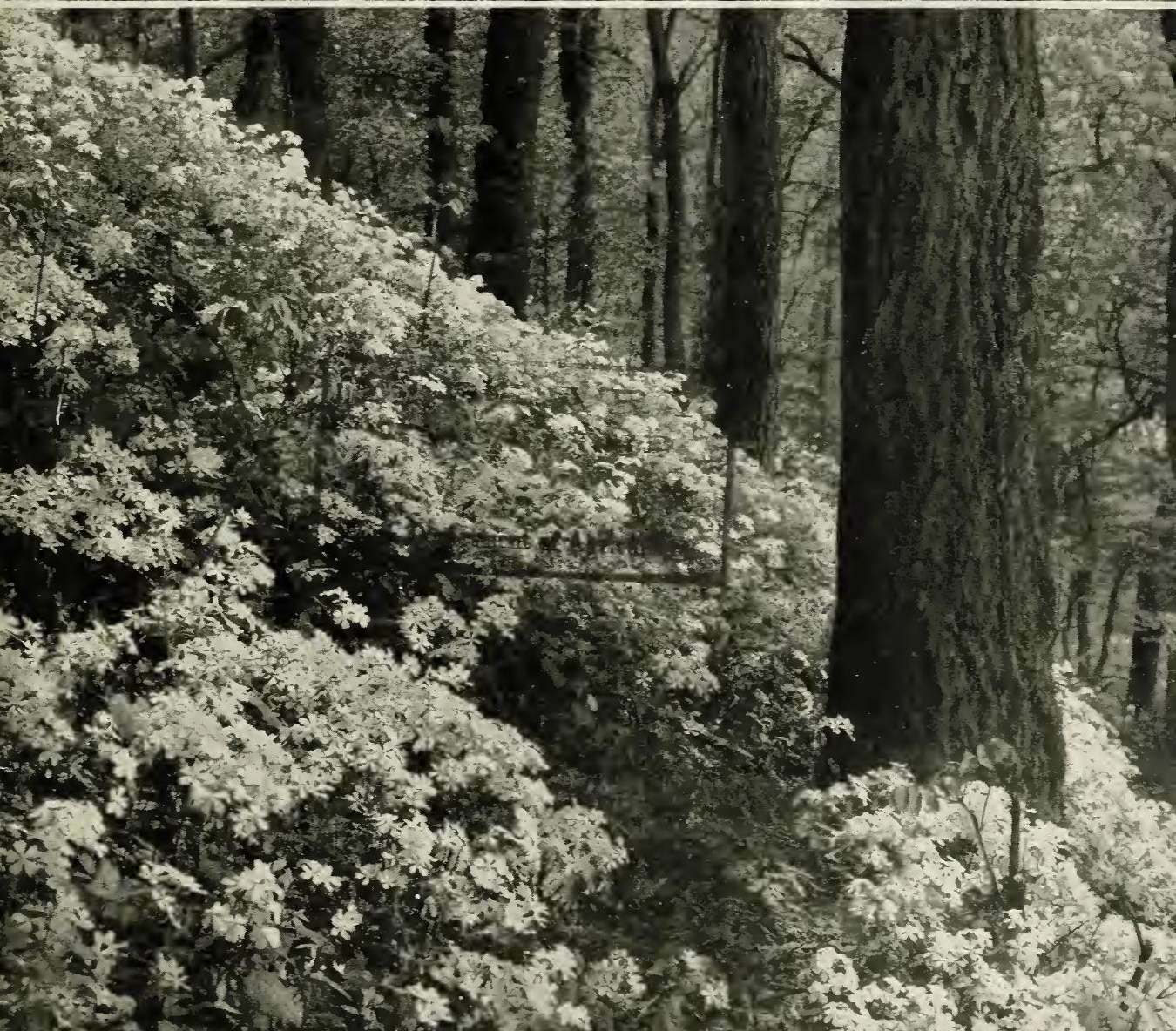

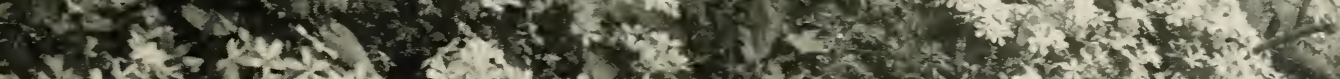
d 4hos

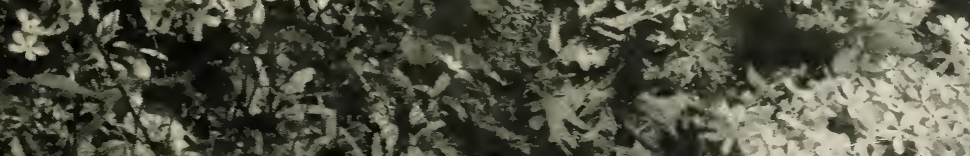




\section{A Message to Customers and Friends}

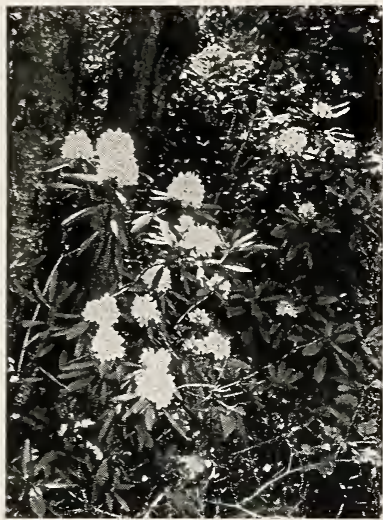

\section{PACKING}

This department is in charge of experts who use the utmost care in digging and packing all orders. I have always used sphagnum moss in wrapping plants; it is the very best material which can be procured. No matter whether an order is smaII or large, it always receives the same careful attention, and I can assure any prospective buyer that all orders will be packed properly. Throughout the season we receive numerous testimonials from our customers telling us of the excellent manner in which stock arrived, although in many cases delayed for a long time in transit. These testimonials we receive from all parts of the United States and even from foreign countries. Those who live at a considerable distance need have no fear about stock arriving in poor shape due to faulty packing.

\section{SHIPPING}

We always advise having herbaceous stock shipped by express and will make delivery by this method unless otherwise advised. Please give us definite instructions as to mode of transportation desired, giving routing where there is any preference; where no routing is given we will use our best judgment in making shipment but will not be held responsible for delays which may result from such action.

\section{PRICES}

Five of any one variety will be sold at the 10 rate; 30 of one variety will be sold at the 100 rate; 300 of one variety will be sold at the 1,000 rate, where the 1,000 rate is given.

Prices on ferns and herbaceous stock include packing and delivery to the local freight or express office. AIl prices are based on express or freight shipment. In case a customer desires to have stock shipped by parcel post, 10 per cent of the amount of the order should be added to cover delivery charges east of the Mississippi River, and 20 per cent on orders to points west of the Mississippi River.

AII evergreens and shrubs will be shipped by express or freight collect. The prices on evergreen trees, evergreen shrubs, and deciduous shrubs include all packing charges, and delivery to the local express or freight office.

\section{CLAIMS}

No claims will be entertained unless received within ten days after the receipt of the stock. While we use proper care in packing, we cannot be held responsible for undue delay in transit. We hold ourselves in readiness at all times to replace stock which arrives in poor order due to faulty packing.

\section{HOW TO REACH MY NURSERIES}

My nurseries are located at Southwick, Mass., on the Northampton Division of the New York, New Haven \& Hartford Railroad.' The New College Highway extending from Northampton to New Haven passes my nurseries, making them easily reached by automobile from all directions. Visitors are always welcome, and if prospective buyers will let me know a few days in advance I shall be glad to personally conduct them through my nurseries and assist them in making the selections they may require.

Most sincerely, 


\section{Hardy Ferns and Flowers}

EDWARD GILLETT, Southwick, Mass.

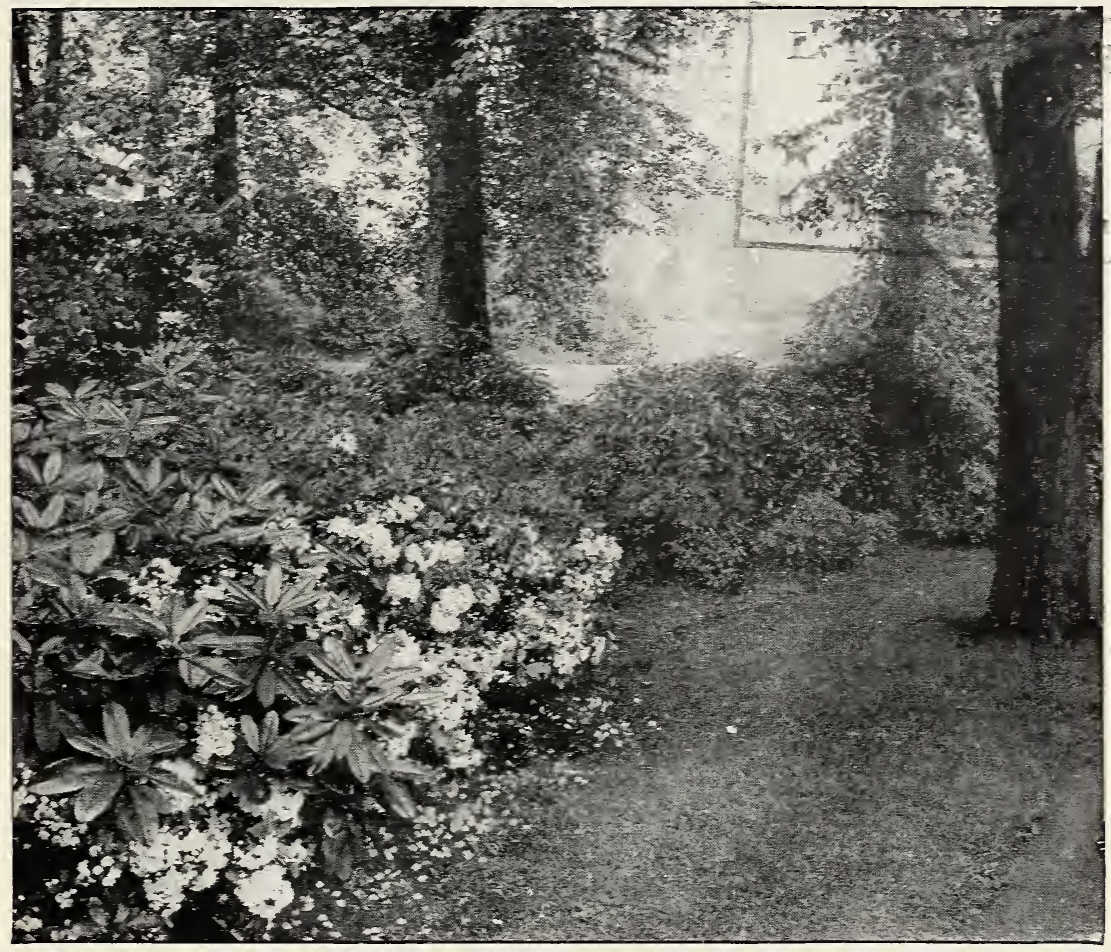

A woodland effect may easily be given to lawn borders by a careful selection of Rhododendrons and other broad-leaved evergreens and native shrubs and plants

\section{How to Select Plants for Special Places}

₹ AII plants desirable for growing in dark, shady places, shut out from the sunlight, are marked with this sign $¥$. Very few of the old garden plants will thrive in such a place, but most of the Hardy Ferns of New England, and several of the best wild flowers are at home here; the little nook by the porch, shut away from the sunlight, the deep shade of the great lawn tree, where even grass will not grow, the wooded bank, are all places to beautify with this class of plants.

- This sign means that the plant is adapted for the low, wet places where sedges crowd out the grasses, and bulrushes thrive; Lobelias, Marsh Marigolds, Iris, Sarracenias, Mentha, Lythrum, etc., find here a congenial home.

- AII the old garden plants, those to grow in beds or borders, like Campanulas, Aquilegias, those best suited for open, sunny places, desiring, for the most part, a moist, yet well-drained soil in the open sun, are marked $\diamond$.

* Plants marked with a are adapted for dry woods. Many of the Asters and Golden-rods will thrive here. Most of them come in late summer, when other flowers are passed; they do quite weIl, also, in dry, open places.

Occasionally will be seen two of the signs against the same plant; this means that the plant seems to do equally well in both positions. 


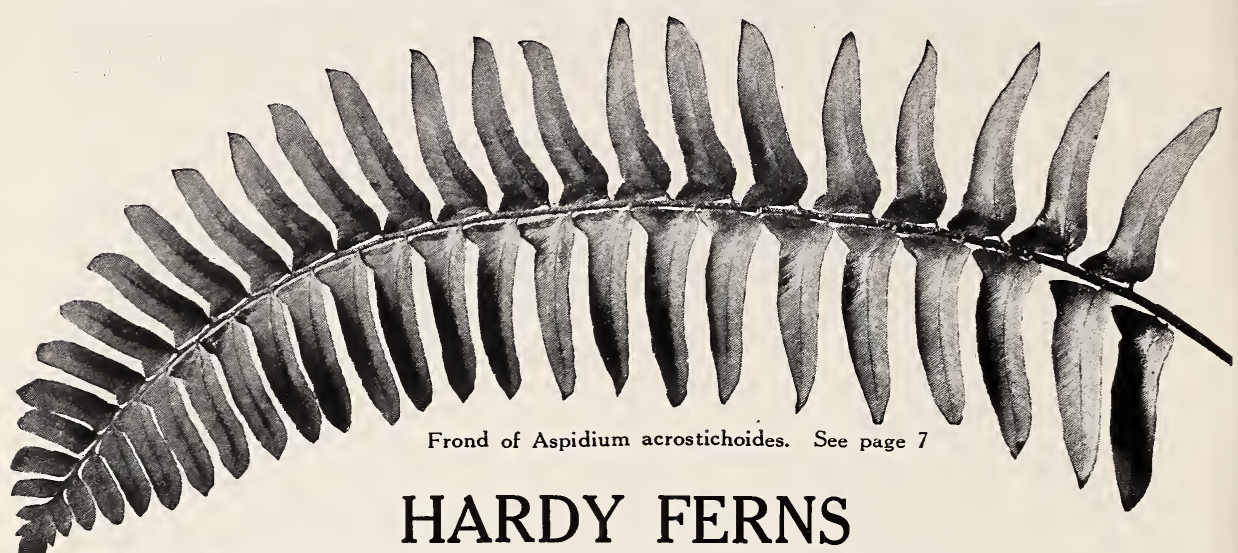

Hardy Ferns are being used in quantity for massed plantings, and selections can be made to suit almost any location. Many times there are corners about the house where the sun does not strike. Such places can be beautified by the use of Hardy Ferns. $\mathrm{My}$ Fern trade is extensive and I am in a position to furnish them in quantity and wiIl be glad to make special quotations on large amounts. I carry in stock over fifty varieties of hardy native Ferns most of them taking readily to cultivation. There are a few varieties of hardy native Ferns which will thrive in the open sun, yet, for the most part, they will give much better results when planted in a shady location. The Ferns I offer, being native, require a period of rest and consequently are not suitable for house culture in the winter.

Soils. Some of the Iarger-growing Ferns can be grown with extremely good results in ordinary garden soil in a shady location, yet, if we intend to imitate Nature, it will be necessary to furnish, for many of our Ferns, better conditions than are found in the ordinary garden. In planting Ferns it is well to prepare the soil by making it very fine, then adding, if practicable, leaf-mold so as to make the soil very light and porous. If the planter does not have at his disposal a sloping piece of ground and is anxious to have Ferns in his garden, it will be well to raise the bed 2 to 3 inches in which they are planted. This will tend to produce the drainage conditions necessary.

In planting the small rock Ferns, almost pure leaf-mold or peat should be used. This class of Ferns is, as a rule, found growing in such soils and while they can be made to struggle along and in some cases give fairly good results in ordinary garden soil, they will do much better if furnished the conditions as above described.

Uses. Our Hardy Ferns, being so varied in their characteristics, can be adapted to a wide variety of purposes. AII of them can be used as specimens in the Hardy Fern collection; many can be used for edging walks in a shaded rock-garden; while others are best suited for massed plantings.

Time to plant. Hardy Ferns can be planted in either the spring or faII. If they are planted late in the autumn it is well to give them a mulch of leaves. This gives them protection from freezing and thawing and it also tends to retain the moisture in the soil until the new rootlets have started to grow.

How deep to plant. Doubtless many amateurs are not successful in growing Ferns, due to the fact that they place them too deep in the ground. Those varieties, such as the Christmas Fern or Evergreen Wood Fern, which grow from a crown should not be planted below the surface; the crown should be left exposed to the air. In case Ferns grow from underground root-stalks, such as the Beech Fern, they should be planted just below the surface with not more than half an inch of earth to cover them. Too deep planting proves fatal, especially where a long, wet season follows the planting which causes the crowns or buds to rot.

ADIANTUM pedatum (Maidenhair Fern). The most gracef al of all our New England Ferns, attaining a height of from 12 to 18 inches when grown in rich, moist shady locations. It requires a well-drained situation, as is the case with most of our Ferns, but when once established it increases from year to year. It should be planted about an inch below the surface of the ground, the plants being placed 8 inches apart if a massed effect is desired. 
ASPIDIUM acrostichoides (Christmas Fern). $¥$ An evergreen species, about a foot high, with deep green fronds simply divided. Although it is one of our common species, it is a pretty one, and easily grown in shade, in good garden soil, well drained. A good Fern for planting with other sorts. Plant with the new crowns or buds just at the surface.

aculeatum Braunii (Prickly Shield Fern). $*$ This rare Fern has light, glossy green foliage and when grown in very rich soil attains a height of 12 to 15 inches. It is spreading in its habit, similar to the Christmas Fern. Plant a foot apart with the new crowns just above the surface. 40 cts. each, $\$ 3.50$ for $10, \$ 30$ per 100 .

cristatum (Crested Wood Fern). $\approx$ Grows in rather wet places, attaining a height of about a foot. Fine for lining walks through moist situations or planting in small colonies in shade. Easily grown, if the crown is set just above the surface of the ground.

cristatum Clintonianum. $*$ A large form of Cristatum, attaining a height of nearly 3 feet when grown in moist, rich places. Everoreen type especially desirable for the Fern-bed. To produce massed effects it should be planted a foot apart.

Filix-mas (Male Fern). * A rare evergreen type native to the Northwest. This variety grows 2 feet high in rich soil. The crowns should be planted just at the surface, a foot apart if massed effects are desired. 35 cts. each, $\$ 3$ for $10, \$ 25$ per 100 .

Goldieanum (Goldie's Wood Fern). $*$ When fully grown it attains a height of 3 feet, having dark green fronds in some cases more than a foot wide. Plant the crowns just above the surface, and, if massed effects are desired, a foot apart. $50 \mathrm{cts}$. each, $\$ 4.50$ for $10, \$ 40$ per 100 .

marginale (Evergreen Wood Fern). $*$ An evergreen variety having dark green fronds which are rather stiff in appearance. Used extensively for ground-covers under shrubbery. Plant the crowns just above the surface and one foot apart.

munitum (Giant Holly Fern). $¥$ An unusual Fern from Idaho and Washington to Alaska. Revels in mossy beds and abundant moisture in the dense shade. Footlong fronds, with long, narrow pinnæ. 35 cts. each, $\$ 3$ for 10.

noveboracense (New York Shield Fern). * This is a slender species growing a little over a foot high, the fronds being 3 to 4 inches wide. It gives best results when planted in moist, shady locations. Its pale green foliage contrasts beautifully with the darker colored varieties when planted in masses. The buds of this Fern should be planted just below the surface of the ground and, for massing, 9 inches apart. spinulosum (Spinulose Wood Fern). $*$ Requires well-drained locations and if grown in rich soil attains a height of $11 / 2$ to 2 feet. It is fine for massing under shrubs to form an evergreen ground-cover. The crowns should be planted just at the surface, and, for mass planting, a foot apart.

spinulosum dilatatum.

* This is similar to Spinulosum but has broader fronds. When grown in rich, moist situations it attains a height of $2 \frac{1}{2}$ feet. When planting, furnish it with rich, porous soil. Plant the crowns just at the surface, and $1 \frac{1}{2}$ feet apart for massing. 30 cts. each, \$2 for 10 , $\$ 15$ per 100 .

Thelypteris (Marsh Shield Fern). $\diamond$ A foot high, with fronds about $21 / 2$ inches wide. It can be cultivated in moist, open places, and, like all the ferns, is benefited by adding leaf-mold which makes the soil the plants like.

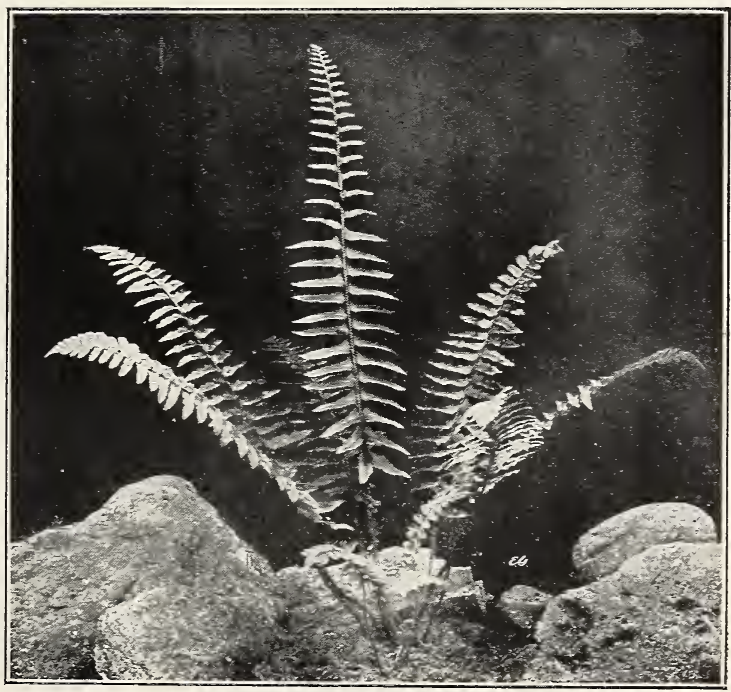

Aspidium acrostichoides

Prices on Ferns, 25 cts. each, $\$ 1.50$ for $10, \$ 12$ per 100 , unless otherwise noted 
ASPLENIUM angustifolium (Narrow-leaved Spleenwort). $⿴ 囗$ A charming Fern 1 to 3 feet high, with simply divided fronds 3 to 4 inches long. Its home is in rich, shaded places, where it is quite moist. 30 cts. each, $\$ 2.50$ for $10, \$ 20$ per 100 .

ebeneum (Ebony Spleenwort). \& 6 to 15 inches high. Suited for rockwork. In planting in the front border of Fern-beds, give it a little leaf-mold, and plant about 8 inches apart; do not cover the new buds.

Filix-fœmina (Lady Fern). $\diamond$ A large, handsome Fern, 2 to 3 feet high, with finely cut foliage. Plant in a moist place, in sun or shade, in good, rich soil. A good Fern to grow as single specimens, or it can be set $1 \frac{1}{2}$ to 2 feet apart at back of Fern-bed. One of the best for general culture.

Trichomanes (Maidenhair Spleenwort). 圈 A delicate little Fern, with narrow fronds 3 to 6 inches long. Although found up among the cliffs, it adapts itself to the small rockery, where it does exceedingly well, and also in the Fern border. This is one of the small evergreen Ferns benefited by a good allowance of leaf-mold. Plant about 8 inches apart, in colonies of a dozen or so if possible, with the crowns at the surface.

thelypteroides (Silvery Spleenwort). Fronds 2 to 3 feet high, by 6 inches wide. Thrives in moist shades. A good thrifty Fern, deserving of a place well back in the Fernbed. Any good garden soil. Plant 1 foot apart.

BOTRYCHIUM virginianum (Moonwort). 圈 About 1 foot high, divided into two segments above the middle, one of which is erect, bearing the fruit, the other spreading, triangular, membranous and much divided. Plant 8 inches apart.

ternatum $\diamond 6$ to 12 inches high. Fronds evergreen, resembling the preceding, but smaller and less divided. Plant 6 inches apart, with the new bud about an inch below the surface.

CAMPTOSORUS rhizophyllus (Walking-leaf). 圈 A little, low-creeping Fern, with evergreen fronds 4 to 9 inches long growing in tufts. Interesting and quite easy to grow in the rock-garden. If to be grown in the Fern-bed, use a good sprinkling of leaf-mold, raising the bed 2 to 3 inches, and plant on front edge about 6 inches apart. Do not cover the leaves. 30 cts. each, $\$ 2$ for $10, \$ 15$ per 100 .

CYSTOPTERIS bulbifera (Bladder Fern). * Light green fronds, which attain a length of nearly 3 feet, make it useful for massing on moist banks or for lining walks where a low carpet effect is desired. Plant the crowns just at the surface and 8 inches apart.

fragilis. 圈 Smaller than the preceding, growing but 4 to 8 inches high, with fronds two or three times divided. Forms nice clumps in shady, well-drained soil; plant 6 inches apart in beds.

DICKSONIA punctilobula (Hayscented, or Gossamer Fern). $\diamond$ One of the varieties that will grow in either sun or shade. It propagates itself by underground root-stalks and if planted in rich, porous soil will soon form masses. Sods for immediate effects, 60 cts. per sq. ft., $\$ 5$ for 10 sq. ft., $\$ 35$ per 100 sq. ft.

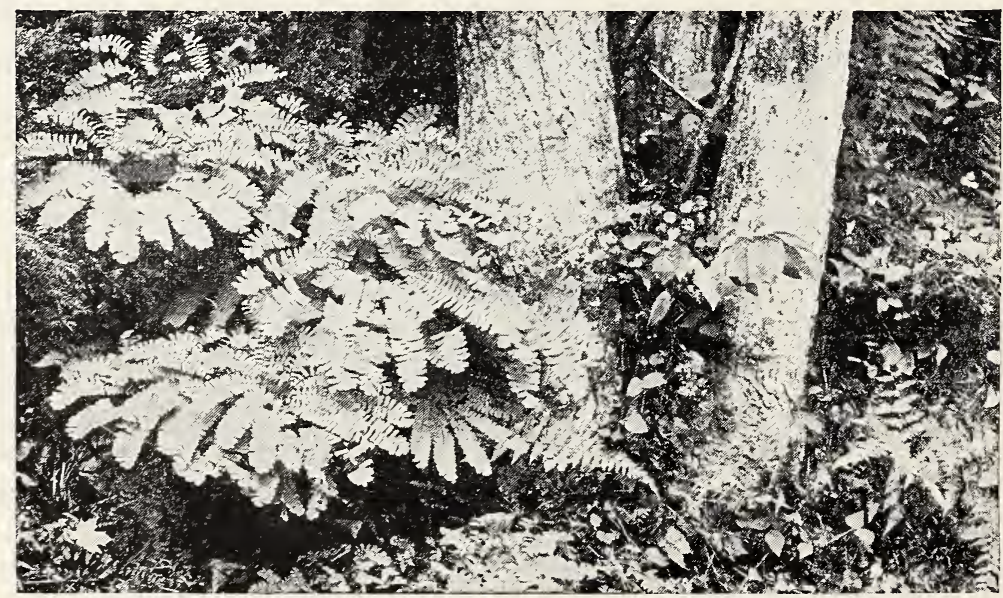

Maidenhair Fern (Adiantum pedatum) thrives in shaded locations. See page 2 


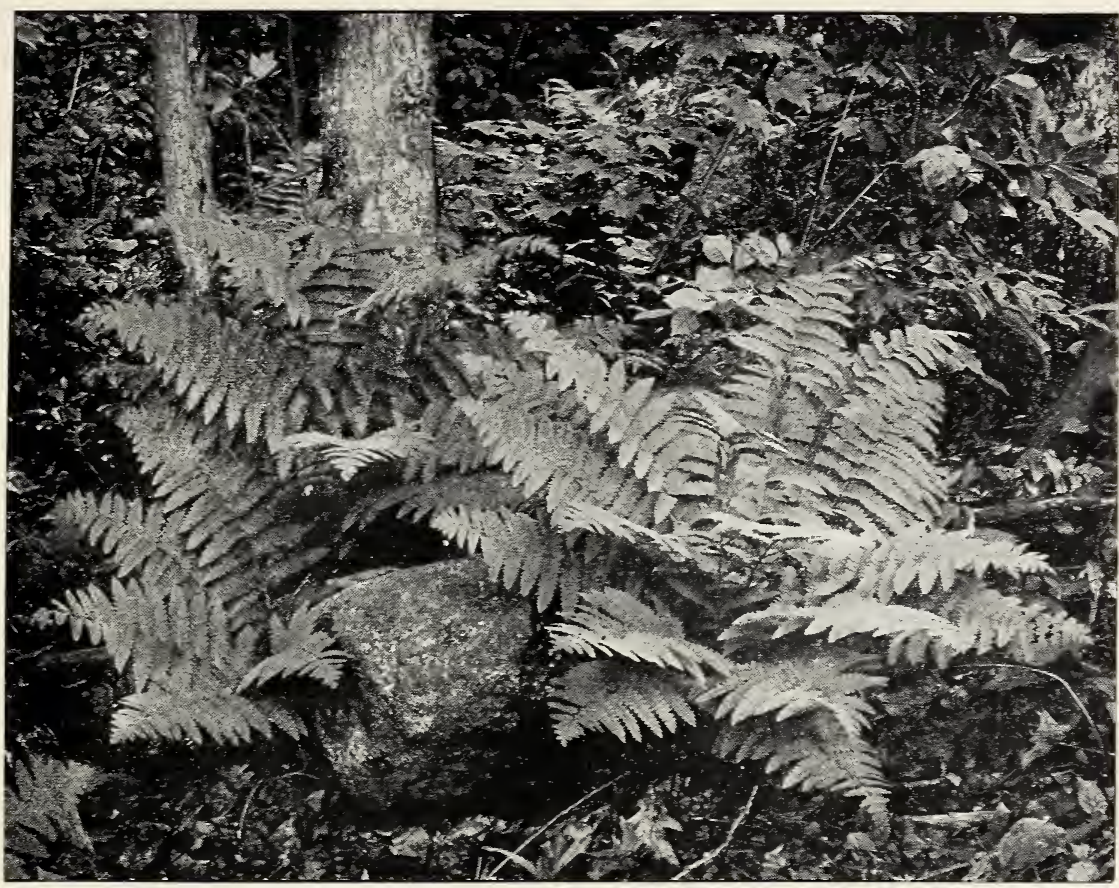

Osmunda Claytoniana grows from 2 to 3 feet high, is successful for shade and can be grown very well indeed in window boxes

ONOCLEA sensibilis (Sensitive Fern). $\diamond$ Grows in quite wet places, or will thrive in moist soils in sunny locations or shaded spots reaching a height of 1 foot. Plant 1 foot apart.

Struthiopteris (Ostrich Fern). Long, graceful, erect fronds make a most effective background for smaller Ferns, reaching a height of 1 foot, and the sterile ones 2 to 4 feet, with a width of 6 to 10 inches. Thrives in the open sun or shaded nook. Feed heavily with manure. 25 cts. each, \$2 for 10, \$15 per 100.

OPHIOGLOSSUM vulgatum (Adder's-Tongue Fern). A single leaf springs from the fibrous roots, bearing at the top a singular spike of fruit or spores. It is usually found in wet, open places, in low, grassy meadows. 15 cts. each, $\$ 1$ for 10 .

OSMUNDA regalis (Flowering Fern). ¥ Pale green fronds. One of the prettiest Iarge Ferns. Can be grown in still water, 2 or 3 inches deep, setting the crowns just above the water; also in moist soils, sun or shade. 2 to 3 feet high. Plant 2 or 3 feet apart. Large roots, 25 cts. each, \$2 for $10, \$ 15$ per 100.

Claytoniana. $*$ Clothed with loose wool when unfolding its fronds in spring, but soon becoming perfectly smooth. This Fern, 2 to 3 feet high, is found in rather dry, shaded places, and does quite weIl under cultivation and in boxes. Plant about 2 feet apart if several are needed. 25 cts. each, $\$ 2$ for $10, \$ 15$ per 100; extra-heavy, 50 cts. each, $\$ 4$ for 10 .

cinnamomea (Cinnamon Fern). * Larger than the preceding-often 5 feet high and 8 inches wide. Thrives in quite wet soil, in open sun or moist, shady places; usually found in mucky soil. 25c. ea., \$2 for 10, \$15 per 100; extra-heavy, 50c. ea., \$4 for 10.

PELLÆA atropurpurea (Purple Cliffbrake). This little Fern will convert a dry limestone wall into a veritable garden, as the roots cling to crevices in the stone. Fronds 4 to 12 inches Iong, 2 to 4 inches wide. S1 each.

PHEGOPTERIS Dryopteris (Beech Fern). * Has triangular fronds 3 to 5 inches wide, once or twice divided. Reaches a height of 1 foot in moist, rich, shaded places. It is benefited by adding a little leaf-mold to the soil. Plant 8 inches apart. 


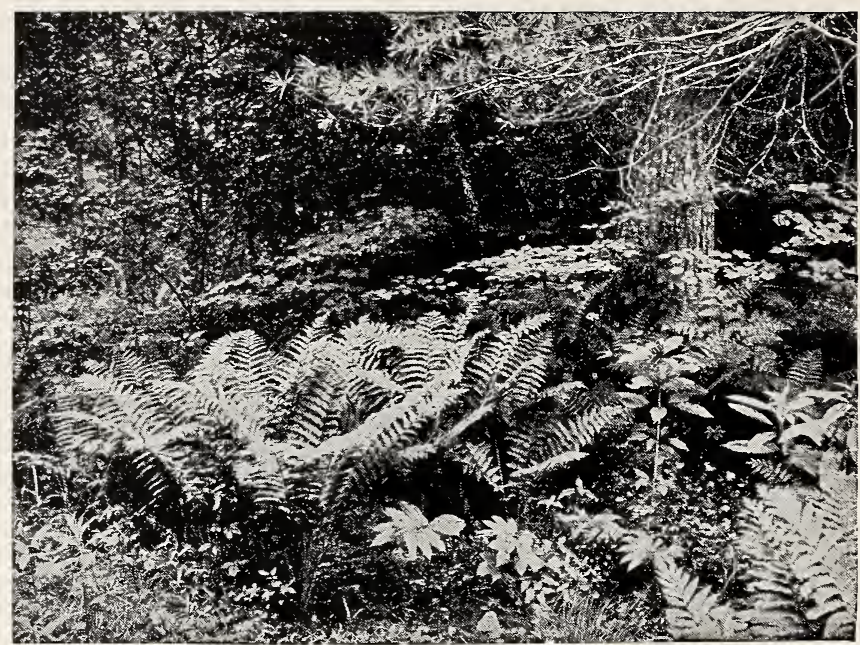

Osmunda cinnamomea (Cinnamon Fern). See page 5

Phegopteris hexagonoptera. 圈 A good Fern for the shady corner. It reaches a height of one foot, with fronds averaging from 7 to 12 inches in width-often broader than long. Plant 8 inches apart.

polypodioides. : $:$ Fronds smaller and darker green than the preceding, 8 inches high, often found on mossy banks just above the water of a mountain brook. A good Fern for the front border of a Fern-bed, and, if planted 6 inches apart, should in two years, make a solid clump.

POLYPODIUM vulgare (Common Polypody). $⿴ 囗$ One of the best evergreen species for rock-work. Grows 4 to 10 inches high, forming dense mats. Plant about 4 to 6 inches apart for quick results and cover the new buds slightly.

PTERIS aquilina (Common Brake). Commonly found throughout New England in light, sandy soil, and often in thin woodlands; will grow in either sun or shade.

WOODSIA ilvensis (Rusty Woodsia). $\otimes$ This Fern thrives in moist soils in shade, but needs good drainage; it grows about 6 inches high. Plant about 8 inches apart.

obtusa (Obtuse-leaved Woodsia). 圈 An easy Fern to grow, and quite desirable for rock-work. It will thrive in almost any shaded place not too wet. 6 to 12 inches high. Plant 8 inches apart in front of larger Ferns. It is benefited by the addition of a little leaf-mold.

WOODWARDIA angustifolia (Chain Fern). $\diamond$ Thrives in moist garden soil, even in highest rock gardens. 12 inches high by 3 to 4 inches wide. 25 cts. each, $\$ 2$ for 10 .

virginica. $\diamond$ Is larger than the preceding -2 feet high by 3 to 5 inches broad. Can be grown in any garden soil. Plant 12 to 14 inches apart if a permanent bed is desired.

\section{CLUB MOSSES}

LYCOPODIUM clavatum (Club Moss). $*$ This variety runs extensively, sometimes 6 feet or more. Stems round, and covered with small, light green, pointed leaves. complanatum. * The short stems, 3 to 6 inches high, have flat-topped, leafy branches. The brown, running stems are often 8 feet long.

dendroideum (Ground Pine). * Used for Christmas greens. Grows about 6 inches high, in moist, shady places; evergreen, quite showy, and does weIl under cultivation. lucidulum (Shining Club Moss). 因 Evergreen, 3 to 8 inches high; leaves $1 / 2$ inch long, growing thickly along the stalk. Plant in moist shady places, 3 to 4 inches apart.

SELAGINELLA rupestris. $\diamond$ A little, low, grayish green moss-like plant, 1 to 3 inches high, growing in little tufts on exposed rocks.

apus. $\Leftrightarrow$ A pretty little creeper, with fine, scale-like leaves. Makes a fine ground work for small flowering plants. Grows in open sun or in wet or moist places. 


\section{COLLECTIONS OF HARDY FERNS BOUND TO PLEASE LOVERS OF WILD GARDENS}

The following collections are made up to help in selecting for special needs, and should be sent by express or freight

If to be planted in beds, the height given after each kind will indicate where it should go. If in beds where they are to be seen from all sides, the tall kinds in the center; but if in an angle of the house or wall, plant the taller kinds the farthest back, 8 inches or a foot from the wall, and the smaller kinds in front.

\section{No. 1, \$5. For Open Sun Culture}

This collection is desirable for the open border, and all the Ferns, being rather tall, can be grown as single specimens or for massing, with or without flowers.

5 Onoclea Struthiopteris, 2 to 4 feet.

5 Osmunda Claytoniana, 2 to 3 feet.
20 Dicksonia punctilobula, 1 to 2 feet.

5 Asplenium Filix-fœmina, 2 to 3 feet.

\section{No. 2, \$5. For Dry, Shady Places}

These Ferns will grow in a dry, shady place. PIant them where flowers, as a rule, do not thrive.

10 Aspidium acrostichoides, 1 foot.

10 Aspidium marginale, 1 to 2 feet.
10 Dicksonia punctilobula, 1 to 2 feet.

5 Osmunda Claytoniana, 2 to 3 feet.

\section{No. 3, \$6. For Moist, Shady Places}

This collection is fine and easily handled in moist, shady places; also for Iarge rockery.

5 Adiantum pedatum, 1 foot.

5 Aspidium cristatum, 1 foot.

5 Aspidium acrostichoides, 1 foot.

5 Aspidium spinulosum, 1 to $1 \frac{1}{2}$ feet.

5 Aspidium marginale, 1 to 2 feet.
5 Asplenium thelypteroides, 2 to 3 feet.

5 Asplenium Filix-fœmina, 2 to 3 feet.

5 Phegopteris hexagonoptera, 1 foot.

5 Woodwardia virginica, 2 feet.

\section{No. 4, \$5. For Wet, Open Ground}

These Ferns are very useful for border of a lake or low, wet ground.

10 Aspidium Thelypteris, 1 foot.

10 Onoclea sensibilis, 1 foot.
10 Osmunda regalis, 2 to 3 feet.

10 Woodwardia virginica, 2 feet.

\section{No. 5, \$6. Low Evergreen Ferns for Rockery in Shade}

This is a beautiful collection of low-growing Ferns and easily managed.

10 Asplenium ebeneum, 6 to 15 inches. 10 Polypodium vulgare, 4 to 10 inches.

10 Asplenium Trichomanes, 3 to 6 inches. 5 Woodsia obtusa, 6 to 12 inches.

10 Camptosorus rhizophyllus, 4 to 9 inches.

\section{No. 6, \$5. Low Evergreen Ferns for Dry, Rocky Ledge}

10 Asplenium Trichomanes, 3 to 6 inches. 10 Polypodium vulgare, 4 to 10 inches.

10 Woodsia obtusa, 6 to 12 inches. 10 Woodsia ilvensis, 6 inches.

All of the Ferns listed in this catalogue can be shipped at any time during the growing season by simply cutting back the fronds. This checks the growth temporarily, but soon after the planting new foliage forms and in a short time the plants will be as beautiful as ever. 


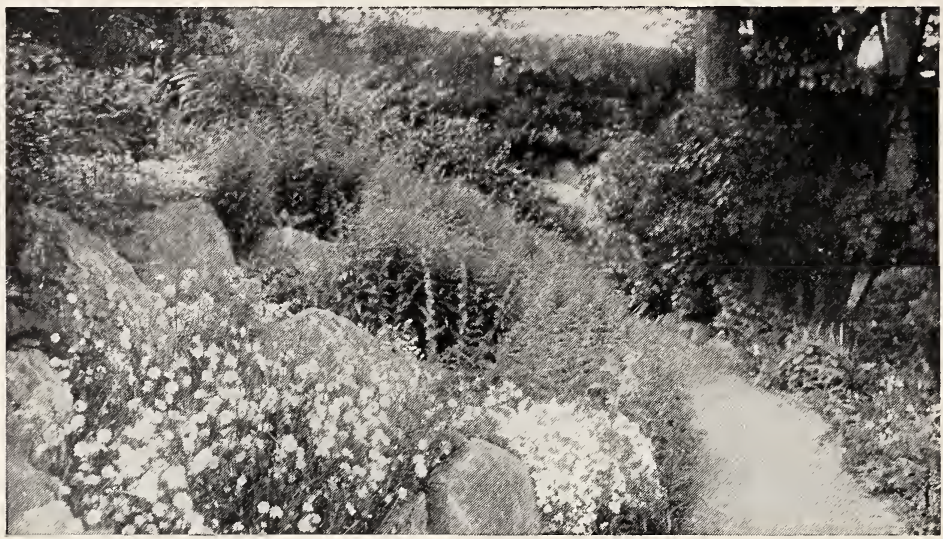

\section{THE HARDY ROCK-GARDEN}

Early spring flowers make a better and more natural display in a rock-garden than in the ordinary flower-bed. The construction of a rock-garden is very simple. Select a shaded location, where the ground has ordinary moisture. Begin at the bottom and build up (do not throw together a heap of stones and then cover with earth); each boulder should be placed so as to allow moisture from rains to run into the garden, not away from it. After placing a boulder, fill around it with earth, being sure that there are no spaces unfilled, as air-spaces will prevent moisture from coming up from below. The top of a rock-garden must have direct contact with the ground by way of firm earth in order to allow the moisture to work up among the stones and give the proper conditions for growing rock plants. It is not necessary to build a rock-garden more than 8 to 10 inches above the surrounding level.

The soil in which the plants are directly placed should be rich woods' earth. The main body of the rock-garden can be ordinary garden soil, yet to obtain the best results the top soil should be rich woods' dirt. Many native plants do not thrive in garden soil.

It is impossible to give explicit directions for making a rock-garden, such as will cover all needs, yet I will be very glad to advise anyone who may contemplate the building of such a garden, giving specific directions as may be necessary. If desired, I will send a competent representative to plan a rock-garden; terms given on application.

\section{ROCK-GARDEN PLANTS FOR A MOIST, SHADY PLACE}

\section{FERNS (For description, see Ferns)}

Adiantum pedatum, 12 to 15 inches. Aspidium aculeatum Braunii, 12 to 15 in. Aspidium cristatum, 12 inches. Aspidium Filix-mas, 1 to 2 feet. Aspidium marginale, 1 to 2 feet. Aspidium munitum, 12 to 15 inches. Aspidium spinulosum, 1 to $11 / 2$ feet. Asplenium ebeneum, 6 to 12 inches. Asplenium Trichomanes, 3 to 6 inches. Camptosorus rhizophyllus. (Prostrate.) Cystopteris bulbifera, 6 to 12 inches. Cystopteris fragilis, 6 to 8 inches. Osmunda Claytoniana, 2 to $3 \mathrm{ft}$. Osmunda regalis, $1 \frac{1}{2}$ to 3 feet. Pellæa atropurpurea, 2 to 4 inches. Phegopteris Dryopteris, 6 to 10 inches. Phegopteris hexagonoptera, 8 to 12 inches. Phegopteris polypodioides, 8 to 12 inches. Polypodium vulgare, 4 to 10 inches.

Woodsia ilvensis, 4 to 8 inches.

Woodsia obtusa, 6 to 12 inches.

\section{FLOWERING PLANTS}

(See Herbaceous Plants for descriptions)

Actæa alba, 1 to 2 feet.

Anemone pennsylvanica, 1 foot.

Aquilegia canadensis, 8 to 12 inches.

Arisæma triaphyllum, 1 to $11 / 2$ feet.

Asarum canadense, 4 to 6 inches.

Asarum virginicum, 4 to 6 inches.

Aster cordifolius, $11 / 2$ to 2 feet.

Aster corymbosus, 18 to 30 inches.

Aster undulatus, 18 to 30 inches.

Baptisia tinctoria, 1 to 2 feet.

Caulophyllum thalictroides, 1 to $1 \frac{1}{2}$ feet.

Chimaphila maculata, 3 to 6 inches.

Cimicifuga racemosa, 2 to 4 feet.

Claytonia virginica, 3 to 5 inches.

Dentaria diphylla, 4 to 8 inches.

Dicentra Cucullaria, 4 to 8 inches.

Erythronium albidum, 6 inches.

Erythronium americanum, 6 inches.

Erythronium grandiflorum, 6 inches.

Erythronium Hendersoni, 6 inches. 


\section{ROCK-GARDEN PLANTS FOR A MOIST, SHADY PLACE, continued}

Erythronium revolutum, 6 inches.

Eupatorium ageratoides, $1 \frac{1}{2}$ to 3 feet.

Galax aphylla, 6 to 8 inches.

Gentiana Andrewsii, 1 to 2 feet.

Geranium Robertianum, 6 to 12 inches.

Hepatica acutiloba, 4 to 6 inches.

Hepatica triloba, 4 to 6 inches.

Heuchera americana, 8 to 12 inches.

Houstonia cærulea, 2 to 3 inches.

Iris cristata, 4 to 8 inches.

Iris verna, 4 to 8 inches.

Lilium philadelphicum, 1 to 2 feet.

Lobelia cardinalis, $11 / 2$ to 3 feet.

Lobelia syphilitica, 18 to 30 inches.

Mertensia virginica, 1 to $1 \frac{1}{2}$ feet.

Mitchella repens. (Prostrate.)

Mitella diphylla, 4 to 8 inches.

Nepeta Glechoma. (Prostrate.)

Phlox amœna, 6 to 12 inches.

Phlox divaricata, 8 to 18 inches.

Phlox subulata, 3 to 5 inches.

Phlox subulata alba, 3 to 5 inches.

Podophyllum peltatum, 8 to 15 inches.

Polygonatum biflorum, 1 to 2 feet.

Sanguinaria canadensis, 6 to 12 inches.

Shortia galacifolia, 4 to 6 inches.
Smilacina bifolia, 3 to 4 inches.

Smilacina racemosa, 8 to 18 inches.

Solidago cæsia, 1 to $11 / 2$ feet.

Solidago nemoralis, 1 to $11 / 2$ feet.

Thalictrum anemonoides, 6 to 12 inches.

Thalictrum dioicum, 1 to 2 feet.

Tiarella cordifolia, 6 to 10 inches.

Trillium cernuum, 10 to 15 inches.

Trillium erectum, 10 to 15 inches.

Trillium erectum album, 10 to 15 inches.

Trillium erythrocarpum, 8 to 12 inches.

Trillium grandiflorum, 10 to 15 inches.

Trillium nivale, 4 to 6 inches.

Trillium recurvatum, 12 inches.

Trillium stylosum, 8 to 12 inches.

Uvularia perfoliata, 8 to 12 inches.

Uvularia sessilifolia, 8 to 12 inches.

Vinca minor. (Trailer.)

Viola canadensis, 4 to 12 inches.

Viola canina sylvestris, 4 to 8 inches.

Viola cucullata, 4 to 8 inches.

Viola palmata, 6 to 10 inches.

Viola pubescens, 8 to 12 inches.

Viola rotundifolia, 2 to 4 inches.

Viola septentrionalis, 4 to 8 inches.

\section{ROCK-GARDEN PLANTS FOR OPEN, SUNNY PLACES}

The following list of plants is suited to growing in a sunny rock-garden. For the most part this list is composed of the dwarf plants which are particularly desirable for this class of gardening. You will find them listed and described under the head of Hardy Perennials unless otherwise noted.

Alyssum saxatile.

Anemone pulsatilla.

Aquilegia canadensis.

Arabis mollis.

Arenaria cæspitosa.

Aster alpinus.

Aster alpinus albus.

Campanula carpatica.

Campanula carpatica alba.

Campanula rotundifolia.

Cerastium tomentosum.

Delphinium grandiflorum.

Dianthus deltoides.

Houstonia cærulea.

Iberis sempervirens.

Iris cristata.

Iris verna.

Leophyllum buxifolium prostratum. (See Evergreens.)

Lupinus perennis.

Mertensia virginica.

Mitchella repens.

Pachysandra terminalis.

Phlox amœna.
Phlox divaricata.

Phlox subulata.

Phlox subulata alba.

Primula acaulis.

Primula Polyantha.

Sanguinaria canadensis.

Saxifraga virginiensis.

Sedum acre.

Sedum album.

Sedum kamtschaticum.

Sedum lydium.

Sedum saramentosa.

Sedum sexangulare.

Sedum stoloniferum coccineum.

Sempervivum.

Thymus Serpyllum.

Thymus Serpyllum albus.

Thymus Serpyllum coccineus.

Vinca minor.

Viola cornuta.

Viola cornuta alba.

Viola lutea.

Viola odorata.

Viola septentrionalis.

If you have a shady nook in the garden, where you find it difficult to make ordinary plants grow, try shade-loving plants-the Erythroniums, Claytonia, the native Aquilegia, and some of the ferns. You will be surprised at the charming results. 


\section{HARDY PERENNIALS}

\section{FLOWERS THAT LIVE YEAR AFTER YEAR}

The word Native will possibly assist customers in selecting plants for a garden where only natives are required. There is no class of plants which gives the same permanency of effect as do these. When established they bloom year after year while many of the so-called hardy plants pass their period of usefulness after two or three years.

Prices on Perennials, 25 cts. each, $\$ 1.50$ for $10, \$ 12$ per 100 , unless otherwise noted

\section{ACT EA}

alba (White Baneberry). 圈 Native. Racemes of white flowers, followed by white fruit. Fine for rock-work or the shady corner. Provide it with a friable loam rich in humus. 35 cts. each, $\$ 2.50$ for $10, \$ 20$ per 100 .

rubra (Red Baneberry). Native. Same as preceding but with red fruit. 35 cts. each, $\$ 2.50$ for $10, \$ 20$ per 100 .

\section{ALETRIS}

farinosa (Colic-root). Native. This plant grows where the soil is rather dry. It bears small white flowers on a slender stalk; appear as if sprinkled with meal. 1 to $1 \frac{1}{2}$ feet high.

\section{ANEMONE}

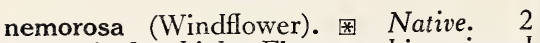
to 4 inches high. Flowers white, tinged with purple; partial shade. 15 cts. each, $\$ 1$ for $10, \$ 8$ per 100 .

canadensis (pennsylvanica). 12 to 18 inches high. Large, single, pure white flowers. Plant in the moist border in a sunny place. Quite hardy. 20 cts. each, $\$ 1.25$ for $10, \$ 10$ per 100 .

pulsatilla. $\diamond$ The Pasque Flower of Europe. Flower single, blue or reddish purple, about 2 inches across. Thrives best in welldrained soil. 30 cts. each, $\$ 2.50$ for 10 .

\section{ANTENNARIA}

margaritacea (Pearly Everlasting). * Native. About a foot high; white woolly leaves and pearly white flowers in broad heads. Can be kept a long time if cut before maturing and dried; quite fragrant. Prefers full sun or partially shaded situations and dry soil. 15 cts. each, $\$ 1$ for $10, \$ 8$ per 100 .

No plants excel Perennials for real values in home gardens.

\section{AQUILEGIA}

alpina (Columbine). From Switzerland. Flowers blue, large, and quite showy. May and June. 1 foot. $30 \mathrm{cts}$. each, $\$ 2$ for 10 .

canadensis. Native. Yellow and red flowers an inch long. Very desirable for rockeries. 8 to 20 inches high.

vulgaris. From Europe. Flowers are violet.

\section{ARABIS}

Kelleri. A new variety of Rock Cress, growing from 3 to 4 inches high. The flowers are pure white and somewhat larger than the older varieties. $30 \mathrm{cts}$. each, $\$ 2.50$ for 10 .

mollis. Early in spring it bears masses of pure white flowers. It forms good clumps, carpeting the soil with small shining leaves.

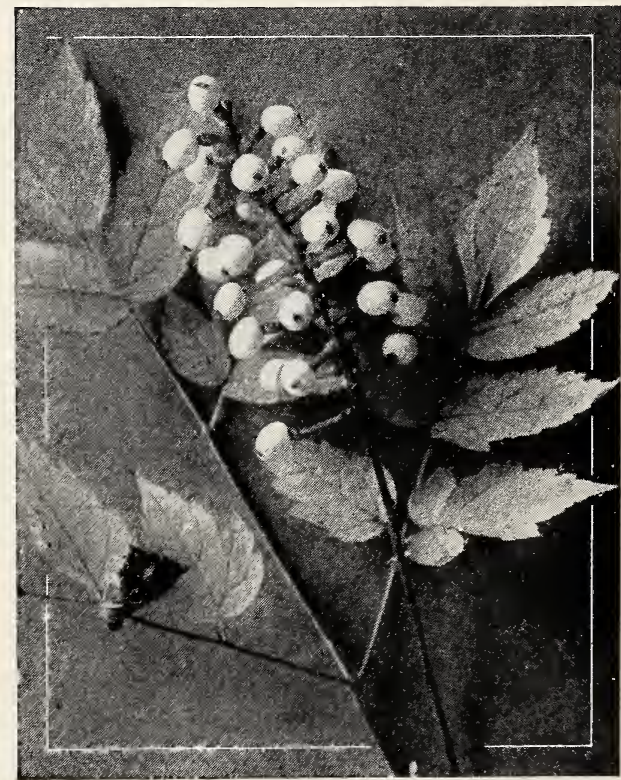

Actæa alba in fruit 


\section{ARENARIA}

cæspitosa. Known in some sections as "Spergula." The plants form tufts of bright green leaves and soon cover the ground like a carpet. It is desirable for rock-gardens, for crevices in flag walks, or for cemetery coverings. The small flowers are pure white.

\section{ARISEMA}

triphyllum (Wild Turnip; Jack-in-thePulpit). Let this woodland gem preach for you.

\section{ASARUM}

canadense (Wild Ginger; Canada Snakeroot). \# Native. Kidney-shaped leaves 3 to 5 inches wide and a single purplish flower close to the ground. Plant in the shady corner with your ferns. 15 cts. each, \$1 for 10, \$8 per 100.

\section{ASCLEPIAS}

tuberosa (Butterfly Weed). Native. A foot high with large heads of orange flowers. Thrives on dry sandy banks. 25 cts. each, \$2 for 10, \$15 per 100.

\section{ASTER}

These are easily grown and deserve more attention from lovers of wild flowers. Those named are among the most showy of the genus.

alpina (Rock Aster). For the rock-garden or the front of the hardy border, this little plant will give much pleasure. It grows 3 to 10 inches high, bearing Iarge showy purple flowers in May and June. 25 cts. each, \$2 for 10.

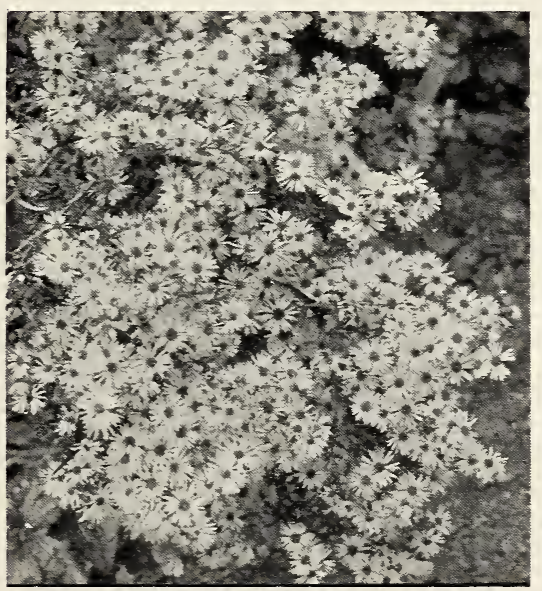

Aster novi-belgii

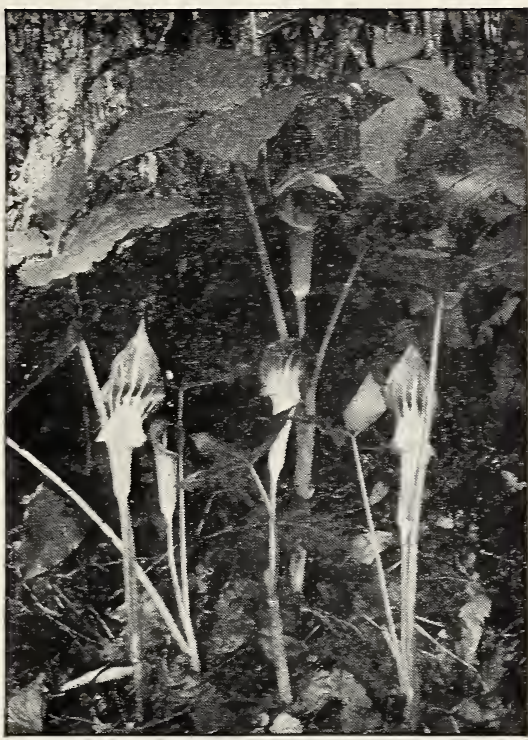

Arisæma triphyllum

ASTER, continued

alpina alba (Snowflake). White flowers with yellow centers. A fine rock-garden sort for sunny situations. 8 inches high. 25 cts. each, \$2 for 10.

cordifolius. Native. Pale blue flowers in autumn. Quite showy. Prefers shaded situations. 1 to 2 feet.

corymbosus. Native. White flowers. A prominent Aster of our dry New England woods in late autumn. 1 to 2 feet. ericoides. $\rightarrow$ Native. GracefuI, wandlike, spreading branches are covered with fine green or purple leaves, and dotted with large, white flowers. Plant in dry, sandy soil.

lævis. $*$ Native. A beautiful species with sky-blue flowers. Grows in dry woodland.

linariifolius (Double-bristled Aster). $\neq$ Native. Grows 8 to 12 inches high; short, linear leaves and Iarge, showy, violet flowers in Iate autumn. Plant in dry, open places or woods.

multiflorus. (s) Native. Branches covered with small, white flowers. Fine for dry, open places. 1 to 2 feet high. 15 cts. each, \$1 for 10, \$8 per 100.

novæ-angliæ. $\Leftrightarrow$ Native. Stout stalks, 3 to 8 feet high. Flowers violet and purple. Moist ground.

novi-belgii. $\diamond$ Native. Plants 2 to 3 feet high, with Iarge, pale blue flowers. A wet, open bank is best suited for its growth. 
ASTER, continued

undulatus. Native. One of the most showy of our wild Asters, growing about 2 feet high, with bright blue flowers; delights in dry, shady place; flowers in Iate autumn.

Asters in varieties for shady places, $\$ 10$ per 100. Asters in varieties for open sunny places, \$10 per 100.

\section{BAPTISIA}

tinctoria (Wild Indigo). Native. Flowers yellow. Forms good clumps in the open border. 1 to 2 feet high.

\section{CAMPANULA}

carpatica. \& Large, blue flowers in summer. Sunny border or rockery. 25 cts. each, \$2 for 10 .

carpatica alba. Flowers white. 25 cts. each, \$2 for 10 .

rotundifolia (Blue Bells of Scotland). In shady places the plants often grow 2 feet high. The flower-buds are upright, opening into a nodding, bellshaped blue flower. Blooms freely, and is happy in any moist soil. $25 \mathrm{cts}$. each, $\$ 2$ for $10, \$ 15$ per 100 .

\section{CAULOPHYLLUM}

thalictroides (Blue Cohosh). 圈 Native. A thrifty plant of our New England hillsides. Flowers greenish yellow, followed by the large blue berries.

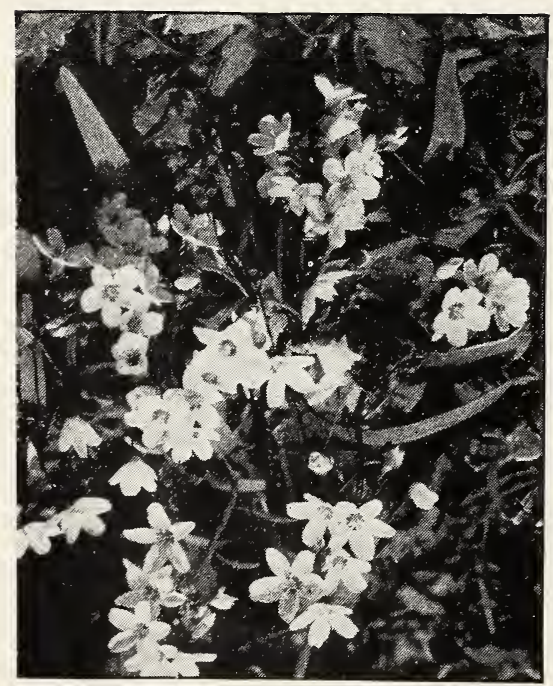

Claytonia virginica

\section{CENTAUREA}

montana (Mountain-bluet). Very Iarge deep purple blossoms borne from July to September; valuable for cut-flowers. 2 feet.

\section{CERASTIUM}

tomentosum. Leaves silvery white; masses of pure white flowers in early summer; used for edging and mixed borders. 4 to 6 inches high.

\section{CHELONE}

glabra (Snake Head). $\diamond$ Native. Flowers white to rose-color, in late autumn; grows in wet places. 1 to 2 feet high.

\section{CHIMAPHILA}

maculata. 圈 Native. Low-growing plants with spotted leaves and rather showy white or pink flowers. Plant it with the partridge berry.

umbellata (Prince's Pine). Native. An evergreen 6 to 10 inches high with bright shiny leaves; flowers flesh color in June.

\section{CIMICIFUGA}

racemosa (Black Snakeroot). 因 $\diamond \mathrm{Na}$ tive. Tall plants with white flowers in elongated racemes. Desirable for a moist, shady corner. 4 to 6 feet high.

\section{CLAYTONIA}

virginica (Spring Beauty). 圈 Native. Has large, rose-colored flowers in early spring. Plant in shady place. 15 cts. each, $\$ 1$ for $10, \$ 8$ per 100 .

\section{CLINTONIA}

borealis. 圈 Native. Flower-stalks are about 6 inches high, bearing at the top a few rather large, greenish yellow, lilylike flowers in early spring. Flant in a cool, shady place. 15 cts. each, $\$ 1$ for 10 , $\$ 8$ per 100 .

\section{CONVALLARIA}

majalis (Lily-of-the-Valley). Native. Flowers white. The plants I offer have three to five pips each.

\section{CORNUS}

canadensis (Dwarf CorneI). 关 Native Plant 6 inches high, with four broad leaves at the top. Flowers greenish, surrounded by a showy white involucre, followed by bright red berries. Desirable for a shady corner; fine for massing. 30 cts. each, $\$ 2.50$ for 10 , $\$ 20$ per 100 .

Prices on Perennials, 25 cts. each, $\$ 1.50$ for $10, \$ 12$ per 100 , unless otherwise noted 


\section{COPTIS}

trifolia (Gold-Thread). 因 Native. A little, Iow evergreen, with bright shiny leaves and white flowers. Plant in a moist shady place.

\section{DELPHINIUM}

grandiflorum. Low-growing plants with finely cut leaves. The Iarge and graceful flowers appear aII summer in an almost endless variety of blue, from nearly pure white to finest tints of dark blue. Should be planted in a sunny spot, where they can have good drainage.

\section{DENTARIA}

diphylla (Toothwort; Pepper-Root). * Native. Plants grow 6 to 15 inches high, with a single corymb of pretty white flowers in May. Rich, shady places. 15 cts. each, \$1 for $10, \$ 8$ per 100.

\section{DIANTHUS}

barbatus (Sweet William). Showy flower-heads $2 \frac{1}{2}$ to 3 inches broad, of brilliant colors-pure white, pink, scarlet, and very dark crimson. Fine for clumps in beds and borders. $1 \frac{1}{2} \mathrm{ft}$.

deltoides (Maiden Pink). A dwarf creeping sort, bearing small, deep red flowers with crimson centers; used for borders and covering the soil with tufts of green.

plumarius, Cyclops (Garden Pink). Colors range from white to deep pink. Fine border plant.

\section{DICENTRA}

Cucullaria (Dutchman's Breeches). $\odot$ Native. A very early spring flower, with delicate divided Ieaves; grows about 8 inches high. Greenish white flowers, tinged with rose. 15 cts. each, \$1 for 10, \$8 per 100.

canadensis (Squirrel Corn). Native. Similar to above in flower, Ieaf, and manner of growth. 15 cts. each, $\$ 1$ for $10, \$ 8$ per 100 .

\section{DIGITALIS}

purpurea gloxiniæflora (Foxglove). $\diamond$ Large, showy flowers in June or July. The thimble-shaped blooms are mottled and striped with blue and purple, with scarlet and crimson, and are extremely striking in the flower-border. A good border plant in front of shrubbery, reaching a height of 2 feet. Mixed colors.

\section{DIPLOPAPPUS}

linariifolius. See Aster.

\section{DODECATHEON}

Meadia (Shooting Star). 圈 Native. A very pretty, smooth perennial, with rose-colored or sometimes white flowers in May or June. This is sometimes called "American Cyclamen." It thrives in rich, moist woods, or in the open border. 30 cts. each, $\$ 2.50$ for $10, \$ 20$ per 100.

\section{ERYTHRONIUM}

americanum albidum. Native. An extremely interesting spring flower with white, dog-toothed-violet flowers and light green leaves. Succeeds in any light soil in partially shaded place. 15 cts. each, $\$ 1$ for $10, \$ 8$ per 100 .

grandiflorum. Native. 1 to 5-flowered, slender stemmed stalks with very bright yellow blooms. Rich, well-drained soil in shaded place. 15 cts. each, $\$ 1$ for 10 , $\$ 8$ per 100 .

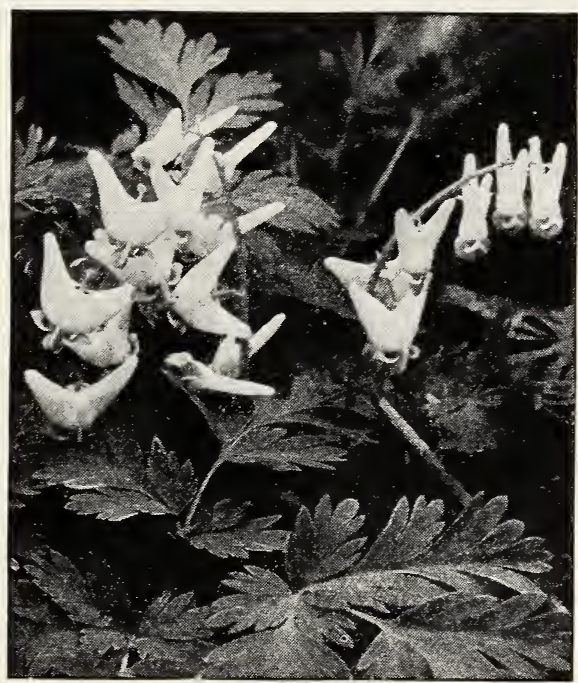

Dicentra Cucullaria

Hendersoni. Native. The flowers are light purple, with an extremely dark red center which in some specimens appears almost black. 15 cts. each, \$1 for $10, \$ 8$ per 100 .

Revolutum. Native. The flower-stems are from 14 to 18 inches high and often carry four blooms which open white but change to light lilac or purple. 15 cts. each, \$1 for $10, \$ 8$ per 100 . 


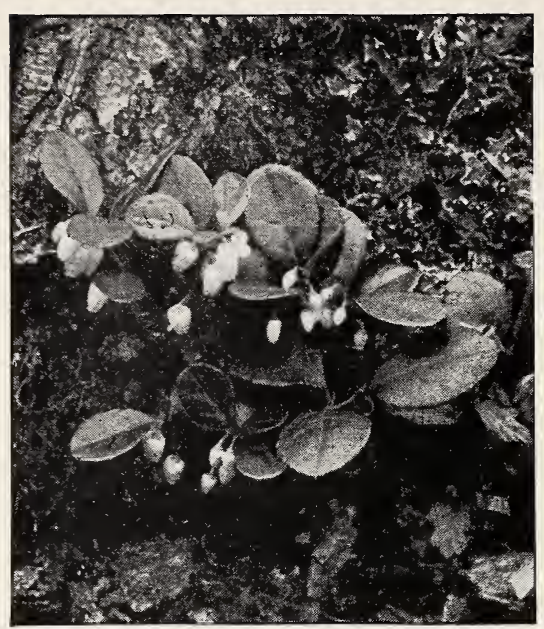

Gaultheria procumbens

\section{ERYSIMUM}

pulchellum. A fine little rock plant; with yellow flowers in spring; forms little clumps.

\section{EUPATORIUM}

ageratoides (White Snakeroot). $\diamond \mathrm{Na}$ tive. Grows 2 to 3 feet high, with a profusion of smaII, white flowers, in heads in Iate summer. Very desirable for planting in woodlands.

perfoliatum (Thoroughwort). $\diamond$ Native. Reaches a height of 2 to 3 feet with opposite leaves and flat heads of white flowers; moist places.

purpureum (Trumpet Weed; Joe Pye Weed). $\diamond$ Native. Plants 4 to 10 feet high, with smooth, purple stalks, leaves in whorls, and large, showy, purple heads of flowers, borne on top. Found in wet meadows and along streams.

\section{FUNKIA}

Thomas Hogg. Foliage banded with clear white. A very choice variety, with large, purplish lilac flowers.

\section{GALAX}

aphylla. 圈 Native. A pretty little evergreen from the mountains of North Carolina, having shining red or green leaves. Stalks a foot high, bearing many small, white flowers. Hardy in cold latitudes. 30 cts. each, $\$ 2$ for 10 , $\$ 15$ per 100.

\section{GAULTHERIA}

procumbens (Aromatic Wintergreen). * Native. A low evergreen, with bright green leaves. Flowers white followed by the bright red berries, which remain until the next season. Give the bed a covering of leaves. It takes a whole season to establish this plant. Clumps, 30 cts. each, $\$ 2.50$ for $10, \$ 20$ per 100 .

\section{GENTIANA}

Andrewsii (Closed Gentian). 图 Native. A pretty and strong-growing northern species, with clusters of blue flowers an inch or more in length. Plant in rich, moist soil. At home along the banks of a brook in shady places. One of our most interesting native plants.

\section{GERANIUM}

maculatum (Wild Crane's Bill). $@ N a$ tive. The Wild Geranium of our woods and fields. Flowers rather large, light purple, are borne from April to August. 20 cts. each, $\$ 1.25$ for 10 , $\$ 9$ per 100 .

Robertianum (Herb Robert). 図 Native. This little biennial is pretty for rockeries. It begins blooming in June and continues until October. Leaves strongscented; flowers small, red-purple. Thrives best in fairly moist soil. 15 cts. each, $\$ 1$ for 10 .

\section{HEPATICA}

acutiloba (Acute-lobed Hepatica). 圈 Native. An early blooming western plant with white, pink, or purple flowers in early spring.

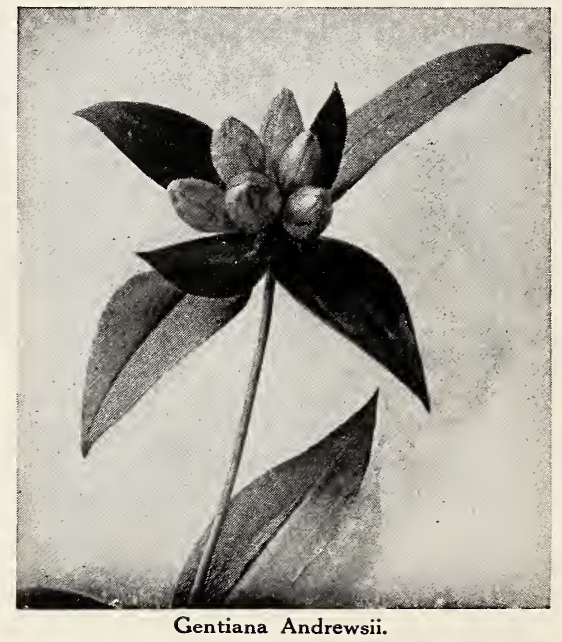




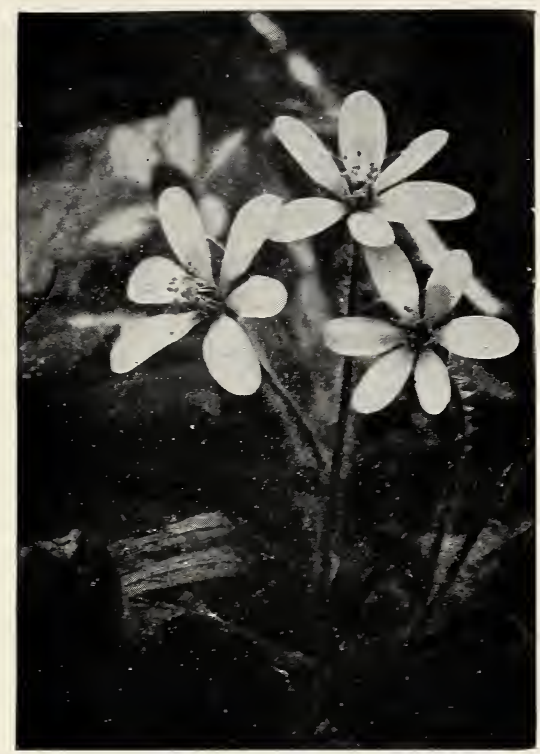

Hepatica triloba

\section{HEPATICA, continued}

triloba (Round-Iobed Hepatica). \& $\mathrm{Na}$ tive. One of the earliest of our wild wood flowers. Leaves three-lobed; the flowers are pink and dark purple. Fine for massing in the shady corner or open woods.

\section{HEUCHERA}

americana. Native. Beautifully marbled evergreen leaves. Flowers not showy. The beauty of this plant is in the foliage. 30 cts. each, \$2 for 10.

\section{HIBISCUS}

Moscheutos rosea (Pink Rosemallow). Thrives in any soil, particularly in moist places, growing 3 to 5 feet tall, with a wealth of dark green foliage and a profusion of 6-inch rosy red flowers with darker centers. July to September. Nothing finer for massing in meadows.

\section{HOUSTONIA}

cærulea (Bluets). Native. A little low biennial, 2 to 4 inches high, sparingly branched from the base. Flowers small, delicate light blue, sometimes pale lilac or white, with a yellowish eye. Grows in tufts in open, moist, or grassy places. Blooms in May. 15 cts. each, $\mathrm{S} 1$ for 10 , \$8 per 100.

\section{HYPOXIS}

erecta (Star Grass). Native. A little wood plant, with grass-like leaves and rather Iarge yellow flowers.

\section{IBERIS}

sempervirens (Candytuft). From Canada. Quantities of pure white flowers. One of the choicest for cutting. Hardy. 30 cts. each, \$2.50 for 10.

\section{IRIS}

cristata (Crested Iris). Native. A little low species no more than 2 or 3 inches high, found wild in the southern states. Flowers light blue, marked with white. Fine for the open border.

hexagona. Flowers blue, appearing close to the ground the last of June. Height 18 inches. 25 cts. each, S2 for 10.

Pseudacorus. See Bog-Plants.

verna. Native. A little low Iris with blue flowers having yellow center.

versicolor. Native. About 20 inches high with pretty blue flowers. A mass of this variety in bloom is a sight which one will not soon forget. Use it freely in moist places. 20 cts. each, $\$ 1.25$ for 10 , $\$ 10$ per 100.

\section{LILIUM}

canadense (Wild Meadow Lily). $\Leftrightarrow \mathrm{Na}$ tive. Grows 2 to 4 feet high, with one to many yellow or yellowish red flowers. Plant in moist weIl enriched soil.

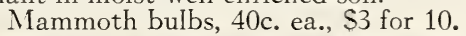

Flowering size, 25c. ea., \$1.50 for 10.

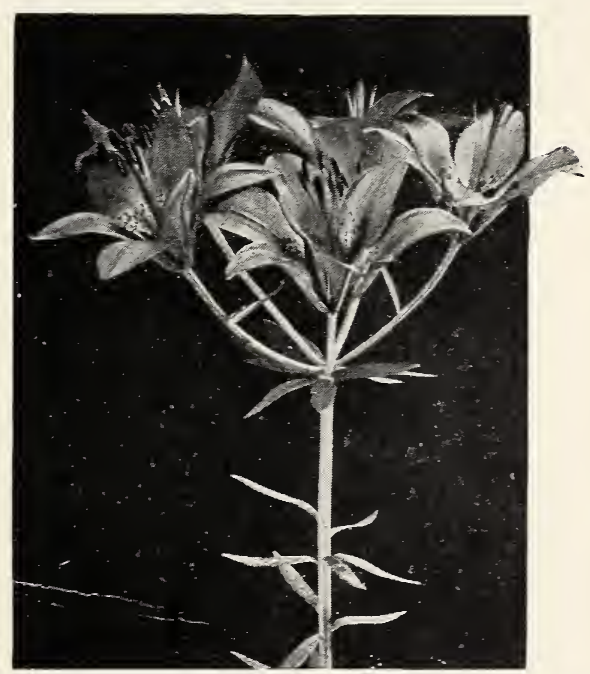

Lilium philadelphicum. See page 16 


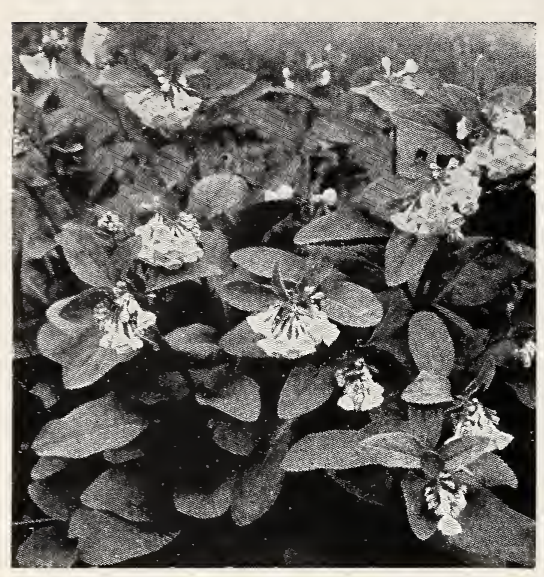

Mertensia virginica

LILIUM, continued

Grayi. Native. Flowers deep red. One of the finest for planting in shady places. 25 cts. each, $\$ 2$ for $10, \$ 15$ per 100 .

philadelphicum (Wild Orange-Red Lily). $\diamond$ Native. Reaches a height of 1 to 2 feet with one to two upright, open, bellshaped flowers, reddish orange, spotted with purple. Plant in a well-drained soil in sun or shade.

superbum (Superb Orange Lily). $\diamond N a$ tive. Large bulbs, 25 cts. each, $\$ 2$ for 10 , $\$ 15$ per 100 .

\section{LOBELIA}

cardinalis (Cardinal-flower). Native. One of the showiest of our wild flowers. It is 2 to 4 feet high, with large, deep red blossoms along the upper part of the stalk. Will thrive in any garden soil or along the border of a lily pond or brook in water 2 or 3 inches deep.

syphilitica (Great Blue Lobelia). $\diamond \mathrm{Na}$ tive. Similar in growth to the last, but the flowers are blue, streaked with white. Plant in a moist place. Desirable for border of brook or lake.

\section{LUPINUS}

perennis (Wild Lupine). Native. Grows in dry soils, with large spikes of blue flowers in spring. 20 cts. each, $\$ 1.25$ for $10, \$ 10$ per 100 .

\section{LYTHRUM}

roseum superbum. $\diamond \diamond$ Rose-purple flowers from July to September. Grows along margins of streams; quite showy. Commonly known as Loosestrife.

\section{LYSIMACHIA}

Nummularia (Moneywort). Native. Creeping leafy herb, with large yellow flowers. Quite hardy and desirable for covering shady banks and lawns where grass fails; also used for rustic vases and baskets.

\section{MERTENSIA}

virginica (Virginia Cowslip). Native. This plant grows from 1 to 2 feet high, bearing a panicle of beautiful blue or sometimes white flowers in early spring. The buds are pink. One of the choicest early spring flowers for massing in shady places or open sun, in moist but weIl drained soil, where it thrives equally well.

\section{MITELLA}

diphylla (Bishop's Cap). 囷 Native. Grows 1 to 2 feet high, producing in early spring racemes 6 to 8 inches long of delicate white flowers. Pretty for rockeries.

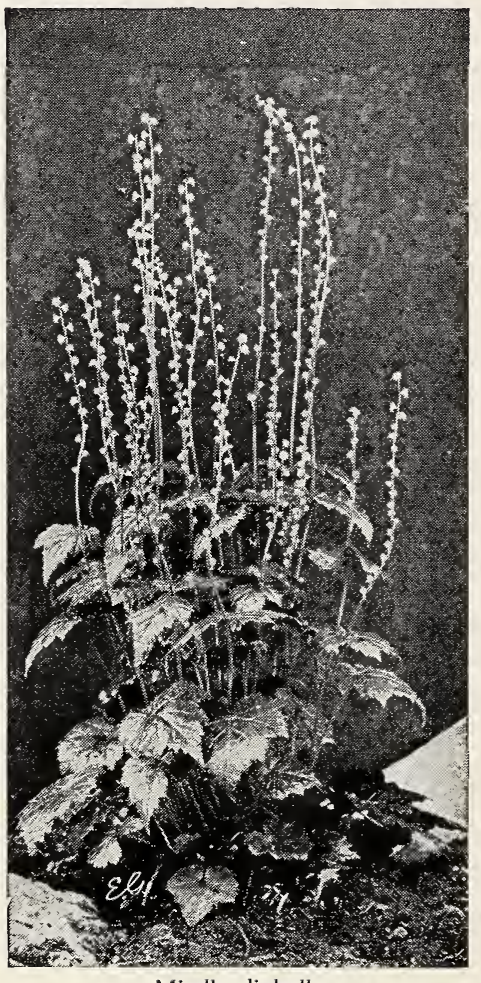

Mitella diphylla

Prices on Perennials, $25 \mathrm{cts}$. each, $\$ 1.50$ for $10, \$ 12$ per 100 , unless otherwise noted 


\section{MITCHELLAA}

repens (Partridge Berry). 因 Native. A little trailing evergreen. It forms fine mats under evergreens, and when once established, is sure to please. It does exceedingly well in winter, grown in a bell-glass. My stock is pot-grown. 25 cts. each, \$2 for 10, \$15 per 100 .

\section{MYOSOTIS}

palustris (Forget-me-not). $\diamond \diamond$ Native. Lovely light blue flowers, with yellow center. Succeeds best in moist situation.

\section{NEPETA}

Cataria (Catnip). An aromatic herb, found near dwellings. Cats are fond of it. 20 cts. each.

Glechoma (Ground Ivy; Gill). Native. Little low plant with light blue flowers in early spring. It creeps extensively and is desirable for covering moist banks. 10 cts. each, 75 cts. for 10, \$5 per 100 .

\section{PACHYSANDRA}

terminalis. See Evergreen Shrubs.

\section{PARNASSIA}

caroliniana (Grass of Parnassus). $\diamond \diamond$ Native. The flowers are white, marked with greenish veins; showy. 6 to 15 inches high.

\section{PHLOX}

amœna (Lovely Phlox). Native. One of the most charming little dwarf plants imaginable, growing only about 6 inches high, and forming a mat of evergreen foliage which is entirely covered with compact heads of bright pink flowers from April until June. A lovely springblooming plant. Prefers dry soil in sunny situations.

divaricata. Native. About 15 inches high. Flowers pale Iilac or bluish. Grows in moist humus filled soils in rocky woods.

subulata (Ground, or Moss Pink). $\diamond \mathrm{Na}$ tive. A creeping or tufted species, growing in broad mats on dry, rocky hills or sand banks. In the summer it does quite well in the border and can be used for edging or among larger plants, where it soon covers the ground.

subulata alba. $\&$ A variety of the above, with pure white flowers. Desirable for covering rocky or sandy places.

\section{POLYGALA}

paucifolia (Fringed Polygale). Native. Low-growing; purple tinted leaves and large, handsome, rose-purple flowers.

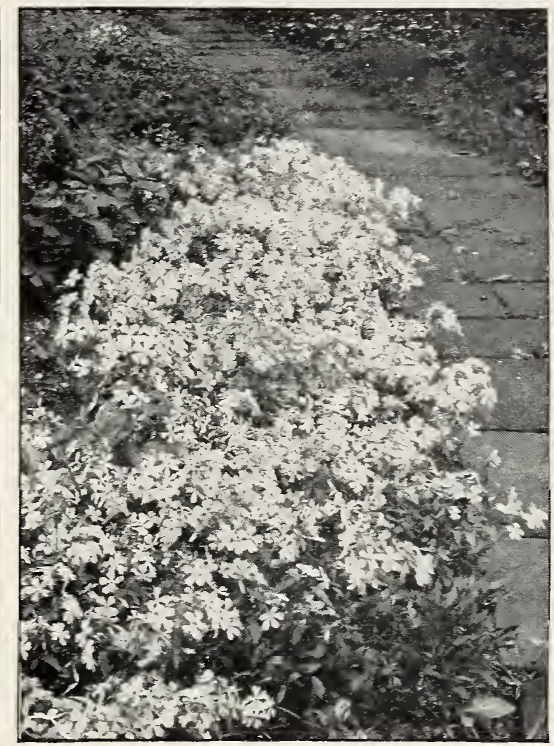

Phlox divaricata

\section{PODOPHYLLUM}

peltatum (May Apple; Mandrake). 娄 Native. A peculiar herb, with creeping rootstocks and fibrous roots. Grows a foot or more high, with large, round, seven-to-nine-Iobed Ieaves, peltate in the middle. Flowers nodding, white, 1 to 2 inches broad.

\section{POLYGONATUM}

biflorum (Solomon's SeaI). 类 Native. Grows a foot high; often seen in rich, shady places, and bearing, in June, several or many rather smaII, greenish flowers along the upper half of the stalk, followed by the black or blue berries which are quite conspicuous in autumn. Plant in moist shade; perfectly at home in the rock-garden.

majus (Giant SeaI). Native. A Iarge form of the above. $30 \mathrm{cts}$. each, \$2 for 10 , $\$ 15$ per 100.

\section{POTENTILLA}

tridentata (Wineleaf Cinquefoil). For trailing over dry banks and rockeries this prostrate Cinquefoil will be found very useful. The foliage is dark green, paler beneath; small yellow flowers in clusters are borne in June and July. 25 cts. each, \$2 for 10, \$15 per 100 . 


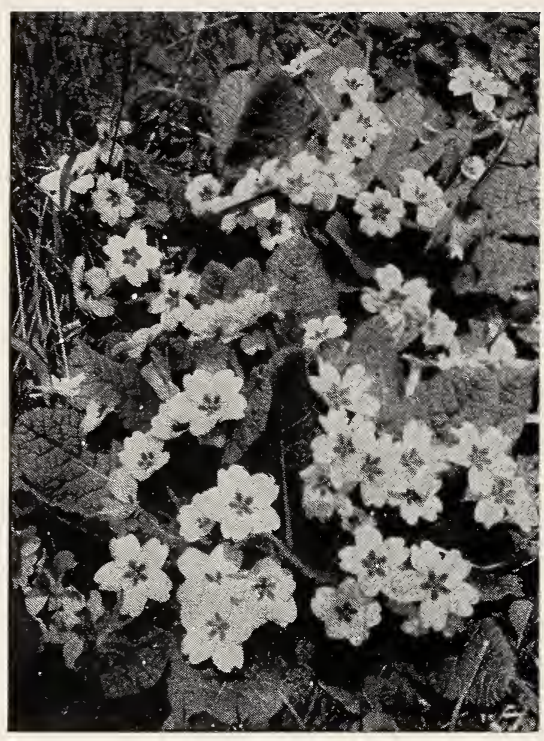

Hardy Primrose

\section{PRIMULA (PRIMROSE)}

These develop their full beauty when planted in a moist situation. For several seasons past I have met with remarkable results by growing them in my bog-garden where the moisture is constant.

acaulis. Habit of growth like the true English Primrose. Mixed colors.

Beesiana. Flowers various shades of purple with yellow eye; strong grower. 30 cts. each, $\$ 2.50$ for $10, \$ 20$ per 100 .

Polyantha. $\diamond$ The hardy garden Primrose, bearing many umbels or stems well above the clusters of leaves. Mixed sorts, mostly in garnet and yellow; good clumps.

\section{PYROLA}

elliptica (Shin Leaf). Native. A little low evergreen plant, 3 to 4 inches high, forming extended mats or ground-covers in rich shady places. Flowers white and quite attractive.

\section{SANGUINARIA}

canadensis (Bloodroot). Native. A low perennial, about 6 inches high, with pure white flowers an inch in diameter, in early spring. The large, leathery leaves appear later. Plant in rich soil, selecting, if possible, shady places or rockgarden. $15 \mathrm{c}$. each, $\$ 1$ for $10, \$ 8$ per 100 .

\section{SAXIFRAGA}

virginiensis. Native. A low perennial, 4 to 9 inches high, with a cluster of pretty white flowers appearing in early spring. Fine for rockeries. 15 cts. each, $\$ 1$ for $10, \$ 8$ per 100 .

\section{SEDUM (STONECROP)}

A class of plants particularly adapted for carpeting very dry, sandy or rocky places in open sun. The taller varicties are quite useful in the border, being quite showy.

\section{LOW VARIETIES}

acre. A little, low tufted perennial spreading on the ground. Flowers yellow; very pretty for rock-work or growing in front of the hardy border.

dasyphyllum. Small, fleshy, glaucous leaves. Flowers white. 2 inches high.

divergens. Native. A native of the Northwest; very fleshy leaves which turn a deep bronze in spring. Flowers yellow. album. From northern Asia. A low plant, 4 to 6 inches high, with linear leaves $1 / 2$ inch long. Flowers white with red centers. Useful for covering dry rocks and banks in open sun.

kamtschaticum. Grows 4 to 6 inches high with leaves rather large; runs extensively, quickly covering the soil. Flowers yellow, in late summer.

lydium. Low plants, fine for rock-work in open sun; leaves turn red in autumn.

rupestre minor. One of the finest. Turns a grayish purple in the spring. Flowers yellow.

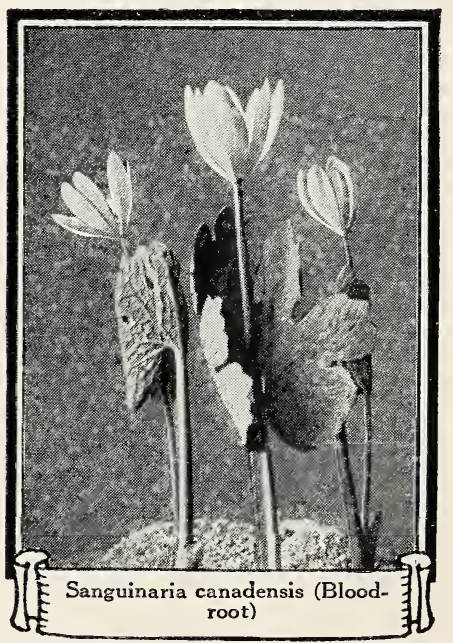

Prices on Perennials, 25 cts. each, $\$ 1.50$ for $10, \$ 12$ per 100 , unless otherwise noted 
SEDUM, LOW VARIETIES, continued

saramentosum (Stringy Stonecrop). A glabrous evergreen with long prostrate shoots, rooting at the tips. One-inch long flat flesh leaves in three's, and fiveeighth-inch bright yellow flowers all summer long. For covering rocks, rough ground or walls it is extremely useful.

sexangulare. Similar to S. acre, but the leaves and whole plant are smaller. Used for carpeting dry, bare places.

stoloniferum coccineum. A very desirable trailing variety having pink flowers. The foliage turns a deep bronze during the winter. Very fine for edgings.

\section{SEMPERVIVUM}

tectorum (House Leek). $\diamond$ A class of plants with thick leaves, of ten tinted with pink or purple. Used for rock-work or edging in dry, open places. 15 cts. each, $\$ 1$ for 10, \$8 per 100.

arachnoideum. SmaIl rosettes threaded over with white cob-web-like down.

\section{SHORTIA}

galacifolia. $\diamond$ Native. A rare evergreen species from the mountains of North Carolina. The five petals are pure white, and scalloped or notched on the edges. Flowers about an inch across in early summer. Plant in a rich, shady place. Hardy. 35 cts. each, \$3 for 10 , $\$ 25$ per 100 .

\section{SMILACINA}

bifolia (Maiantbemum bifolium). $\diamond \mathrm{Na}$ tive. Grows to 4 inches high, with small, white flowers in spring; fragrant.

racemosa (False Solomon's Seal). $\diamond \mathrm{Na}$ tive. Plants 1 to 2 feet high. Flowers white, in terminal racemes, in June and July. Found throughout New England in moist shades, usually on hillsides.

\section{SOLIDAGO (Goldenrod)}

This is an attractive genus of plants, with a large number of variable species, some of which are very beautiful. They come into flower a little before the asters.

cæsia. Native. A tall, yet slender Goldenrod, found in dry, shady places, with smooth, Ianceolate leaves. Flowers in small clusters along the upper part of the stalk, bright yellow and showy.

canadensis. $\diamond$ Native. A tall species found growing in open, sandy places. Flowers small, but very numerous, in rather flat heads. One of the finest and most prominent of all our Goldenrods. nemoralis. $\diamond$ Native. A low plant growing in dry, open places, with very bright yellow flowers in August.

In Variety. Native. For massing. \$8 per 100.

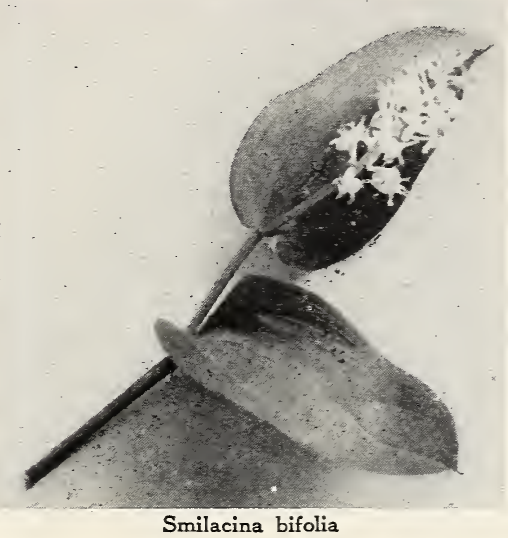

THALICTRUM

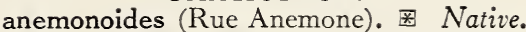
One of the earliest of our wood flowers and often seen with anemones. This plant grows about 8 inches high, from a cluster of thickened, tuberous roots. Flowers white. At home in the rockgarden or a well-drained, shady corner. Plant 4 to 6 inches apart. 15 cts. each, $\$ 1$ for $10, \$ 8$ per 100 .

dioicum. ¥ Native. Found in shaded, rich hillsides in early spring. Flowers purplish. Plant in a shaded spot where the drainage is good. 1 to 2 feet high. 15 cts. each. Cornuti (TaIl Meadow Rue). $\diamond$ Native. A stronger plant than Dioicum, often growing 4 to 5 feet high. This plant delights in a wet, open place, often along brooks. Flowers white, borne from July to September. Does well in moist soil.

\section{THYMUS}

azoricus. A creeping variety with dark green foliage; flowers pink.

lanuginosus (WooIly Thyme). A species of Thyme with smaII, roundish leaves. It is a desirable plant for edgings or in rock-work.

Serpyllum (Creeping Thyme). This makes a fine ground-cover in open, moist places on hillsides. Lavender flowers late in the summer, on slender spikes.

Serpyllum albus. A hardy sort with pure white flowers and a fine creeper to run over the rocks.

Serpyllum coccineus. Similar to above, with scarlet flowers.

\section{TIARELLA}

cordifolia (False Miterwort). ${ }^{*}$ Native. Grows about 10 inches high and bears a short raceme of pretty white flowers in May or June. Plant in rich, moist shady places. 


\section{TRADESCANTIA}

virginiana (Spiderwort). $\diamond$ Native. An old garden plant, well known for its Iong, grass-like leaves and blue or violet flowers that appear all summer. Plant in a moist, rich place, either in shade or sun.

\section{TRILLIUM}

Three-Leaved Night-Shade

A class of low perennials, having a stout and simple stem from their tuber-like root, naked, and bearing at the top three ample leaves in a whorl and a terminal flower. Trilliums belong to the lily family, bloom early in the spring, and are easily grown. They like a moist, shady situation.

cernuum (Nodding Trillium). 圈 Pure white 2-inch flowers that nod under the broad rhombic-ovate leaves. 25 cts. each, $\$ 2$ for $10, \$ 15$ per 100 .

erectum. * Native. Has broad, rhomboid leaves, with a dark purple flower. 15 cts. each, $\$ 1$ for $10, \$ 8$ per 100 .

erectum album. Similar to above, but with white flowers. 25 cts. each, $\$ 2$ for $10, \$ 15$ per 100 .

erythrocarpum (Painted Trillium). Native. White flowers painted with purple at the base; delights in cold, damp leafmold. 15 cts. each, $\$ 1$ for $10, \$ 8$ per 100 .

grandiflorum. 圈 Native. Probably the prettiest of the genus, and most generally cultivated. It grows 8 to 15 inches high; large, white flowers, of ten 2 to $2 \frac{1}{2}$ inches in length and 2 inches wide, turning to lilac-color with age. 15 cts. each, $\$ 1$ for $10, \$ 6$ per $100, \$ 40$ per 1,000 .

nivale. Native. A small, white-flowered variety, 3 or 4 inches high, blooming in the early spring.

recurvatum. 圈 Native. Leaves green, with white patches; flowers brownpurple. Beautiful and easily grown. 15 cts. each, $\$ 1$ for $10, \$ 6$ per 100 .

stylosum. Native. A southern species. Pink flowers in early spring. Very effective when planted in large colonies. 15 cts. each, $\$ 1$ for $10, \$ 8$ per 100 .

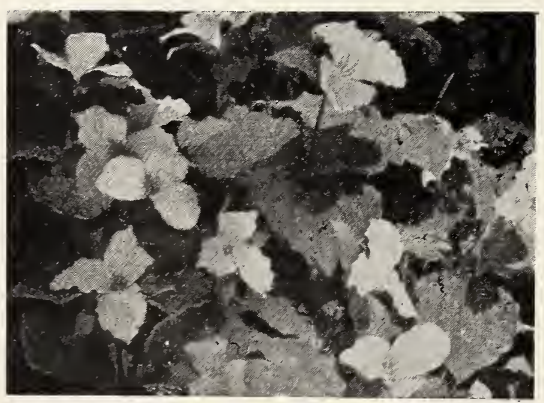

Trilium grandiflorum

\section{TUNICA}

Saxifraga. Grows about a foot high, with numerous spreading leaves. Flowers small, but literally covering the plant, rosy white, pink or purple in color. Fine for open border or rockgarden.

\section{UVULARIA}

perfoliata. 圈 Native. Thrives in damp soils, and requires shade. Flowers light yellow. 15 cts. each, $\$ 1$ for $10, \$ 8$ per 100.

sessilifolia. 圈 Native. Similar to the preceding, only the leaves are sessile instead of clasping. AII these Uvularias are easily cultivated and quite pretty. 15 cts. each, $\$ 1$ for $10, \$ 8$ per 100 .

\section{VERNONIA}

noveboracensis (Ironweed). $\diamond$ Native. Vigorous growing perennials, 3 to 5 feet high, with very showy purple flowers in small heads in autumn. Effective as single specimens or grown in clumps near water or very moist ground. 25 cts. each, $\$ 2$ for 10 .

\section{VERONICA}

prostrata (HarebeII SpeedweII). A rockgarden plant with prostrate stems rambling about. Large deep blue flowers produced abundantly in June.

\section{VINCA}

minor (Common PeriwinkJe). \& A $*$ Also known by name of Blue Myrtle. A most beautiful evergreen trailing plant with large blue flowers. Hardy and desirable in dry shade to cover barren places. 25 cts. each, \$2 for 10, \$15 per 100 .

\section{VIOLA}

The Violets are, for the most part, among our first spring flowers. They furnish an abundance of bloom, a variety of colors, and are easily grown.

blanda (Sweet White Violet). $\diamond \diamond$ Native. Flowers slightly fragrant. Plant in damp, open places in spring. 20 cts. each, $\$ 1.25$ for $10, \$ 10$ per 100 .

canadensis. 图 Native. Grows 1 to 2 feet high, with heart-shaped leaves and whitish flowers tinged with purple. A moist, shady situation is desirable for its cultivation. Blooms in the greatest profusion from early May to August.

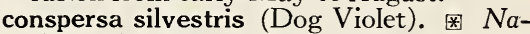
tive. A pretty, many-flowered blue Violet, 6 inches high, branching and forming little clumps. For best results should be planted in moist, shady places. 20 cts. each, $\$ 1.25$ for $10, \$ 10$ per 100 .

cornuta (Horned Pansy). A An old garden plant of much merit, with sweetscented, bright lavender flowers in spring; hardy in wet, open places. 


\section{VIOLA, continued}

cornuta alba. $\diamond$ A pure white variety of good form; a great bloomer from spring through the season. 25 cts. each, \$2 for $10, \$ 15$ per 100 .

cucullata (Common Blue Violet). ※ Native. A vigorous plant, each leaf and flower-stalk growing on a long stem from the thickened or tuberous root. Flowers deep or pale violet-blue or purple, single. It grows in damp shady places. 15 cts. each, $\$ 1$ for $10, \$ 8$ per 100 .

Johnny-jump-ups. \& Little Violet found in old gardens; bright yellow and purple flowers, sometimes called "Johnny-jumpups." 15 cts. each, \$1 for 10 .

lutea (European Yellow Violet). $\diamond$ Attractive yellow flowers, similar to $V$. cornuta in shape, with fine black stripes at base of petals. Dense growing, 2 to 6inch-tall plant; profuse bloomer, early spring till frost. Half-shade.

odorata. $\diamond$ The common Sweet English Violet. Single, but very fragrant.

palmata. Native to the Eastern United States. The flowers are blue, with now and then a white specimen.

pedata (Bird's-foot Violet). $\diamond$ Native. Leaves all divided. Large, handsome, pale or deep purple or blue flowers in
Viola pedata, continued

summer. Delight in a dry, sandy soil in open sun. Spring or early summer. One of the very best of our wild Violets and satisfactory to grow by reason of its great flower-bearing quality. Fine, large clumps. 25 cts. each, $\$ 1.25$ for 10 , $\$ 10$ per 100 .

pedata bicolor. Native. A variety with the two upper petals very much darker. 25 cts. each, $\$ 2$ for 10 , \$15 per 100 .

pubescens. $\diamond$ Native. Flowers yellow, veined with purple. Found in New EngIand, in rather dry soils, in shade, in early summer. 6 to 12 inches high.

rotundifolia. $\diamond$ Native. A low Violet, 2 to 3 inches high, with large leaves, flat on the ground, growing on moist, mossy banks near mountain brooks. Early spring. $15 \mathrm{c}$. each, \$1 for 10, \$8 per 100. septentrionalis. $\diamond$ Native. An albino, growing 6 to 10 inches high in early summer. Strong vigorous grower, with masses of well-developed, dark green leaves. The flowers are white, with purple in the throat, standing up weIl above the leaves and covering the plant with its masses of bloom. It does weII in the rich, moist border or partially shady nook; not fragrant; forms large clumps.

\section{BOG-PLANTS}

To the group of plants which can be conveniently classed as Bog-PIants belong some of the most interesting varieties of our American flora. These require a damp situation. It is not essential that the amount of moisture present be excessive yet it must be constant. If one does not have the natural conditions for growing this class of material, an artificial bog-garden can be constructed. Those interested in constructing such a garden should write us for full details which will be gladly given.

Bog-Plants, 25 cts. each, $\$ 1.50$ for $10, \$ 12$ per 100 , unless otherwise noted

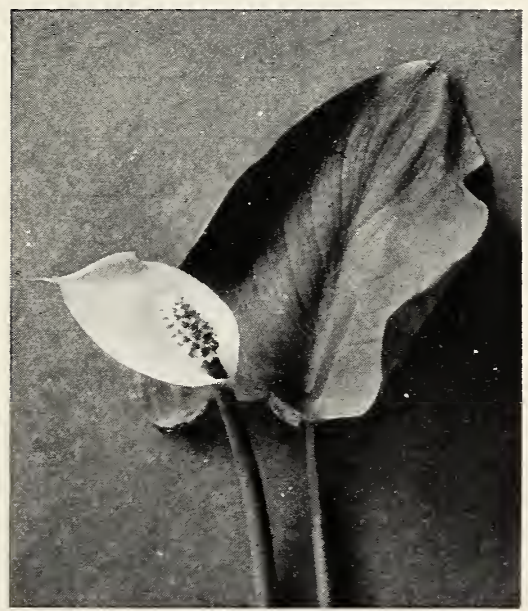

Calla palustris

\section{ACORUS}

Calamus (Sweet Flag). Native. Grows in low, wet places. Leaves light green, 1 to 3 feet long. The root-stock has an aromatic flavor weIl known to people of New England. Desirable for shallow Iakes and wet places.

\section{CALLA}

palustris (American CaIla). Native. Similar to the cultivated sort, only smaller; easily grown in the bog. 15 cts. each, \$1 for $10, \$ 8$ per 100 .

\section{CALTHA}

palustris (Marsh Marigold). Native. 6 to 15 inches high. Flowers bright yellow in spring. A very showy plant in wet places, both in sun and shade. It can also be planted in brooks, in water 2 to 4 inches deep; for massing, plant 1 foot apart. It can also be grown in pots for forcing. 15c. each, $\$ 1$ for $10, \$ 8$ per 100.

Prices on Perennials, 25 cts. each, $\$ 1.50$ for $10, \$ 12$ per 100 , unless otherwise noted 


\section{CYPRIPEDIUM}

spectabile. See Orchids.

\section{DROSERA}

filiformis (Thread-leaved Sundew). Native. A little bog-plant, with long threadlike leaves, covered with short, red hairs. Flowers rose-purple, along the upper part of the stem. Wet, sandy soils. 4 to 8 inches high.

longifolia. Native. Similar to the above, only the leaves are narrower. Bog. 15 cts. each, \$1 for 10 .

\section{HABENARIA}

ciliaris. Native. See Orchids.

\section{JUNCUS}

effusus (Bog Rush). Native. Stem round, dark green, 2 to 4 feet high, bearing near the top a cluster of small, inconspicuous flowers. Quite desirable for wet, marshy places, where it soon establishes itself, forming good clumps. 15 cts. each, $\$ 1$ for $10, \$ 8$ per 100 .

\section{IRIS}

Pseudacorus (Yellow Iris). Native. Quite large, bright yellow flowers on stems 2 feet high.

\section{LOBELIA}

cardinalis. Native. See page 16.

\section{MENYANTHES}

trifoliata (Buck Bean). Native. A pretty little bog-plant, growing in moss. Has large, pure white flowers, covered on the upper surface with frost-like beards in early spring. Fine for the bog-garden. 15 cts. each, $\$ 1$ for $10, \$ 8$ per 100 .

\section{POGONIA}

ophioglossoides. See Orchids.

\section{NES $Æ A$}

verticillata. Native. A pretty little water shrub, found along the margins of lakes in shallow water or wet ground, with clusters of smaII, rose-purple flowers. Leaves are brightly colored in autumn and make a bright spot in the landscape. 20 cts. each, $\$ 1.25$ for $10, \$ 10$ per 100 .

\section{SARRACENIA}

purpurea (Pitcher Plant). Native. This plant usually sends up one flower-stalk 6 to 18 inches high, bearing a single, deep purple flower an inch or more in diameter. Leaves pitcher shaped, curved, ascending, 2 to 6 inches in length, greenish, with purple veins, or reddish purple. Plant in a wet place.

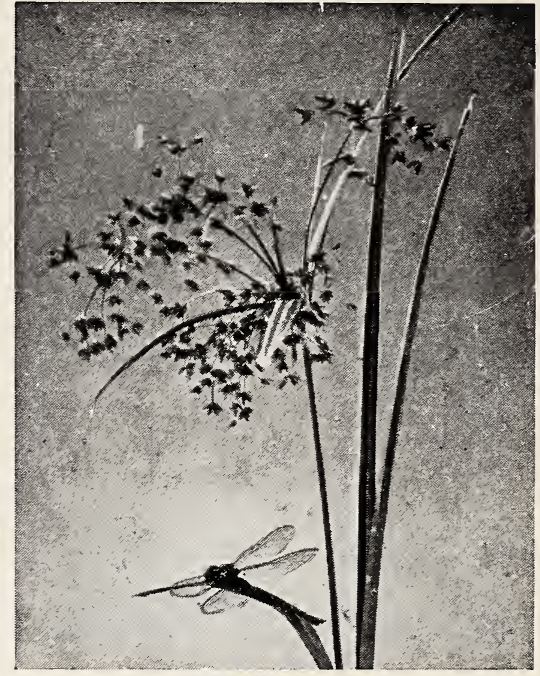

Scirpus atrovirens

SARRACENIA, continued

flava (Trumpet-Leaf). Native. Flowers and leaves yellow, the former 4 to 5 inches wide, leaves 2 feet long. Often hundreds of insects are found in a single pitcher; easy to grow in the bog.

rubra (Red-flowered Trumpet-Leaf). $\quad N a$ tive. Pitchers red-veined; flowers reddish purple.

\section{SCIRPUS}

atrovirens (Marsh Sedge). Native. Fine for moist or wet places. 1 to 3 feet high. 15 cts. each, $\$ 1$ for $10, \$ 8$ per 100 .

\section{TYPHA}

latifolia (Cat-tail). Native. A plant found in wet places, growing 2 to 4 feet high. Leaves long, grass-like; flowers grow in a spike. Picturesque when growing on the margins of small streams and as a border for ponds. For massing, plant 2 feet apart.

\section{VACCINIUM}

macrocarpon (American Cranberry). $\mathrm{Na}$ tive. The common Cranberry of commerce, easily grown in the bog or any moist situation. Good clumps, 15 cts. each, $\$ 1$ for 10 , $\$ 8$ per 100 .

\section{VERATRUM}

viride (American White Hellebore). $\mathrm{Na}$ tive. Thrifty plants, large, broad, green leaves, nearly a foot long. Grows 2 to 4 feet high, bearing many small, yellow, or greenish flowers at top. At home in a moist or wet, black peaty soil. 


\section{NATIVE ORCHIDS}

Native Orchids are universally admired. These beautiful gems of our woodland can, in the majority of cases, be easily grown; some require special conditions. Those who are in doubt as to the proper variety to select for growing under certain conditions should write us for further particulars.

Native Orchids, 25 cts. each, $\$ 1.50$ for $10, \$ 12$ per 100, unless otherwise noted

\section{CYPRIPEDIUM}

acaule (Lady's Slipper; Moccasin Flower). Native. This is often called the Red Lady's Slipper, but the flower is rosepurple in color. The plant sends up two broadish green leaves from the base, and from between them comes a stalk about a foot high, bearing a single Iarge, showy flower. Plant in a well-drained soil, with some leaf-mold. This does quite weII in pots. Each $10 \quad 100$

1 to 2 -crown plants... $\$ 0 \quad 25 \quad \begin{array}{lllll}\$ & 00 & \$ 1500 & 0\end{array}$ 3 to 5-crown plants... $50 \quad 400$

pubescens. In this variety the petals are usually slightly twisted and are much narrower than the sepals. The flowers, which come in May and June, are pale yellow in color. The plant is found under natural conditions as far north as Newfoundland, and has a southern range into lower Georgia.

$\begin{array}{crrr}\text { Each } & 10 & 100 \\ \text { to } 2 \text { crowns..... \$0 30 } & \$ 2 & 50 & \$ 2000 \\ 40 & 40 & 4000\end{array}$

3 to 4 crowns..... $50 \quad 450 \quad 4000$

Large clumps, 5 to

8 crowns...... 150

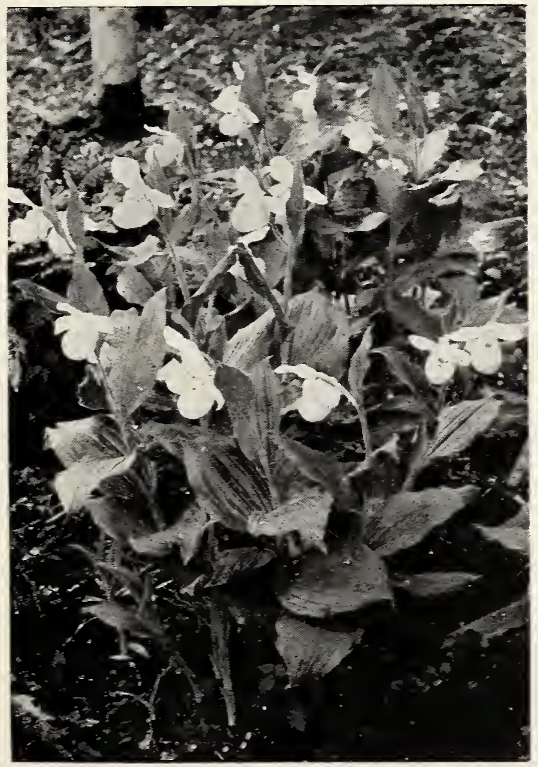

Cypripedium spectabile
CYPRIPEDIUM, continued

spectabile (Showy Lady's Slipper). $\mathrm{Na}$. tive. The finest and most showy of aII our Orchids. It grows about 2 feet high, bearing along the stalk several rather Iarge, roundish leaves, and on top one or two quite large rose-purple or nearly white flowers. It is a bog-loving plant, yet does exceedingly well in a moist and partly shaded bed of peat or leaf-mold. Nothing can be more charming than masses of this plant in a cedar swamp, its natural home.

$\begin{array}{crrrr}\text { Each } & 10 & 100 \\ 1 \text { to } 2 \text {-crown plants.. } \$ 0 ~ 35 & \$ 300 & \$ 2500 \\ 3 \text { to } 4 \text {-crown plants.. } & 75 & 6 & 50 & 6000\end{array}$

$\begin{array}{ll}3 \text { to } 4 \text {-crown plants. . } & 75 \\ 5 \text { to } 8 \text {-crown plants. } 1 & 50\end{array}$

\section{GOODYERA}

pubescens (Rattlesnake Plantain). Native. Leaves white, reticulated, clustered at the bottom. Stem leaflets about a foot high, bearing a short spike of white flowers. Plant in a shady place, with leaf-mold. 8 to 15 inches high. 15 cts. each, \$1 for 10 , \$8 per 100 .

repens. Native. Flowers white; leaves smaller and markings not so bright as the preceding. Thrives in a sheltered leaf-mold bed. 15 cts. each, $\$ 1$ for 10.

\section{HABENARIA}

ciliaris (Yellow-fringed Orchis). Native. The flowers are brilliant orange, with the petals fringed at the apex. A charming plant blooming in August. 25 cts. each, \$2 for 10, \$15 per 100 .

psycodes. CommonIy called the Small Purple Fringed Orchid. The plant is seldom more than 3 feet high and bears many lilac-colored blooms which are quite fragrant. July and August. 25 cts. each, \$2 for $10, \$ 15$ per 100 .

\section{POGONIA}

ophioglossoides. Native. A little fibrousrooted plant, found growing in sphagnum moss and wet places in leaf-mold. The solitary (sometimes paired), pale rose or white fragrant flowers are borne on 4 to 10 -inch stems. Plants may be colonized in wet meadows. $25 \mathrm{cts}$. each, $\$ 1.50$ for $10, \$ 12$ per 100. 


\section{AQUATIC PLANTS}

Plants grown in water 2 to 3 feet below the surface; always below the frost-line. Aquatic Plants, 35 cts. each, $\$ 2$ for $10, \$ 20$ per 100 , unless otherwise noted

\section{BRASENIA}

peltata (Water Shield). Native. An aquatic growing in 1 to 6 feet of water. Leaves entire, floating, 1 to 3 inches broad, greenish or purplish. Flowers smaII, duIl purple, appearing on the water's surface.

\section{LIMNANTHEMUM}

lacunosum (Floating Heart). Native. A pretty little aquatic, with blotched leaves and white flowers all summer. Plant in water 2 to 5 feet deep. 25 cts. each, \$2 for 10, \$12 per 100.

\section{NASTURTIUM}

officinale (Hardy English Water-Cress). Native. A well-known hardy perennial aquatic, easily grown in any stream. Flowers white. 25 cts. each, $\$ 1.50$ for 10 , $\$ 12$ per 100.

\section{NUPHAR}

advena (Common Yellow Lily). Native. Has large leaves and single yellow flowers through the summer. Found in still water, 2 to 5 feet deep. Easily grown.

\section{NYMPHAA}

odorata (Sweet-scented Water-Lily). $\mathrm{Na}$ tive. Where no pond or slow-flowing stream is near at hand, the plant may be grown in a Iarge tub partly filled with rich mud or clay, the roots planted in this and the tub filled with water. For planting in a lake, a stone can be tied to the root and thrown to the place where they are to be grown, or pressed into the mud with a stick. Plant in water 2 to 5 feet, or below frost.

\section{PELTANDRA}

virginica (Water Arum). Naiive. Leaves on long petioles, sometimes like a calla in outline, with greenish flowers, growing a foot or more out of the water. Plant in water, a foot deep in mud.

\section{PONTEDERIA}

cordata (PickereI Weed). Native. Flowers blue; grows in water about a foot deep, quite often in sand, in ponds or slow streams. Flowers smaII but numerous, raised 8 to 12 inches above the water. For massing, plant $1 \frac{1}{2}$ feet apart.

\section{HARDY VINES AND CREEPERS}

AMPELOPSIS quinquefolia (Virginia Creeper). Native. Each

2-year stock .......................... 5035

APIOS tuberosa (Wild Bean). Native................ 15

ARCTOSTAPHYLOS Uva-ursi (Bearberry). Native Evergreen trailer, easily established in light soil..........

CELASTRUS scandens (Bittersweet). Native. 2 to 3 feet.....

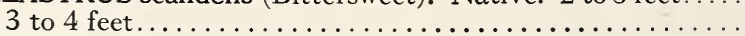

CLEMATIS virginiana (Virgin's Bower). Native..........

EPIGÆA repens. The weIl-known Trailing Arbutus, which is probably the most popular of aII wild flowers. The flowers are both white and rosy pink, and vary somewhat in size. It is aImost impossible to succeed with plants taken from the fields, but success is reasonably sure with nursery-grown plants. Established clumps

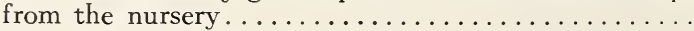

RUBUS hispidus (Running Swamp Blackberry). Native.... .

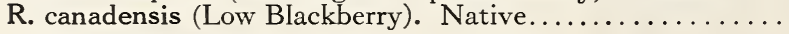

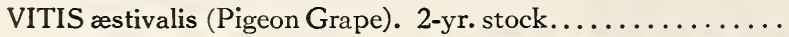

\section{0}

35

50

30

10

$\$ 300$

100

100

$\$ 2500$

100

\begin{tabular}{|c|c|}
\hline & 2250 \\
\hline 200 & 1500 \\
\hline
\end{tabular}

75

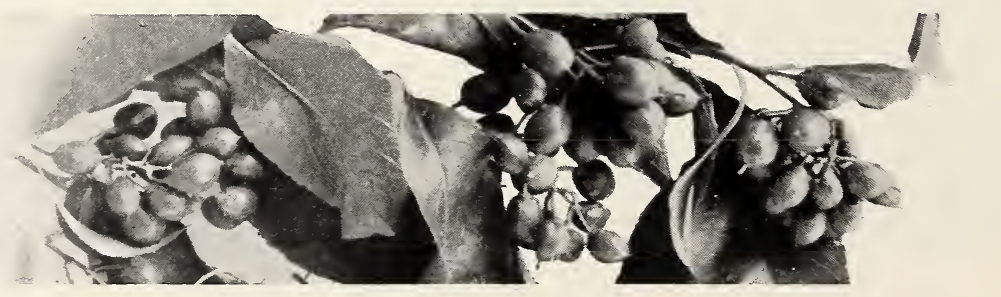




\section{CONIFEROUS EVERGREENS}

Coniferous Evergreens have a place all their own. Their spire-like habit puts the "jazz" into an otherwise monotonous sky-line. Besides, there are hardly any two of the same color, and, with a few exceptions, those colors do not vary much the year roundunless the color is lighter in the spring when new growth is made. A few assume attractive bronzy tones in fall. Conifers impart a feeling of substantial desirability to a home or garden surrounded by them, or in which they are freely used. For foundation plantings, covering banks, waIls and other objects, they are extremely useful.

All prices are f. o. b. Southwick, Mass. Packing charges are included-no extras.

JUNIPERUS communis (Common Juniper). Native. Usually a shrub with spreading, sometimes prostrate branches curving upward near the ends. Beautiful as a ground-

8 to 12 inches........................ Each 00

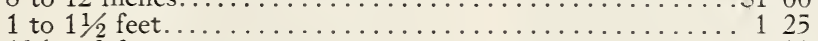

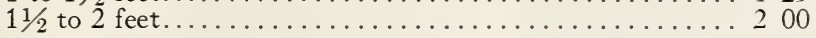

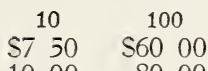

$1000 \quad 8000$

J. virginiana (Red Cedar). Native. Tapering trees of great beauty and hardiness, sometimes 100 feet tall. Densely clothed in green or bronze-green foliage.

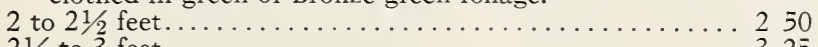

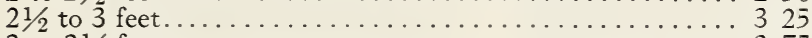

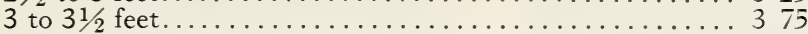

THUYA occidentalis (American Arborvitæ). One of the few conifers that are perfectly hardy in New England. Attains a height of 60 feet, is pyramidal in outline, with bright green foliage. Assumes bronzy tones in winter.

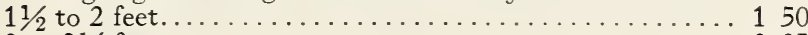

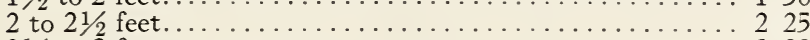

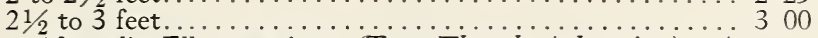

1250

2000

2750

T. occidentalis Ellwangeriana (Tom Thumb Arborvitæ). A slow-growing, broad, pyramidal tree that never gets very high. Desirable for foundation plantings.

15 to 18 inches............................. 150

18 to 24 inches............................. 200

T. occidentalis ericoides (Heath Retinospora). Dwarf, gilobose, or broadly pyramidal tree; slender branches clothed with needle-shaped leaves, duII green above, grayish green beneath, which assume a brownish tint in winter.

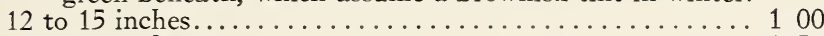

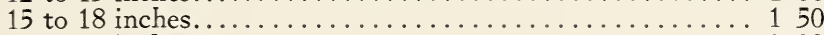

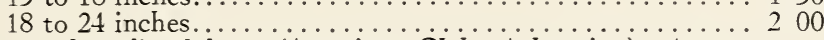

T. occidentalis globosa (American Globe Arborvitæ). A very formal and striking plant. In outline a symmetrical giobe; bright green foliage. Low, and slow-growing.

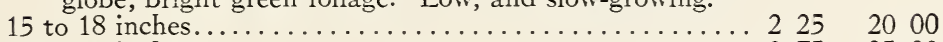

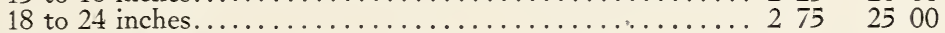

TSUGA canadensis (Canadian Hemlock). Native. One of the best six conifers for planting in southern New England, according to the Arnold Arboretum. A most handsome ornamental tree, growing 60 to 70 feet high, sometimes 100 feet. Makes a good hedge.

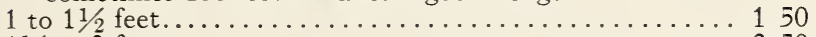

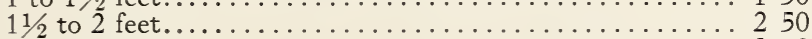

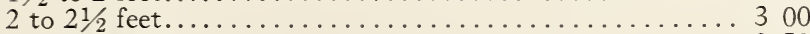

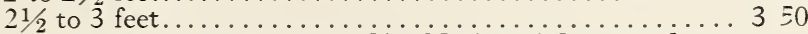

1750

T. caroliniana (Carolina Hemlock). Native. The most beautiful of all the Hemlocks, and, according to the Arnold Arboretum, among the six most desirable conifers for planting in southern New England. Has successfully stood New England winters at the Arnold Arboretum.

18 to 24 inches............................ 250

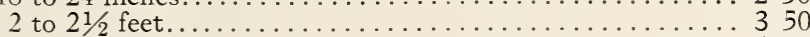

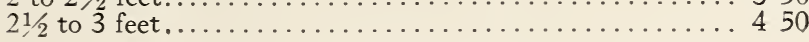




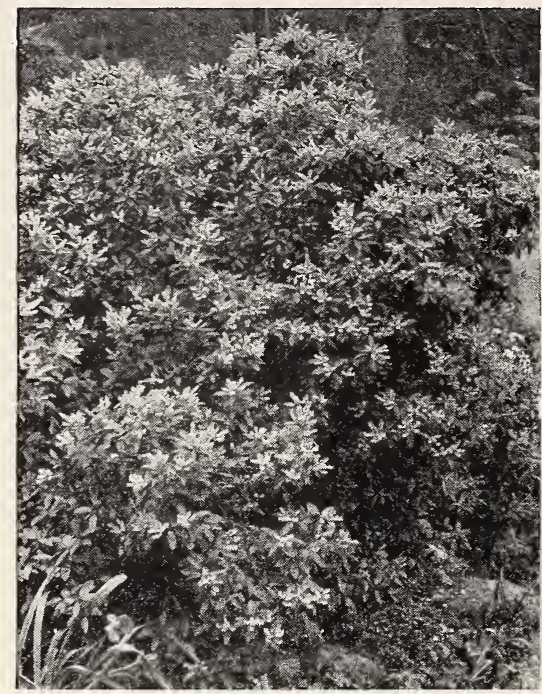

Andromeda floribunda

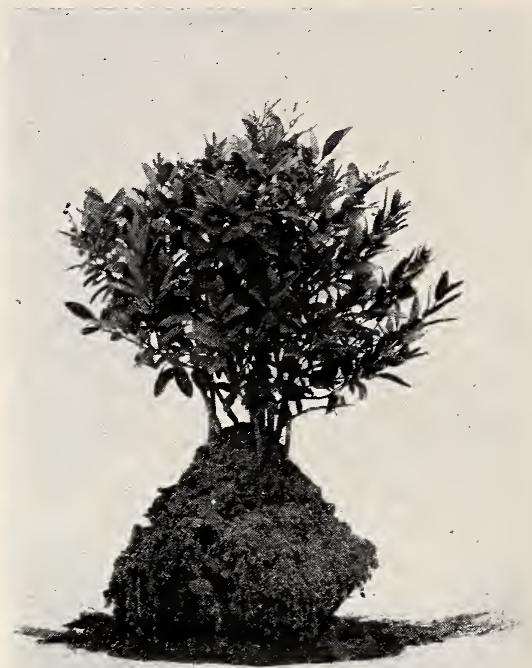

Andromeda floribunda, 15 to 16-in. grade

\section{EVERGREEN SHRUBS}

There is a luxuriance about Broad-leaved Evergreens that is very hard to describe, but which everyone feels and adnires when they behold them. Their dark green, glossy leaves are always attractive, and, as foundation plantings about the house, they impart a feeling of warmth in winter and of coolness in summer.

Prices include careful balling, burlapping, and packing. Prices f. o. b. Southwick

ANDROMEDA (Pieris) floribunda (Lily-of-the-Valley Shrub).

Native. Beautiful, hardy shrub. In early April is covered with showy spikes of white flowers. Very desirable for edging rhododendron beds. Each

12 to 15 -inch spread....................\$2 75

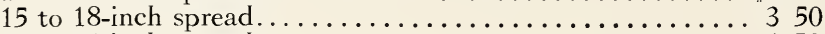

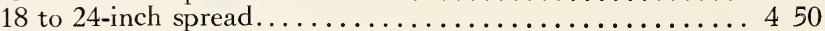

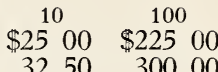

$3250 \quad 30000$

CALLUNA vulgaris (Heather). Here is something distinctly out of the ordinary for the garden. In Iate July or early August the plants are a mass of color. Thrives on poor soils, the only requirements being a sunny situation and severe pruning in the early spring.

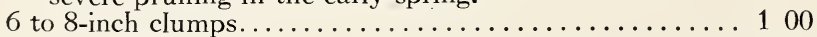

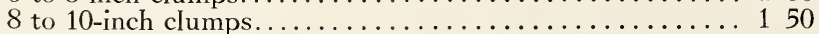

CASSANDRA (Chamædaphne) calyculata (Leatherleaf). Native. An exceedingly hardy shrub which thrives whether in upland soil or growing with roots and stems immersed in water. Low, spreading habit; profusion of delicate white flowers in early spring.............

DAPHNE Cneorum (Rose Daphne). A most attractive, dwarf, almost prostrate shrub. In May, and again in August, it bears beautiful flower clusters of a delightful shade of pink. For rock-gardens and the edges of borders it is very desirable.

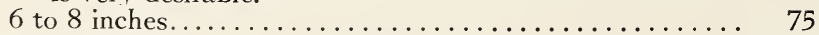

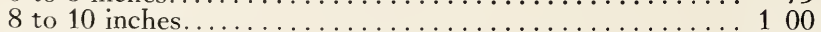

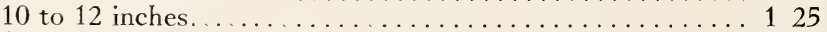

12 to 15 inches .........., 200 


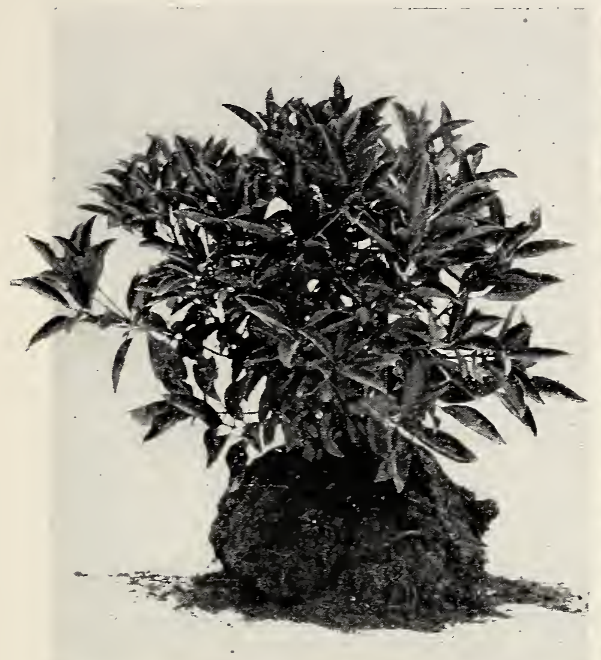

Kalmia latifolia. A fair specimen from my fields

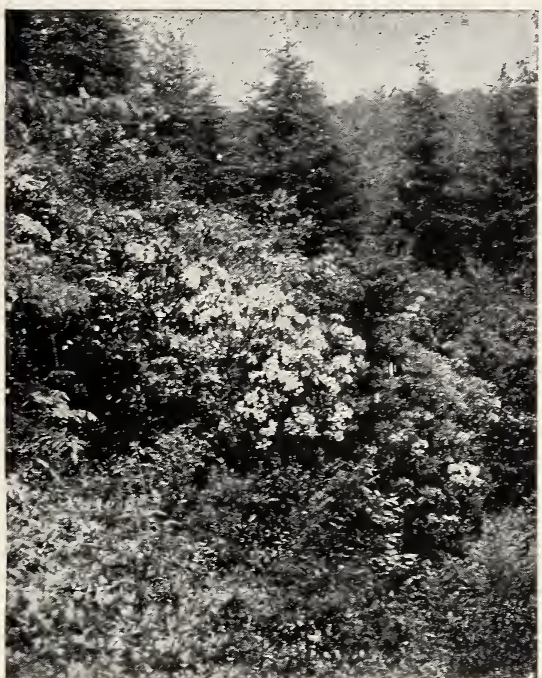

Kalmias in native haunts

ILEX glabra (Inkberry). Native. One of the best broad-leaved evergreens for New England. A broad, round-topped shrub with small, lustrous leaves. The inconspicuous flowers are followed by small black fruits, more or less concealed by the foliage, which hangs on all winter.

12 to 15 inches.......................... \$2 $00 \quad \$ 1750$

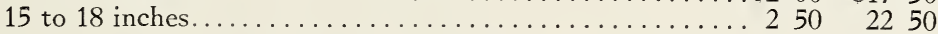

KALMIA glauca (Bog Kalmia). Native. Not particular whether it has a sweet or sour soil, this low-spreading evergreen thrives in boggy conditions as weIl as on the uplands. Rose-colored or purplish flowers in May or June. Height 2 feet.

1 foot

K. latifolia (Mountain LaureI). Native. When in full bloom in June this is one of the most glorious Amer can shrubs. Its wheel-shaped, rosy pink or white flowers are so abundantly borne that they almost completely hide the dark green, glossy foliage.

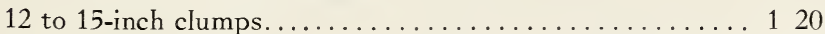

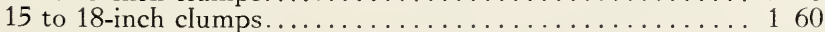

$1000 \quad 9000$

$1500 \quad 12500$

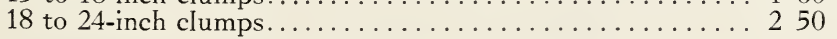

$2250 \quad 20000$

LEUCOTHOE Catesbæi (Drooping Leucothoë). Native. One of the hardiest, broad-leaved evergreens for this climate. The long, spreading, arching stems are clothed with long-pointed, handsome, deep green leaves, 4 to 7 inches long, and the attractive white-flowered racemes are borne in May. A fine shrub for groundcover, requiring moist soil and shaded situations. It grows freely under the protection of evergreens, in a shrub border, or at the edge of a woodland. Height 6 feet.

12 to 18 -inch bushy plants.................. $100 \quad 850 \quad 7500$ 
LEDUM latifolium (Labrador Tea). Native. This attractive little shrub, 1 to 3 feet high, thrives in sun or part shade in the border or even in swampy ground, but prefers a sandy or peaty soil. Fine as an edging for rhododendrons or other tall, broad-leaved evergreens. White flowers in June.

1 to $11 / 2$ feet.

$1 \frac{1}{2}$ to 2 feet, extra-selected specimens.

PACHYSANDRA terminalis (Japanese Pachysandra). The best ground-cover under shrubs of all kinds. Grows only 6 inches high, spreading by underground stems, and has dark green foliage. The flowers are incon-

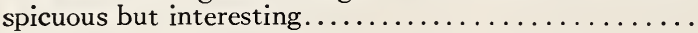

\section{HOW TO GROW RHODODENDRONS AND AZALEAS}

Rhododendrons and Azaleas must be given careful attention after planting, for oftentimes, fine, thrifty stock fails to produce the desired results because of the lack of after-care. The soil must be thoroughly prepared by deep spading, making it porous, and after the plants are set the ground must be given frequent waterings and a heavy mulch of Ieaves applied; the Iatter will tend to retain the moisture in the soil.

Soils. AII members of the heath family, including broad-leaved evergreens and azaleas, require a soil showing an acid reaction. Because of this special requirement, many sections of the country have thus far been prevented from enjoying the beautiful display furnished by rhododendrons, kalmias, and azaleas. In sections where the soil shows an alkaline reaction, gardeners need no Ionger despair, because, by special soilpreparation, these gorgeous representatives of our native pants can be made to thrive. Remove the soil where a planting is contemplated, refilling with humus which shows an acid reaction. In this humus, rhododendrons, azaleas, and other members of the heath family can be planted with a fair assurance of satisfactory results. Should the soil in

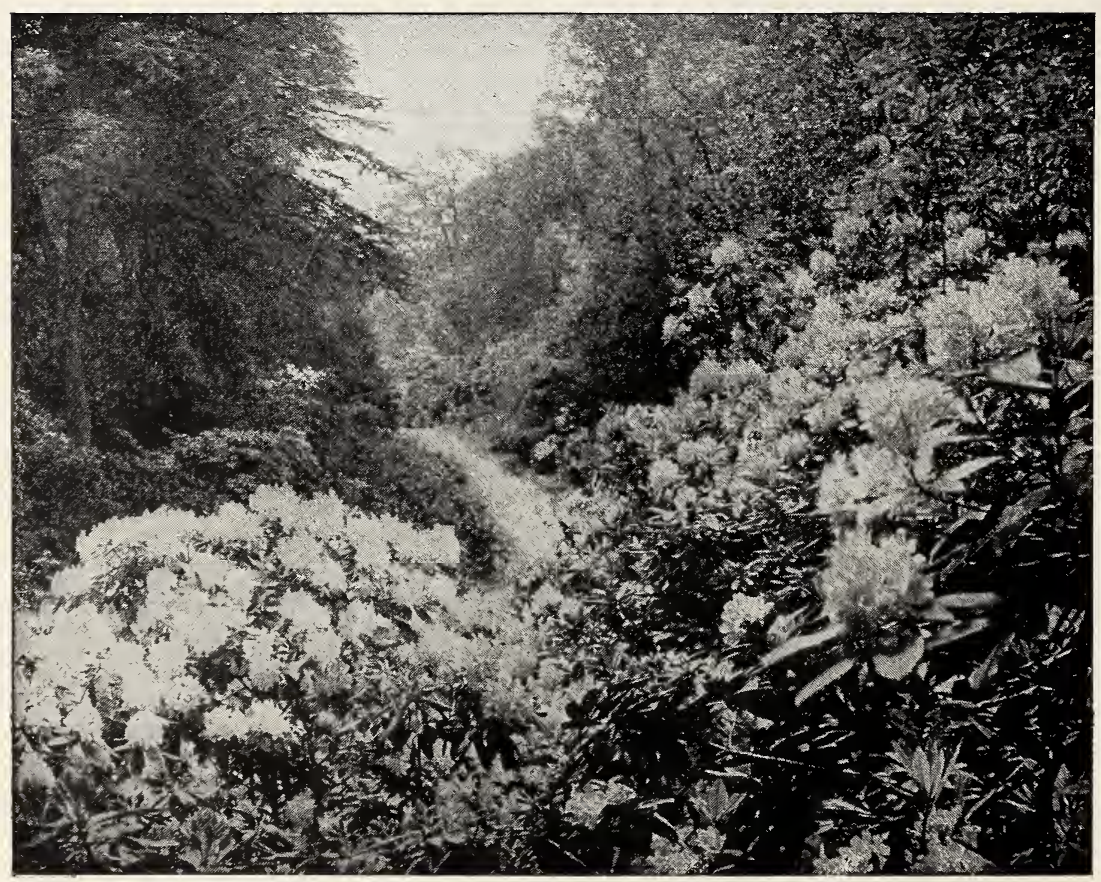

Rhododendron Catawbienșe is one of our loveliest native evergreen shrubs 
your garden be neutral-neither acid nor alkaline-an application of one pound of a commercial form of tannic acid, diluted in twenty-five gallons of water, and sprinkled over a piece of ground 10 by 25 feet, will create favorable conditions. Frequent waterings with a solution of one part of commercial tannic acid to fifty parts of water will keep the soil in an acid condition, furnishing the requirements for successfully establishing and growing this class of plant material.

Each fall a 5-inch mulch of oak leaves, or foliage from other hardwood trees, should be applied to the ground in which the broad-leaved evergreens are growing. Allowing this to rot will usually maintain an acid condition.

\section{ACID HUMUS FROM PEAT-BEDS}

To those who live in a section where acid humus cannot be advantageously obtained, I am pleased to offer special soil, shipped direct from the bogs of New Jersey, at the following prices: Bulk carload, \$9 per ton; less than carload, put up in 100-lb. bags, $\$ 20$ per ton; five 100-lb. sacks, \$6, all f. o. b. shipping point.

RHODODENDRON carolinianum (Carolina Rhododendron). Native. The most beautiful of the native Rhododendrons, growing 6 to 8 feet high. The plants are well clothed with dark green leaves, rusty below, and produce, in early May, a wealth of unusually large, pale, rose-pink flowers in good-sized clusters. Without doubt one of the best of aII broad-leaved evergreens, and thrives in full sun or partial shade.

Each $10 \quad 100$

9 to 12 -inch clumps. .......................\$2 $00 \quad \$ 17 \quad 50 \quad \$ 15000$

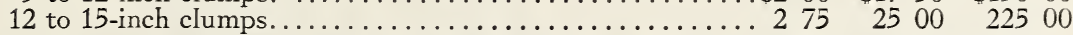

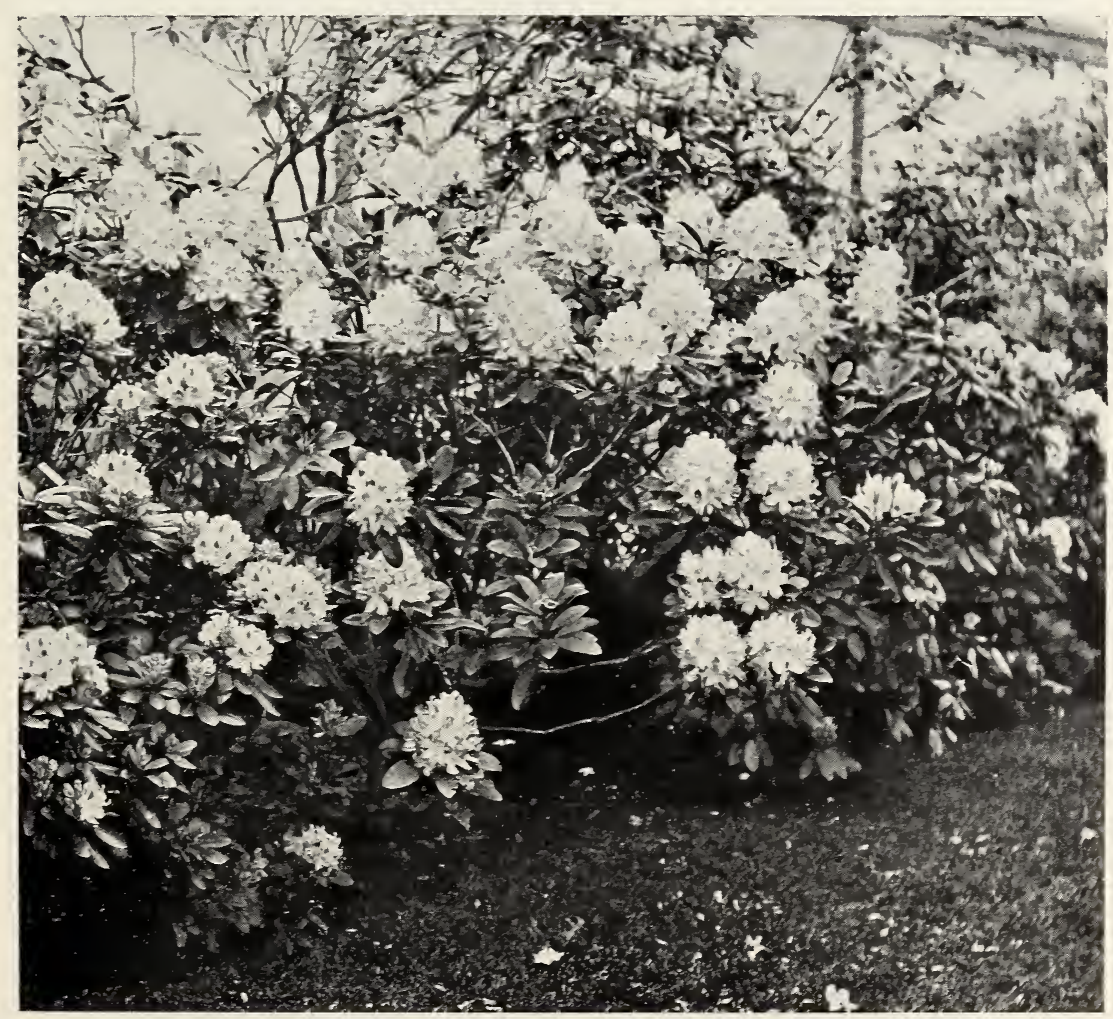

Under favorable conditions Rhododendrons will come to be large sized shrubs, and a mass of flowers 


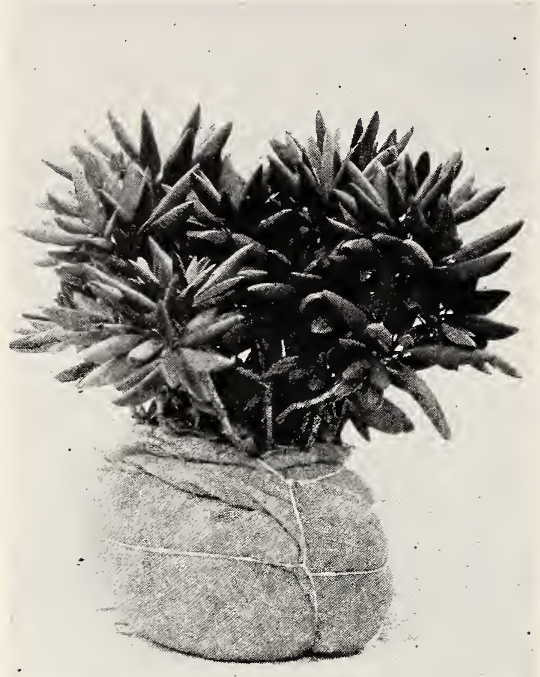

Rhododendron catawbiense compacta

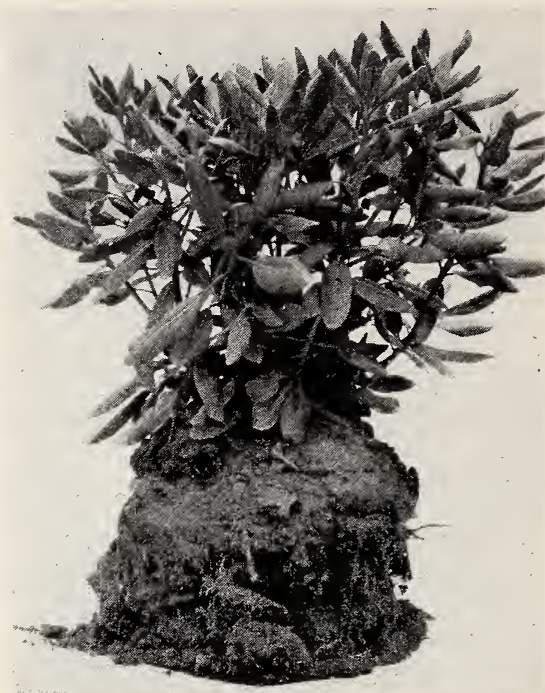

Rhododendron catawbiense, 18-inch grade

RHODODENDRON, continued

R. carolinianum album (White Carolina Rhododendron). Blooming a little before the pink form, this white variety is covered with clusters of white flowers.

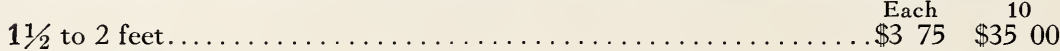

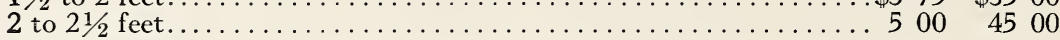

R. catawbiense (Catawba Rhododendron). One of the most beautiful native shrubs and the hardiest of aII the Rhododendrons. In June every branch has a Iarge cluster of $1 \frac{1}{2}$-inch broad, rosy purple blooms. The foliage is the most handsome of any Rhododendron.

1 to $11 / 2$-foot clumps...................... $\$ 200 \$ \$ 1750$

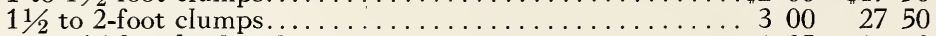

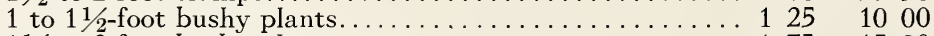

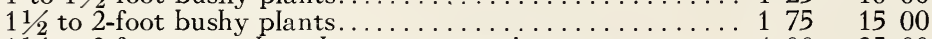

$11 \frac{1}{2}$ to 2 -foot, extra-broad, compact specimens......... 4003500

R. catawbiense compacta. For positions exposed to sun and wind, these dwarfed forms are superb. The plants are more woody and the dark green foliage smaller than in the preceding variety.

Each

10

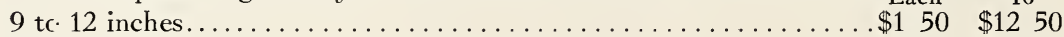

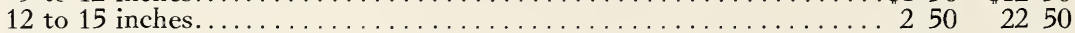

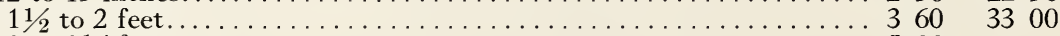

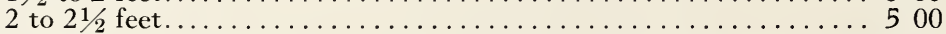

R. maximum. A hardy variety, of magnificent size, making it a wonderfuI plant for mass effects. The Iuxuriant growth of dark green, narrow leaves, 6 to 12 inches long, gives a delightful atmosphere. The light pink or white flowers, $1 \frac{1}{2}$ to 2 inches broad, are borne in large clusters in great abundance in June.

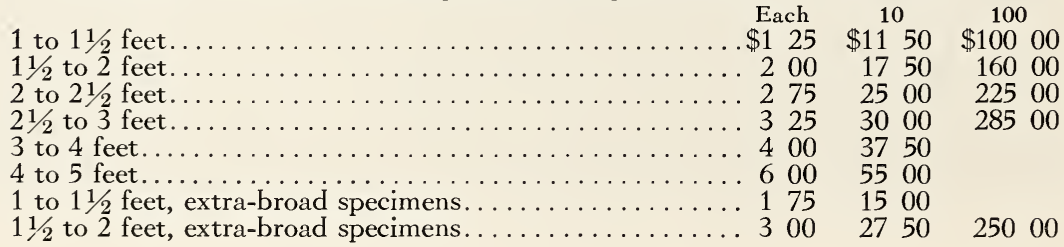




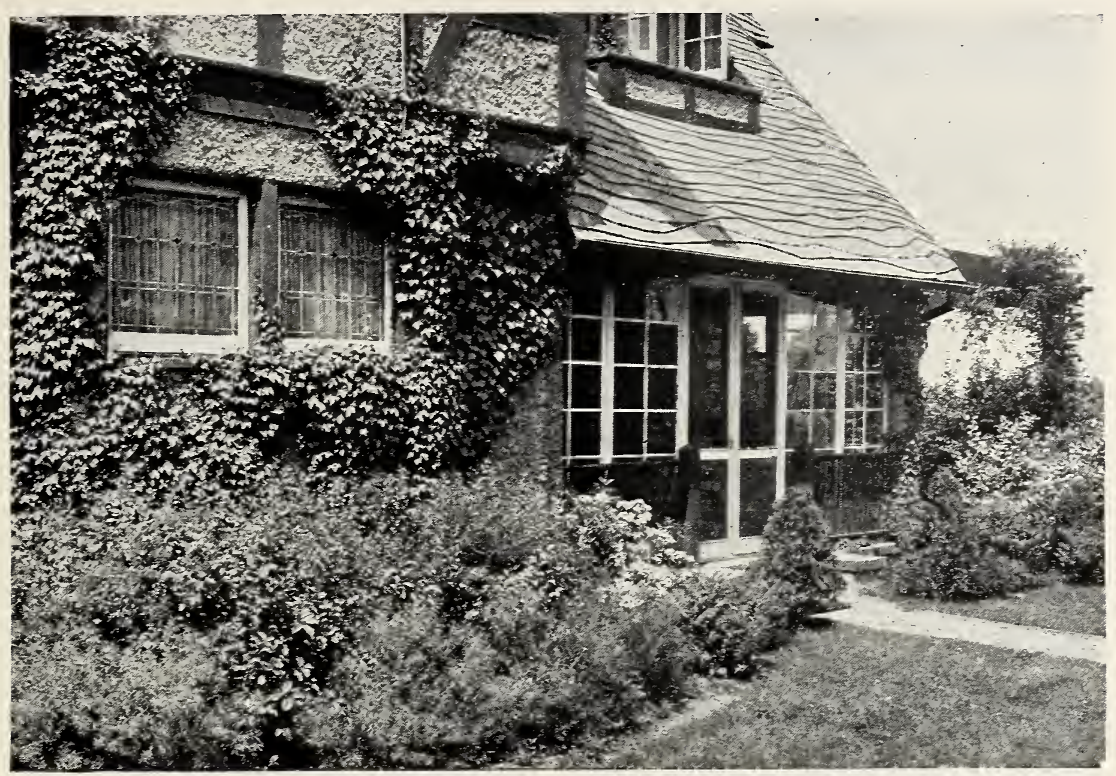

\section{DECIDUOUS SHRUBS}

No matter how beautiful or expensive the home is, it lacks a graceful, artistic appearance if not surrounded by a judiciously planned group of shrubs to give it a setting, to act as a frame to intensify the building's beauty. Native shrubs are ideal plants for this purpose. They are adapted to the climate; they pass through our seasons of intense coId and summer heat, often through sieges of drought, without injury. In fact, only the most unusual conditions experienced once in a century ever cause marked injury. That is why we recommend native shrubs. Moreover, with few exceptions, we believe that they are the most beautifuI of all shrubs in form, in flower, and, in many instances, in fruits.

AII the plants in the heath family here listed-azalea, huckleberry, and blueberryrequire sour soil conditions if they are to thrive. Under the rhododendron section, directions for creating these conditions will be found. Moreover, they will succeed better if each fall a 4 to 6 -inch mulch of leaves is put about the plants and allowed to rot-do not remove in the spring.

Azaleas require more careful handling than ordinary shrubs. I dig these with Iarge balls of earth which are carefully wrapped in burlap before packing to protect them from injury during delivery, and prevent breaking of the ball and roots and drying out of the fibrous roots. Set the plant in the hole where it is to grow, open and remove the burlap, and then fill in with earth.

Of all the native shrubs available for use, I have selected only those which I believe to be the best and which will give the greatest pleasure. From this list it is possible to make a selection of shrubs that will bloom from early spring till frost, so that throughout the greater part of the year there is always something to look forward to. AII are carefully grown, dug, and packed, so as to reach their destination in the finest condition. The prices given are f. o. b. Southwick, and include packing charges. There are no extra charges.

AMELANCHIER canadensis (Downy Service-Berry). Native. In Iate ApriI or early May this small tree- 15 to 30 feet high-is loaded with clusters of small white flowers that appear with, or just before, the leaves. The young leaves, which are silvery white, intensify the beauty of the tree at that time. The quarter-inch maroon-purple fruits are dry and tasteless, and fall early. 2 to 3 feet, 50 cts. each, $\$ 4$ for $10, \$ 30$ per 100 . 


\section{DECIDUOUS SHRUBS - Edward Gillett, Southwick, Mass.}

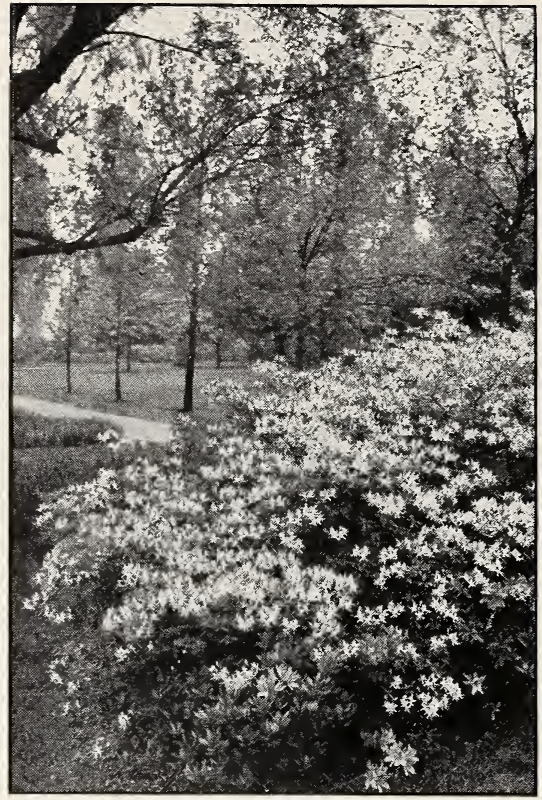

Azalea nudiflora

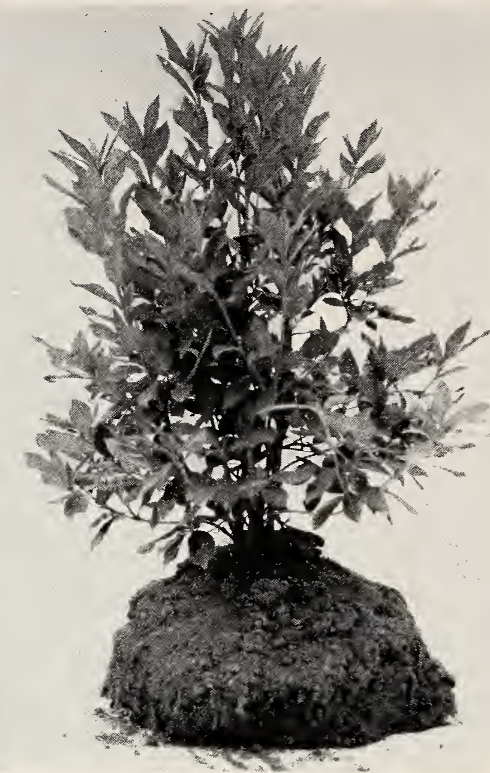

A typical plant of Azalea calendulacea

AZALEA arborescens (Sweet Azalea). Very attractive white, or faintly rose-tinted, fragrant flowers whose beauty is enhanced by the long, bright red filaments of the stamens. The flowers are borne after the foliage appears, and it is one of the most beautiful of all the hardy Azaleas. In sheltered places it often reaches 15

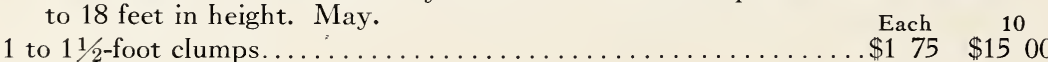

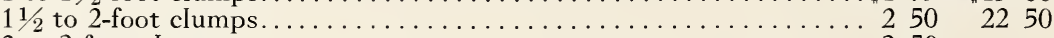

2 to 3 -foot clumps............................... 350

A. calendulacea (Flame Azalea). Probably the most gorgeous of the native Azaleas. From early May until well into the month of June, the plants are literally covered with orange-yellow or flame-red blooms which in size are often 2 inches across. The well-known Ghent Azaleas rarely ecual in brilliancy this native species. Foliage remains good until late fall and breaks in the spring just before the $\begin{array}{llll}\text { blooms appear. } & \text { Each } & 10 & 100\end{array}$

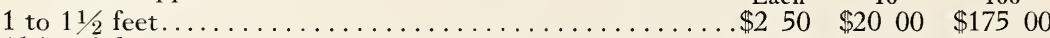

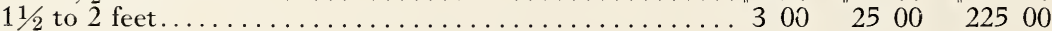

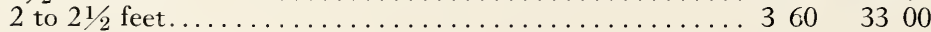

A. canescens (Piedmont Azalea). Rosy pink or whitish trumpet-shaped flowers of great beauty, borne in May before or with the unfolding leaves, fill the air with sweet fragrance. Plant in masses against a dark background to show the flowers to the best advantage.

$$
\text { Each } 10 \quad 100
$$

1 to $1 \frac{1}{2}$ feet............................ \$2 $00 \quad \$ 1750 \quad \$ 15000$

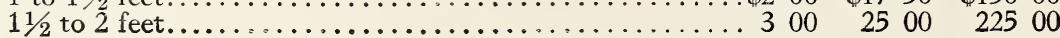

A. nudifiora (Pinxter Bloom). An extremely beautiful Azalea. Rosy pink or whitish blooms, after or before the foliage develops, of strong, sweet fragrance, and borne in great profusion at about the same time as $A$. canescens. Fall foliage assumes attractive shades of orange and bronze. Fine for dry open places. Height 2 to 6 feet.

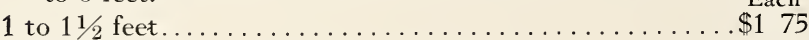

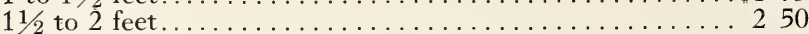

$10 \quad 100$

$11 / 2$ to 2 feet.

300

$\$ 1500 \quad \$ 12500$

$\begin{array}{llll}22 & 50 & 220 & 00\end{array}$ 


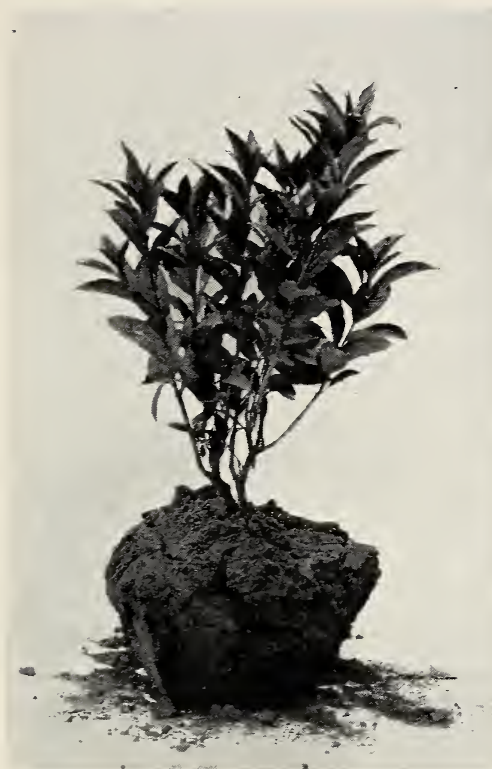

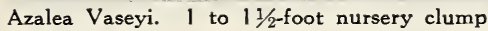

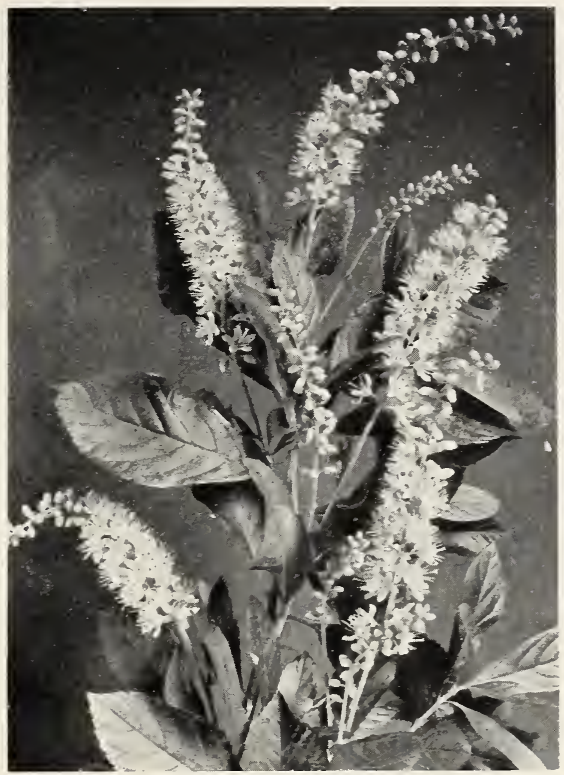

Clethra alnifolia

AZALEA Vaseyi (Pink Shell Azalea). One of the earliest flowering Azaleas, blooming in April, and its glorious pink flowers open before the foliage appears. It is the most beautiful of all the Azaleas, and in delicacy and purity of color is unsurpassed by the flowers of any other plant.

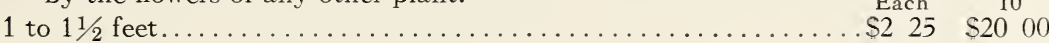

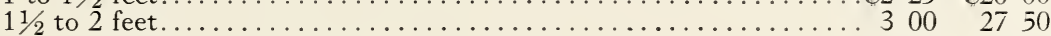

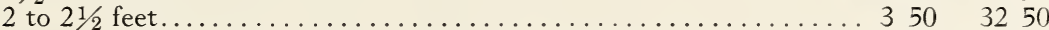

A. viscosa (Swamp Azalea). The last of the Azaleas to flower, nearly all the other shrubs having passed out of bloom when it bears its heavy load of pure white, fragrant flowers, clothed with sticky hairs. Delights in swampy land and borders of lakes and streams. Special prices on quantity lots. Each $10 \quad 100$

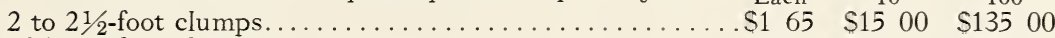

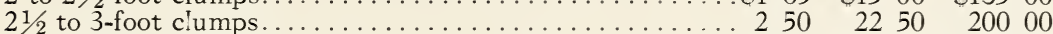

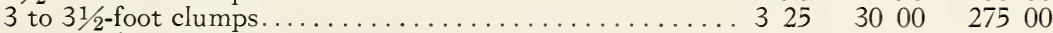

$31 / 2$ to 4 -foot clumps...................... $400 \quad 3750 \quad 35000$

Please note that all Azaleas are dug with ball of earth and wrapped in burlap.

CEANOTHUS americanus (Jersey Tea). A low-spreading shrub, 2 to 3 feet high, with bright green foliage and white flowers in dense panicles in midsummer. Thrives in dry, partially shaded places. $1 \mathrm{fcot}, 40$ cts. each, \$3.50 for 10 .

CLETHRA alnifolia (Summersweet). One of the most delightful of the summer-flowering shrubs, bearing its small, sweetly fragrant, creamy white flowers in narrow pyramidal spikes in July. Height 3 to 10 feet. 1 to $11 / 2$ feet, 40 cts. each, $\$ 3.50$ for 10 .

CORNUS Amomum (Silky Dogwood). The finest shrub to plant at the margins of ponds or in front of groups of trees and taller-growing shrubs. It is rather widespreading, needing 20 feet of room to spread out in, and the purple stems are an attractive winter feature. The fruits, which are bright blue, persist until winter. A good plant for a bird sanctuary, providing nesting places, shelter, and food.
3 to 4 feet.
Each 10 100

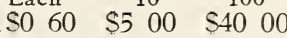




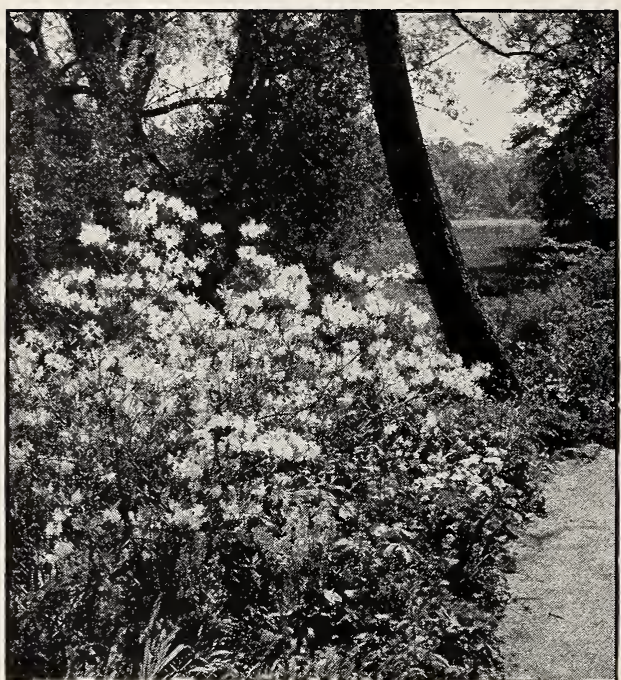

Azalea Vaseyi is adapted to mass plantings in the open or in partly shaded places

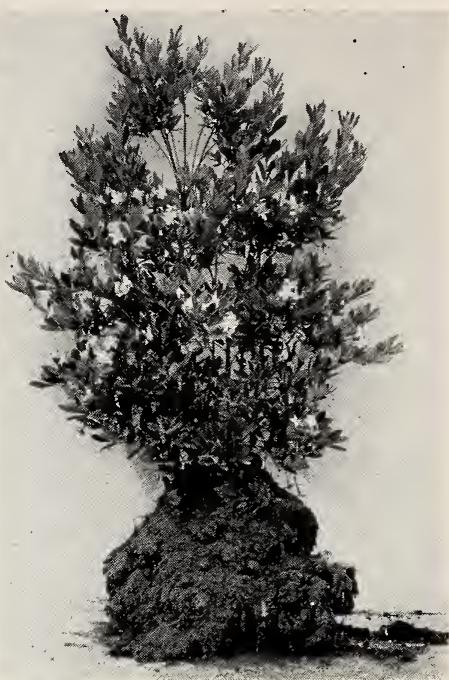

Azalea viscosa taken at random from a shipment of 2 to $2 \frac{1}{2}$-foot grade plants

CORYLUS americana (American Hazlenut). A very attractive, 4 to 8 -foot shrub, with somewhat spreading habit and attractive dark green foliage. It bears an abundance of well-flavored nuts in curiously ruffled husks.

Each

10

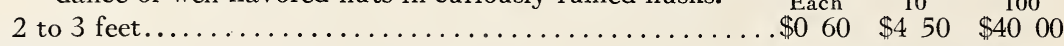

DIERVILLA trifida (Dwarf Bush-Honeysuckle). One of the unusual shrubs, low-growing, spreading, seldom more than 3 feet high, which in June carries a heavy crop of half-inch Iong yellow flowers. $1 \frac{1}{2}$ feet, 30 cts. each, $\$ 2.50$ for $10, \$ 20$ per 100.

HAMAMELIS virginiana (Witch-Hazel). Native. A most unique shrub, covered in the faII with clear yellow flowers, having strap-shaped petals that remain a Iong time. The leaves, which turn a deep golden yellow, drop about the time the flowers appear.

Each
.$\$ 025$

1 to $11 / 2$ feet.

$11 / 2$ to 2 feet.

2 to 3 feet. .
40

60

$\begin{array}{rrrr}\$ 2 & 00 & \$ 17 & 50 \\ 3 & 50 & 27 & 50\end{array}$

350

500

RHODORA canadensis (Rhodora). Native. One of the earliest blooming members of the rhododendron tribe. It blooms so profusely that if planted in masses it produces a sheet of rose and purple color. Hardy to Newfoundland and thrives in swampy Iand. 15 to 18 inches, $\$ 1$ each.

ROSA blanda (Meadow Rose). Native. This is the big single pink Rose of the North. When grown in masses, on banks or in meadows, it gives delightful effects in Iate May and early June. Grows 3 to 5 feet taII, and has reddish purple canes with only a few soft prickles. The heps persist till winter. 2 to 3 feet, 50 cts. each, $\$ 4$ for $10, \$ 30$ per 100 .

RUBUS occidentalis (Common Black Cup). Native. Every bird-lover and conservationist who has waste land or a corner which may be dedicated to a bird sanctuary or a game-refuge should plant this and the two succeeding species. In spring the dense, prickly clusters of half-inch white flowers are followed by edible berries of which the birds are fond. 2 to 3 feet, 30 cts. each, $\$ 2.50$ for 10 .

R. strigosus (Red Raspberry). Native. Slender canes, 3 to 5 feet Iong, with stiff prickles and bright red fruits. 2 to 3 feet, 25 cts. each, $\$ 2$ for 10 .

R. villosus (Blackberry). Native. Long, slender canes that often are bent to the ground under the load of foliage and Iarge Iuscious fruits. Flowers white. 2 to 3 feet, 25 cts. each, $\$ 2$ for 10 . 


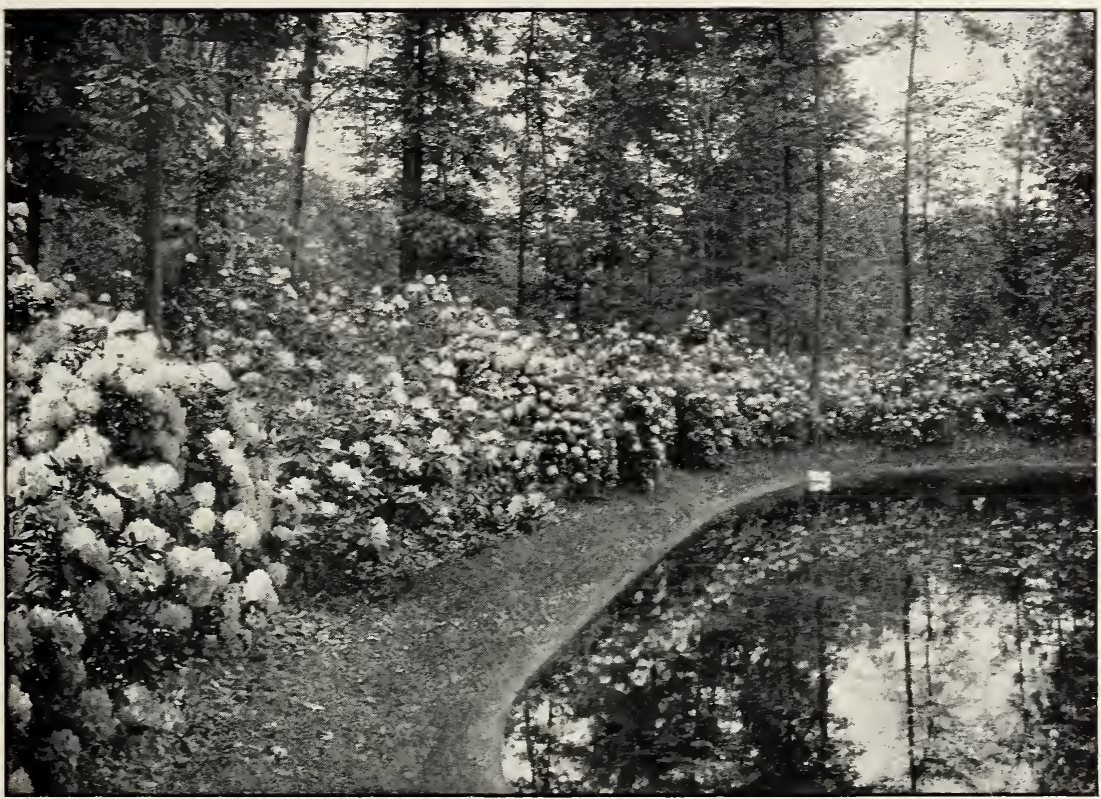

The innate beauty of Rhododendrons is reflected in the pool, which in the original planting is completely surrounded

SAMBUCUS canadensis (American EIder). This is one of the most conspicuous native shrubs. Late in June, the broad, 6 to 8-foot plants are a mass of big, flat heads of white flowers, followed in September by small, black fruits that make delicious jellies. When grown with Rosa lucida, as it does back of the sea-cliffs in Massachusetts, a combination of wonderful beauty is produced. $3 \mathrm{feet}, \bar{j} 0 \mathrm{cts}$. each, $\$ 4$ for 10 .

S. racemosa (European Red EIder). A massive shrub, producing large, flat clusters of yellowish white blooms in spring, followed in mid-summer by $1 / 4$-inch attractive scarlet berries. Height 12 feet. 3 feet, 50 cts. each, \$4 for 10.

SYMPHORICARPOS vulgaris (CoraI Berry). Native. A desirable ground and bankcover in full sun and partial shade. The most prominent feature is the coral-red berries which are so crowded on the stems as to remind one of coral; they persist aII winter. 2 to 3 feet, 50 cts. each, $\$ 4$ for $10, \$ 30$ per 100.

VACCINIUM corymbosum (High-bush Blueberry). Native. Every garden should grow the Blueberry. The small, handsome flowers are followed by an abundance of Iarge-sized, delicious berries. In the late October and early November, the bright scarlet foliage is unsurpassed by any other in the whole list of ornamental plants. Like all plants belonging to the heath family, it abhors lime; that has been the drawback to its cultivation, for making acid soils was not understood. Now, however, sour soils are easily produced, as explained under rhododendron culture on page 30 . There is no reason why every garden owner should not enjoy the fruits and foliage of this very beautiful native shrub. Each $10 \quad 100$

1 to $11 / 2$-foot plants, balled and burlaped..............\$0 $60 \quad \$ 5 \quad 50 \quad \$ 50 \quad 00$

$11 / 2$ to 2 -foot plants, balled and burlaped.................. $100 \quad 8 \quad 50 \quad 7500$

2 to $2 \frac{1}{2}$-foot plants, balled and burlaped..................... $150 \quad 1250 \quad 10000$

VIBURNUM acerifolium (Mapleleaf Viburnum). Native. A desirable shrub growing 3 to 5 feet tall, with maple-like leaves and 2 to 3 -inch, flat-topped clusters of creamy white flowers. The twigs turn dark purple in the fall; red fruits, turning purple-black, remain till early winter. Fine for mass effects.
1 to $11 / 2$ feet.
Each
2 to 3 feet.
\$0 50
10 
Viburnum cassinoides (Withe-Rod). Native. One of the most beautiful shrubs, combining, as it does, so much beauty of foliage, flowers, and fruit. It grows 12 feet high, and has thick, dark green, lustrous foliage. The large, convex clusters of creamy white flowers are followed by pea-sized white fruits that turn to pink and finally blue, often all three colors present at once. $\quad$ Each $10 \quad 100$

$11 / 2$ to 2 feet............................... \$0 35 \$3 $00 \quad \$ 2500$

2 to 3 feet.............................. $50 \quad 400 \quad 3000$

V. pubescens (Downy Viburnum). Native. No Viburnum is more profuse in its blooms, it being literally covered with flat-topped heads of white flowers, the cluster of fertile flowers being framed by a ring of showy sterile ones. Black fruits in September. Grows 12 feet high. $\quad$ Each $10 \quad 100$ $11 / 2$ to 2 feet, bush plants ..................... $\$ 075 \$ \$ 6 \quad 50 \quad \$ 5500$

2 to $2 \frac{1}{2}$ feet, specimens..................... $100 \quad 850$

ZANTHORHIZA apiifolia (Yellow-root). Native. Extremely good plant for groundcover under trees and on banks and rough ground, producing a soft, fern-like effect of great beauty. It has bright green leaves and drooping, compound racemes of star-shaped, brown-purple flowers. Roots and wood of stems yellow. Height 1 to 2 feet. 6 to 8 inches, 25 cts. each, $\$ 2$ for $10, \$ 12$ per 100 .

\section{SHRUBS DESIRABLE FOR A WET PLACE}

These can be planted where it is quite wet, or they will grow in any moist garden soil. Nost of them are desirable for growing in masses.

Andromeda polifolia, 1 foot. Azalea viscosa, 4 to 10 feet. Cassandra calyculata, 1 foot. Gaylussacia resinosa, 2 feet.

Kalmia glauca, 2 feet. Ledum latifolium, 1 foot. Rhodora canadensis, 2 feet. Vaccinium corymbosum, 5 to 10 feet.

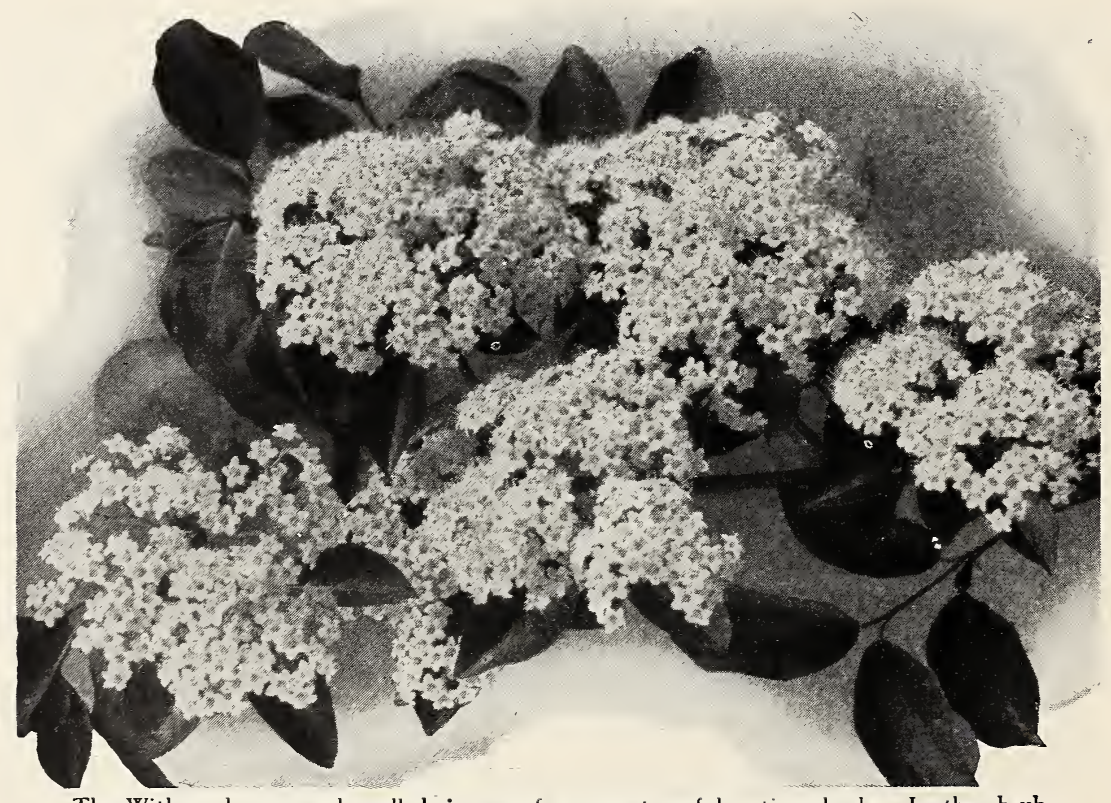

The Withe-rod, commonly called, is one of our most useful native shrubs. In the shrub border, at the edge of a woodland, and in large groups it is exceedingly effective

On page 26 I refer to Daphne Cneorum. The specimens are superb plants-in fact, I consider them the best plants I have ever offered 


\title{
SPECIAL PRICE-LIST OF
}

\section{Collected Kalmias, Rhododendrons Andromeda, Azaleas, Leucothoë}

\author{
SHIPPED DIRECT FROM COLLECTING FIELDS \\ IN THE SOUTH
}

These prices must not be confused with those given on pages 26 to 30 , which are for less than carload lots.

To landscape architects and nurserymen who use special grades of collected stock, we shall be glad to quote quantity prices.

\section{Prices}

I am listing two sets of prices, one covering stock shipped in carload lots, another covering small shipments sent in cases. The prices on small shipments include the cases and material used in packing, together with all other incidental costs, including delivery to the transportation company at point of shipment.

\section{Shipping Season}

I can begin shipping about March I and continue until the middle of May.

\section{Special Grades}

I can furnish special sizes and grades of Rhododendrons and Laurel to meet any requirements. Quotations covering special needs will be made upon application.

\section{Combination Carloads}

To those who wish combination carloads consisting of Broad-leaved Evergreens, Azaleas, Ferns, and Herbaceous Plants, I am pleased to offer a special service. By special arrangement I can assemble all of the items listed in this special catalogue, making shipment in the same car from the same shipping-point. This I feel sure will be welcome news to many who desire to have all of their plant material arrive at the same time from the same source. There is no additional charge for this special service. The prices listed in this special catalogue will apply.

\section{Number of Plants to Carload}

Following is a schedule showing the number of plants in the various sizes and varieties which make up a minimum weight car of 16,000 pounds. It is always well to have the weight run over the minimum, and, as a rule, a larger quantity than that shown in the schedule following can be easily placed in a car.

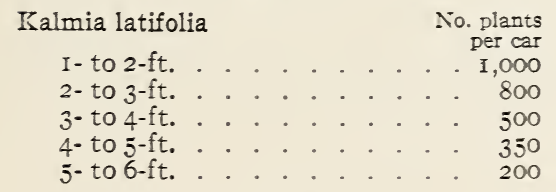

Rhododendron carolinianum

I - to $2-f t$.

2- to 3 -ft.

3- to 4-ft.
Rhododendron catawbiense

$\mathrm{I}$ - to $2-\mathrm{ft}$.

2- to 3 -ft.

3- to 4 -ft.

No. planis per car

I, 000

750

400

Rhododendron maximum

$I=$ to $2-\mathrm{ft}$.

2 - to $3-\mathrm{ft}$.

3- to 4 -ft.

4- to 5-ft.

5-to 7 - $\mathrm{ft}$. 


\section{Schedule of Prices Covering Less than Carload Shipments}

(Including careful packing and delivery to the transportation company at collecting point.)

\section{Kalmia latifolia}

I- to $2-\mathrm{ft}$.

\$1 I0 oo

2- to 3 - $\mathrm{ft}$.

3- to 4 -ft.

12 50

. 1750

Leucothoë Catesbæi. I - to 2-ft. . . Iо oo 2 - to 3 -ft. . . . . . . . . . 1250 3- to 4 -ft. . . . . . . . . . . I 750

Andromeda floribunda. I- to $2-\mathrm{ft}$. . I 5 oo 2 - to 3 -ft. . . . . . . . 2250

Azalea lutea. $\mathrm{I}$ - to $2-\mathrm{ft}$. . . . . 850 2- to 3 -ft. . . . . . . 15 oo 3- to 4 -ft. . . . . . . 2000

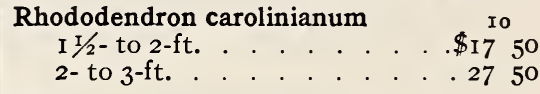

Rhododendron carolinianum

I $1 / 2$ - to 2 -ft. . . . . . . . . \$17 50

2 - to 3 -ft. . . . . . . . . . . 2750

\section{Rhododendron catawbiense}

I $1 / 2-$ to 2 -ft.

I 5 oo

2- to 3 - $\mathrm{ft}$.

2500

\section{Rhododendron maximum}

$\mathrm{I} \mathrm{I} / 2$ - to 2 -ft. . . . . . . . 850

2- to 3 -ft. . . . . . . I 5 oo

3 - to 4 -ft. . . . . . . . 20 oo

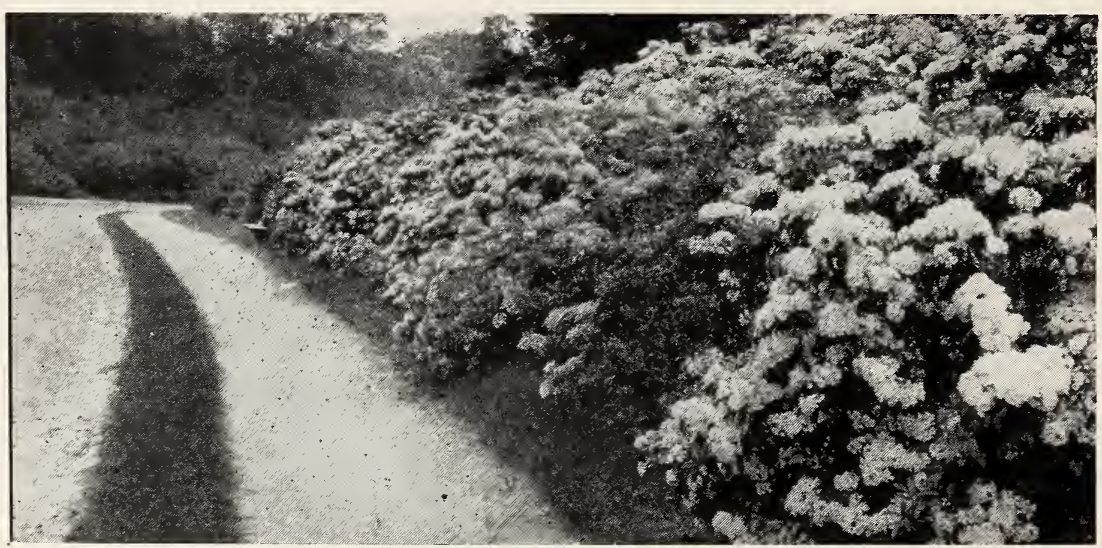

Planting of Kalmia latifolia

\section{Kalmia latifolia (Calico Bush; Mountain Laurel)}

My source for collecting Mountain Laurel is unsurpassed. Orders for the largest requirements can be properly executed. The stock coming from these collecting fields digs with exceptionally fine balls of earth. None of our native broad-leaved evergreens surpass in beauty this representative of the Heath family. Its white flowers, delicately tinged with pink, come forth in great profusion during the spring months, and, when masses are planted in the open sun on the hillside, can be seen for miles around. Colonies of this beautiful evergreen shrub when once established increase in beauty from year to year, eventually developing into grand old landmarks.

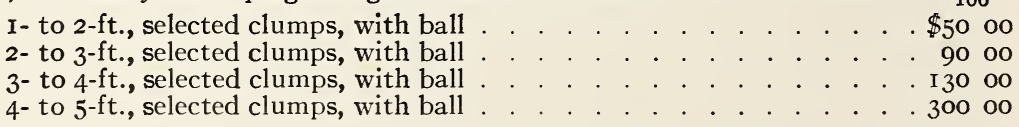

\section{Leucothoë Catesbæi (Drooping Andromeda)}

This drooping evergreen shrub produces an abundance of delicate white flowers in the spring. It is especially useful for planting along streams, in the meadow, or at the edge of a rhododendron bed. When planted as an individual specimen it develops into a very bushy, compact plant. In the autumn the foliage turns a deep bronze, giving it a distinctive appearance.

I - to 2 -ft., selected clumps, with ball 


\section{Rhododendron carolinianum}

I am able to offer this rare and most beautiful of our American Rhododendrons in any quantity, size, or grade. This variety, coming from very high altitudes, is extremely hardy, and, when transplanted to sections in the North, stands exposure extremely well. No other native variety rivals the Carolinianum in floral display; on clumps 3 feet high oftentimes as many as 200 flower-buds will be set. The flowers are pure pink, having no trace of magenta. The foliage is much smaller than that of Maximum or Catawbiense, and when this variety is planted in the open sun, it forms compact, symmetrical specimens.

I $1 / 2$ - to 2 -ft., strong clumps, with ball

I00
$\$ 4000$

2- to 3 -ft., strong clumps, with ball.

20000

3- to 4-ft., strong clumps, with ball

45000

\section{Rhododendron catawbiense (Catawba Rhododendron)}

I am pleased to announce that I have a far superior grade to offer this season in this variety. As a rule, Catawbiense does not come in as compact, leafy specimen as does Maximum. Those ordering early can depend upon receiving fine stock of this rare variety. The flower clusters are very large and the flowers are a bright rosy purple. It blooms earlier than Maximum. This variety stands an open sunny situation extremely well and will produce a far larger amount of blooms there.

I $1 / 2$ - to 2 -ft., selected clumps, with ball

$\$ 12500$

2- to 3 -ft., selected clumps, with ball

220 00

3- to 4-ft., selected clumps, with ball

450 oo

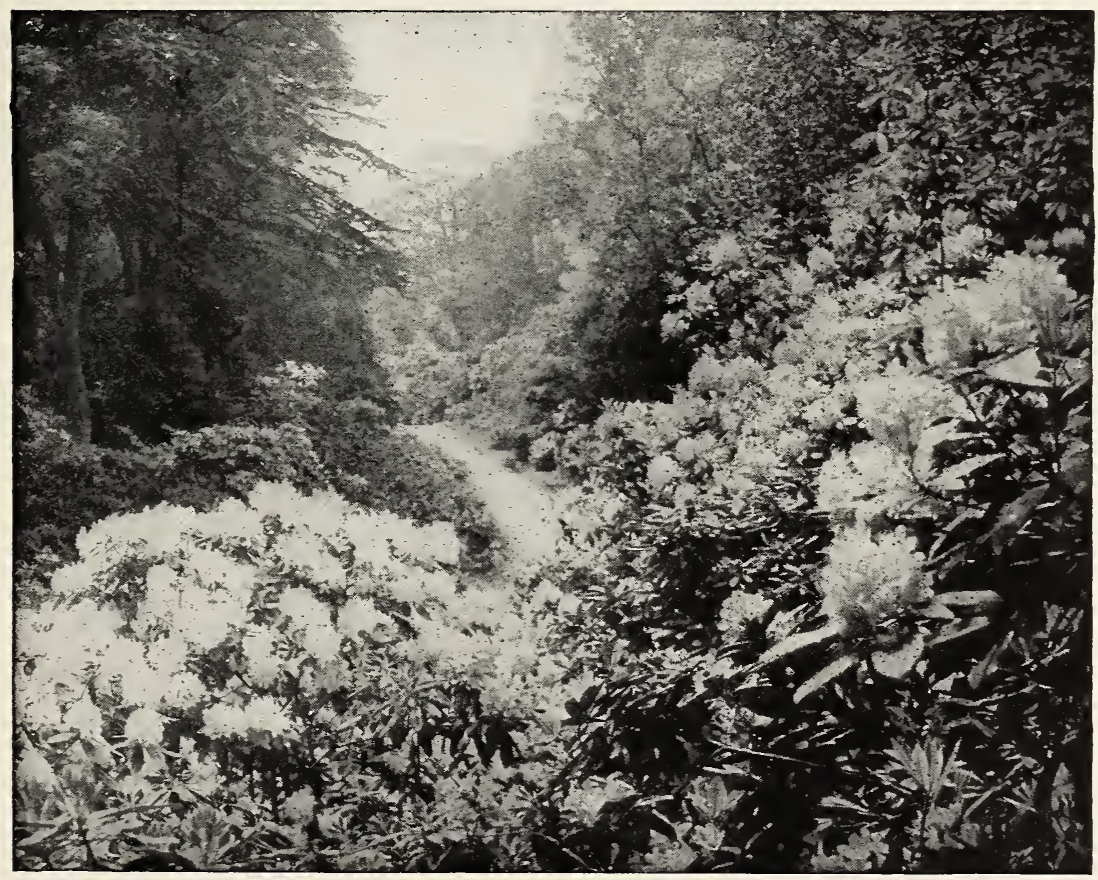

Rhododendron catawbiense

\section{Acid Humus from Peat Beds}

To those who live in a section where acid humus cannot be advantageously obtained, I am pleased to offer special soil, shipped direct from the bogs of New Jersey, at the following prices: Bulk carload, $\$ 9$ per ton; less than carload, put up in 100-lb. bags, $\$ 20$ per ton; five 100-1b. sacks, \$6; all f.o.b. shipping-point. 


\section{Rhododendron maximum (Rose Bay; Great Laure1)}

No order for Rhododendron maximum is toolarge for me to supply in excellent quality material. The collecting fields where the stock is dug are very extensive, comprising hundreds of thousands of specimen plants. This is the variety that is used extensively in park developments and on large estates. The flowers are white to pink, coming late in June or the first part of July.

I00

I $1 / 2$ - to 2 -ft., selected clumps, with ball . . . . . . . . . . . . . . . \$60 00

2- to 3 -ft., selected clumps, with ball . . . . . . . . . . . 9000

3- to 4 -ft., selected clumps, with ball . . . . . . . . . . . I50 oo

4- to 5 -ft., selected clumps, with ball . . . . . . . . . . . . 35000

5- to 7 -ft., selected clumps, with ball . . . . . . . . . . 500 o0

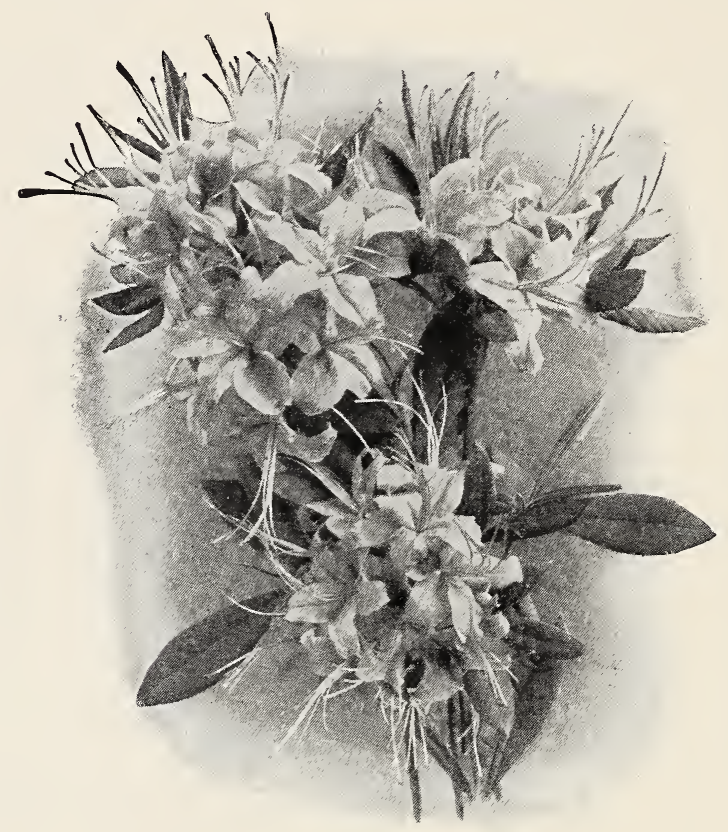

Flame Azalea

\section{Azaleas}

No woodland development where rhododendrons and laurel are used extensively is complete without the introduction of the native Azalea. Azalea lutea (Flame Azalea) is especially recommended in that it is a free bloomer and produces a variety of color. The prevailing color is bright orange. These, if planted in locations where they receive the sun during part of the day, will produce far more bloom than when introduced in the woodland where the shade is quite dense.

\section{Azalea 1utea (Flame Azalea)}

I- to 2 -ft., selected clumps, with ball . . . . . . . . . . . . \$6o oo

2- to 3 -ft., selected clumps, with ball . . . . . . . . . . . . . . Ioo oo

3- to 4 -ft., selected clumps, with ball . . . . . . . . . . . . . . I 80 oo 


\section{INDEX}

\begin{tabular}{|c|c|c|c|}
\hline PAGE & PAGE & & \\
\hline$\ldots \ldots 2 \mathrm{I}$ & Cornus. . . . . . I2, 33 & Ledum. & Rosa. . \\
\hline ....10 & Corylus. & Leek, House........ I9 & Rose. \\
\hline Adiantum. & Cowslip........... 6 & Leucothoe......27,38 & Rose Bay. . \\
\hline Aletris.... & Cranberry $\ldots \ldots \ldots 22$ & Lilium......... I 5,16 & Rubus........ \\
\hline Amelanchier........3 & Crane's Bill, Wild... I4 & Lily $\ldots \ldots \ldots \ldots \ldots$ is, 6 & Rush......... \\
\hline Ampelopsis........24 & Cress, Water. . . . . . 24 & Lily, Water ......24 & Sambụcus..... \\
\hline Andromeda......26, 38 & Cress, Rock. . . . . . . . Io & Lily-of-the-Valley . . . I 2 & Sanguinaria....... I 8 \\
\hline Anemone........... Iо & Cypripedium......23 & Lily-of-the-V a li e y & Sarracenia.........22 \\
\hline Anemone, Rue...... ig & Cystopteris....... 4 & Shrub........26 & Saxifraga.... \\
\hline Anțennaria......... & Daphne..... & Limnanthemum....24 & Scirpus $\ldots . .$. \\
\hline Apios..........24 & Defphinium. & Lobelia........... 6 & Sedge, Marsh. \\
\hline Apple, May ........ & Dentaria......... & Lupine........... . I6 & Sedum........ \\
\hline Aquatic Plants.....24 & Dianthus........... & Lupinus............ 6 & Selaginella.... \\
\hline quilegia.......... 10 & Dicentra.... & Lychnis..... & Sempervivum........ I9 \\
\hline rabis.......... & Dicksonia... & Lycopodium. & Service-berry .......3 I \\
\hline rborvitæ.........2; & Diervilla... & Lysimachia... & Shin Leaf..... \\
\hline rrbutus, Trailing. . .24 & Digitalis... & Lythrum.... & Shooting Star... \\
\hline Arctostaphylos......24 & Diplopappus........13 & Mandrake........ I & Shortia.......... \\
\hline renaria.......... i i & Dodecatheon.......13 & Marigold, Marsh.... 2 I & Shrubs, Decidu- \\
\hline Arisæma $\ldots . . \ldots \ldots$ I I & Dogwood.... & Mtadow Rue... . . . I9 & ous.......... $3^{1-36}$ \\
\hline Arum, Water......24 & Drosera.... & Menyanthes.......22 & Shrubs, Evergreen 26-30 \\
\hline isarum.......... II & Dutchman's Breechesi 3 & Mertensia......... 6 & Shrubs for Wet Places36 \\
\hline Asclepias........... I I & Elder........ . . . & Mitchella.......... I & Smilacina. . \\
\hline pidium......... 3 & Epigæa..........24 & Mitella........ & Snake Head. \\
\hline splenium......... 4 & Erysimum.......... & Miterwort, False.... I9 & Snakeroot.... I I, I 2, I 4 \\
\hline Aster. . . . . . II $12=20$ & thronium.......13 & Moccasin Flower....23 & Solidago .......... I9 \\
\hline Azalea...... 32, 3j, $\div 0$ & Eupatorium. & Moneywort......... 6 & Solomon's Seal. \\
\hline eberry......... is & $\ldots \ldots$ 10 & s, Club....... 6 & Solomon's Seal, Falseig \\
\hline Baptisia ......... & s, Collections of. 7 & otis.......... & edwell.........20 \\
\hline Bean, Buck . . . . . . 22 & Ferns, Hardy . . . . . 2-7 & urtium.......24 & iderwort.... \\
\hline Bean, Wild........24 & , Sweet.......2 I & $\operatorname{ta} \ldots \ldots \ldots \ldots \mathrm{x}^{-}$ & Spring Beauty...... I 2 \\
\hline berry .........24 & ting Heart.....24 & …222 & Stonecrop...... 18, 19 \\
\hline p's Cap........ is & et $-m e-n o t \ldots \ldots$. & Night-Shade....... 20 & Summersweet......33 \\
\hline Bittersweet.......24 & Foxglove......... 13 & Nuphar.......... . 24 & Sundew. \\
\hline kberry..... .2:34 & $\cdots \cdots 1_{4}$ & phæa.........24 & Sweet William...... I3 \\
\hline odroot.......... I3 & $\ldots \ldots{ }_{4}$ & ... 5 & rpos......35 \\
\hline berry......... 35 & .....14 & glossum & Hor....28 \\
\hline Bluet.......... $1=, 15$ & $\ldots \ldots I_{4}$ & Orchids, Native.....23 & $\ldots \ldots \ldots 33$ \\
\hline Plants......2:, 22 & $\ldots$ I $_{4}$ & $5 \ldots \ldots \ldots \ldots 23$ & Thalictru \\
\hline rychium & $\ldots \ldots 1_{4}$ & Osm & Thoroughwort...... I4 \\
\hline . 6 & ..... 17 & $\ldots 28$ & Thuya............ \\
\hline$\ldots 24$ & ger, Wild. & , Horned. & Thyme.......... \\
\hline ed......11 & ...... 19 & $\ldots 17$ & mus. . . . . . . 19 \\
\hline ico Bush........38 & $\ldots \ldots 13$ & idge Berry. & Tiarella.......... I \\
\hline$\ldots \ldots \ldots \ldots 2 \mathrm{I}$ & $\ldots \ldots 23$ & Flower....... Io & Toothwort. \\
\hline$\ldots \ldots 26$ & , Pigeon.....24 & Pella & Tradescantia......20 \\
\hline$\ldots \ldots 21$ & of Parnassus. . it & $\ldots 24$ & Trees, Evergreen.....25 \\
\hline$\ldots .12$ & Star........ I & $\ldots 13$ & Trillium . . . . . \\
\hline & $\ldots \ldots \ldots 23$ & ials, Hardy I0-2I & Trumpet-Leaf . . . . . 22 \\
\hline & $\ldots \ldots 34$ & kle........ & Trumpet Weed..... I 4 \\
\hline r. . . I6 & & $\ldots ;, 6$ & Tsuga.......... \\
\hline ndra..........26 & ....25 & Phlox & Tunica.... \\
\hline$\ldots \ldots \ldots \ldots \ldots$, & $\ldots \ldots=2$ & Pickerel Weed & Turnip, Wild.... \\
\hline$\ldots 22$ & $\ldots 25$ & & Typha........22 \\
\hline$\ldots 12$ & & Pin & Uvularia.........20 \\
\hline$\ldots 33$ & Robert. & e, Prince's........ I 2 & Vaccinium.....22, 3 \\
\hline$\ldots .25$ & $\ldots \ldots$ is & $\ldots \ldots \ldots \ldots \mathrm{I}_{3}, \mathrm{I}^{-}$ & $\ldots \ldots \ldots 22$ \\
\hline$\ldots .24$ & $\ldots \ldots$ is & Plant.......22 & Vernonia.. \\
\hline$\ldots \ldots 12$ & .....34 & in, Rattlesnake 23 & Veronica...... \\
\hline & $\ldots \ldots$ is & hyllum........ I7 & Viburnum......35,36 \\
\hline$\ldots .26$ & $\ldots \ldots 1 s$ & $2 \ldots \ldots \ldots \ldots 23$ & Vinca............ \\
\hline$\ldots 12$ & $\ldots \ldots$ is & Ia $\ldots . . .$. & Vines and Creepers. . 24 \\
\hline . I 2 & & 17 & Viola........20, 2 I \\
\hline$\ldots 12$ & Indigo, Wild......... I 2 & . I 7 & Violet. . . . . . \\
\hline zefoil... & Inkberry........... & odium.... & Virgin's Bower...... 24 \\
\hline$\ldots \ldots 12$ & $\cdots 15,22$ & $\ldots 24$ & Virginia Creeper. . . .24 \\
\hline atis..... & ...220 & $\ldots 17$ & is............ \\
\hline$\cdots 33$ & nd....... I 7 & $\ldots 18$ & Water Shield. . . . . . 24 \\
\hline$\ldots$ I 2 & Jack-in-the-Pulpit. . . I I & $\ldots 18$ & Windflower......... ro \\
\hline h, Blue.. & Joe Pye Weed....... I4 & & Wintergreen... \\
\hline ..... 10 & Junçus...........22 & $\ldots 18$ & n-Hazel..... \\
\hline .... 10 & Juniper . . . . . . . . 25 & Raspberry........ 34 & Withe-rod... \\
\hline vallaria.. & Juniperus. . . . . . 25 & Rhododendrons.... . . & Woodsia. \\
\hline & Kalmia $\ldots \ldots \ldots 2^{-}, 34$ & $29,30,39,40$ & Woodwardia....... 6 \\
\hline I. . . . . . & Lady's Slipper......23 & Rhodora..........34 ${ }^{34}$ & $\cdots 36$ \\
\hline Corn, Squirrel...... I3 & & & Zanthorhiza.. \\
\hline
\end{tabular}

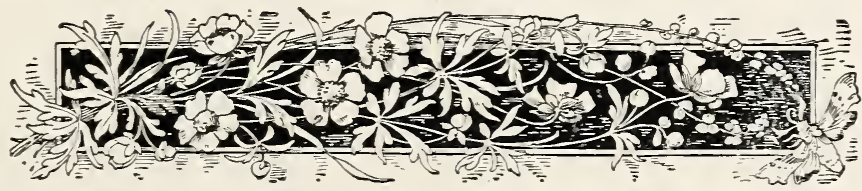




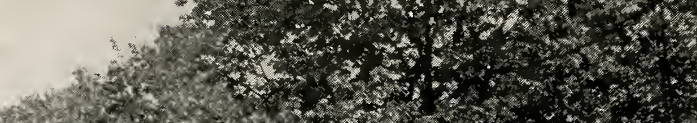

\section{Southivice, Massachusetts 1878-1927}
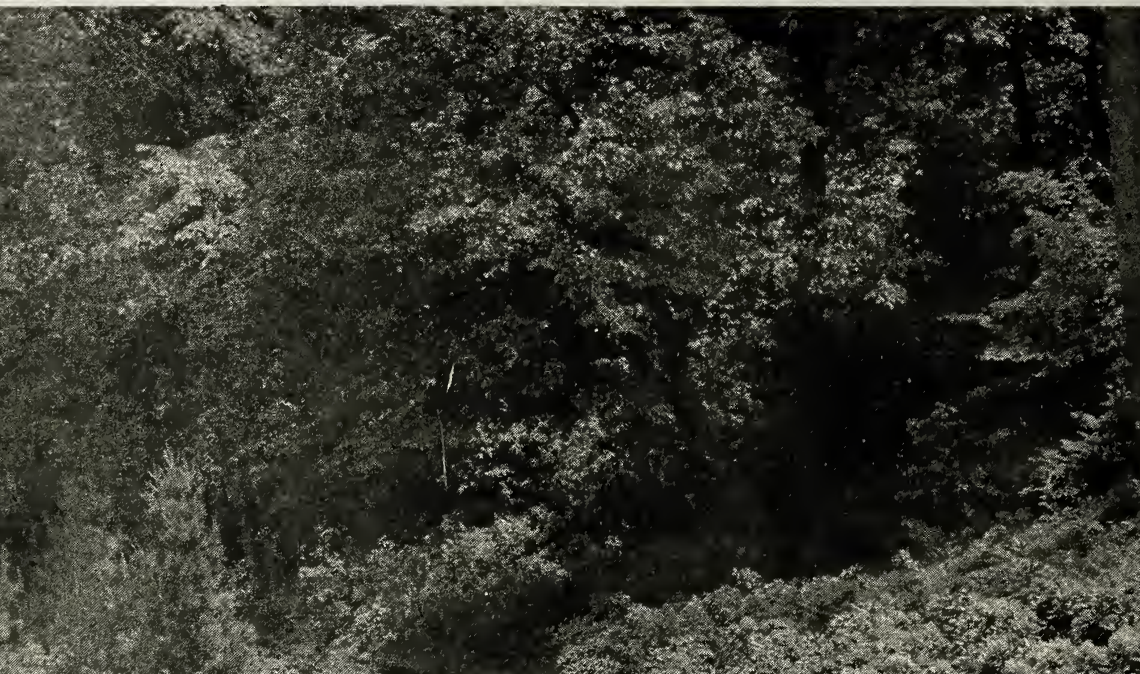